Ks. Józer Wolczański

\title{
SIOSTRY BARBARY ŻULIŃSKIEJ CR WSPOMNIENIA O ARCYBISKUPIE JÓZEFIE TEODOROWICZU
}

\section{WPROWADZENIE}

Przypadająca 4 XII 2008 r. pięćdziesiąta rocznica śmierci pasterza ormiańskokatolickiej archidiecezji lwowskiej abp. Józefa Teodorowicza ${ }^{1}$ stwarza dobrą okazję do spojrzenia oczyma świadków na jego osobę i dokonania. Jednym $z$ nich jest s. Barbara Żulińska, zmartwychwstanka, blisko związana $z$ ormiańskim hierarchą zarówno pracą w tym samym środowisku społeczno-religijnym (Lwów), głęboką fascynacją jego osobowością i misją publiczną, jak również funkcją zaufanej sekretarki, a nawet pierwszej krytycznej recenzentki literackich utworów jego pióra. Wszechstronnie wykształcona, niezależna w myśleniu, sama parająca się czynnie

\footnotetext{
${ }^{1}$ Teodorowicz Józef Teofil (1864-1938), święcenia kapłańskie w 1887 r. we Lwowie w obrządku ormiańskokatolickim, pracę duszpasterską pełnił kolejno przy katedrze we Lwowie, w par. Niepokalanego Poczęcia NMP w Stanisławowie, 1890-1897 proboszcz par. Brzeżany, 1897-1901 kanonik gremialny Kapituły Katedralnej we Lwowie, 1901-1938 arcybiskup lwowski. Już na placówkach duszpasterskich dał się poznać jako dobry organizator i animator w dziedzinie akcji katolicko-społecznej; w 1897 r. zainicjował edycje „Ruchu Katolickiego” i w 1900 r. „Przedświtu”, udzielał się w licznych organizacjach dobroczynnych. W latach 1902-1918 należał do Izby Panów w Wiedniu, 1902-1914 członek Sejmu Galicyjskiego oraz Rady Szkolnej Krajowej, 1919-1922 posel do Sejmu Ustawodawczego, w 1922 r. otrzymał mandat do senatu, ale wkrótce zrzekł się go na polecenie Stalicy Apostolskiej. Uczestniczył w pracy Episkopatu Polski, wchodząc od 1919 r. w skład Komitetu Biskupów, od 1928 r. do Komisji Prawnej, 1928-1936 przewodnicząc Komisji Prasowej i Duszpasterskicj. Był związany ideowo z obozem Narodowej Demokracji, choć po 1928 r. owa współpraca rozluźniła się. Zasłynął jako znakomity orator, kaznodzieja i konferencjonista porównywany do ks. Piotra Skargi. Zajmował się nadto pracą pisarską, publikując kilka tomów biografii Chrystusa, rozważania medytacyjne oraz prace z zakresu teologii mistycznej. Posiadal Krzyż Wielki Orderu Odrodzenia Polski oraz doktorat honoris causa Uniwersytetu Lwowskiego. Zmarł 4 XII 1938 r. we Lwowie, zostal pochowany na Cmentarzu Obrońców Lwowa, ale na początku lat $70 . \mathrm{XX}$ w. w dobie profanacji nekropollii przez władze sowieckie potajemnie przeniesiono jego zwłoki do grobowca rodziny Klosowskich na Cmentarzu Lyczakowskim we Lwowie, gdzie spoczywają do dziś. Wszelkie próby ekshumacji drogą legalną po 1991 r. nie przyniosły rezultatu. K. Krasowski, Biskupi katoliccy II Rzeczypospolitej. Slownik biograficzny, Poznań 1996, s. 291-298; informacje własne autora.
} 
pisarstwem, pozostawiła na piśmie po śmierci abp. Teodorowicza kilka szkiców portretowych swego przewodnika duchowego, mistyka, męża stanu, patrioty, znakomitego oratora i cenionego pisarza religijnego. Zanim spojrzymy na ciężar gatunkowy owych wspomnien, warto poświęcić słów kilka ich autorce.

Późniejsza zakonnica przyszła na świat 19 X 1881 r. we Lwowie w rodzinie dr. Józefa Żulińskiego i Łucji z Grossów. Była najstarszy dzieckiem spośród pięciorga rodzeństwa. Matka zajmowała się wychowaniem dzieci oraz prowadzeniem domu, ojciec pełnił funkcję nauczyciela i dyrektora Państwowego Żeńskiego Seminarium Nauczycielskiego. Patriotyczne tradycje obojga rodziców wyniesione $z$ ich domów rodzinnych, glęboka religijność, a jeszcze bardziej pasja społecznikowska ojca, niezwykle mocno oddziaływały na formację duchowo-intelektualną dzieci, w tym Barbary ${ }^{2}$. Edukację na szczeblu podstawowym rozpoczęła w szkole ss. Benedyktynek łacińskich we Lwowie, po czym idąc w ślady ojca kontynuowała naukę w Seminarium Nauczycielskim tamże. Studia wyższe odbywała na Uniwersytecie Lwowskim w zakresie nauk humanistycznych ${ }^{3}$. Zdobyta wiedza, poparta talentem pedagogicznym, ułatwiła jej objęcie funkcji dyrektorki Seminarium dla Przedszkolanek we Lwowie. Realizując głos powołania zakonnego, wstąpiła w 1914 r. do Zgromadzenia ss. Zmartwychwstanek, składając dwa lata później śluby. Bezpośrednio po tym fakcie powierzono jej na okres roku 1916-1917 obowiązki kierownicze w Zakładzie św. Anny dla dziewcząt w Warszawie. Po powrocie do Lwowa w 1917 r., została przełożoną domu ss. Zmartwychwstanek, a w latach 1919-1930 pełniła funkcję dyrektorki Państwowego Seminarium Ochroniarskiego. Kolejnych dziewięć lat (1930-1939) spędziła na stanowisku wykładowcy w Seminarium Pedagogicznym ss. Zmartwychwstanek w Warszawie, pełniąc zarazem od 1934 r. do wybuchu II wojny światowej obowiązki dyrektorki tej instytucji. Po II wojnie światowej zajęła się procesem organizowania nauki religii w Radomiu, jak również współpracowała $\mathrm{z}$ zespołem przygotowującym programy katechetyczne. Ostatnie lata życia spędziła w Częstochowie zajmując się nauczaniem oraz pracą pisarską. Zmarła 28 I 1962 r. w Częstochowie. Pozostawiła po sobie bogatą spuściznę pisarską z dziedziny biografistyki, pedagogiki katolickiej, literatury religijnej"

Wychowana w tradycji Kościola rzymskokatolickiego, Żulińska - podobnie jak wielu jej współczesnych mieszkańców nie tylko Lwowa ale też innych miast polskich - uległa głębokiej fascynacji osobowością i postawą pasterza archidiecezji lwowskiej obrządku ormiańskokatolickiego Józefa Teodorowicza. Osobiście zetknęła się z nim w roku 1902 we Lwowie mając 21 lat, a więc u początków jego posługi na stolcu arcybiskupów lwowskich. Ale zarówno wcześniej, jak i po tym

'Archiwum Zgromadzenia ss. Zmartwychwstanek w Kętach (dalej cyt.: AZK), B. Żulińska, Wspomnienia lwowskie, bmr, s. 1-60, mps, sygn. K III Żul. XXXIV.

"Archiwum Autora w Krakowie (dalej cyt.: AAK), Relacja pisemna s. Tarsylli Krymowskiej CR, Kęty 25 LX 2998 r., bsygn.

"B. Micewski, Żulińska Barbara Teresa, [w:] Stownik Polskich Teologów Katolickich (dalej cyt.: SPTKi. L ־ red. L. Grzebień, Warszawa 1983, s. 513-518. 
fakcie, wielokrotnie uczestniczyła w uroczystościach $\mathrm{z}$ udziałem hierarchy, wsłuchując się $z$ entuzjazmem $w$ głoszone przezeń kazania, rekolekcje, konferencje, odczyty i wykłady. Z całą pewnością siła oddziaływania mówcy na słuchaczkę była nieprzeciętna, skoro nawet po kilku dziesięcioleciach umiała ona odtworzyć zasadnicze przesłania wyniesione $\mathrm{z}$ owych spotkań. Utrwaliła je na piśmie $\mathrm{z}$ myślą nie tylko ocalenia ich od zapomnienia, ale chyba przede wszystkim z naturalnej potrzeby przybliżenia czytelnikom postaci człowieka o bogatej osobowości, jak również trwałym wpływie na wiele dziedzin polskiego życia narodowego, państwowego, kościelnego czy wreszcie jednostkowego. Tak zrodziły się prezentowane tu teksty.

Do naszych czasów przetrwało pięć opracowań, akcentujących różne aspekty życia i działalności abp. Józefa Teodorowicza. W niniejszej edycji zdecydowano się zaprezentować je w formie pentaptyku, choć każdy z nich stanowi odrębną jednostkę bowiem pomimo niewielkich powtórzeń składają się na swoistą całość. Nie są to rzecz jasna biografie hierarchy, ile raczej próby stworzenia psychologiczno-duchowego portretu, przy wykorzystaniu dostępnego autorce materiału obserwacyjnego i faktograficznego. Jakkolwiek w owej mozaice brakuje wielu koniecznych wręcz elementów, to i tak końcowy obraz zasługuje na akceptację. Pisany jest bowiem przez świadka-obserwatora o krytycznym spojrzeniu na przedmiot badań, przy zachowaniu pełnego pietyzmu a nawet uwielbienia właściwego ludziom pozostającym pod urokiem czyjejś osobowości. Ciekawe, że w tym przypadku nie odnosi się wrażenia retuszowania bądź apoteozowania opisywanego człowieka; wręcz przeciwnie: pojawiają się akcenty świadczące o trzeźwym osądzie autorki, znanej $\mathrm{z}$ indywidualizmu w ocenie zjawisk codziennego życia. Dzięki temu udało się jej uniknąć hagiograficznego podejścia do roztaczającego niemały urok osobisty ormiańskiego hierarchy.

$\mathrm{Na}$ kartach wspomnień pojawiają się różnorodne epizody z życia abp. Teodorowicza $\mathrm{i}$ jego wielostronnego zaangażowania w polskim życiu publicznym zarówno przed rokiem 1918, jak i w II Rzeczypospolitej. Jednak największą wagę autorka przykłada do problematyki religijno-kościelnej, co koresponduje zarówno z misją pasterską hierarchy, jak i stanem zakonnym s. Żulińskiej. Fascynuje ją świat jego wewnętrznych przeżyć i doświadczeń ascetycznych, odsłaniany przezeń wprawdzie w pewnej mierze w publikowanych pracach teologicznych, jednak najlepiej widoczny na płaszczyźnie kierownictwa duchowego czy w sporadycznie ogłaszanych drukiem rozmyślaniach i medytacjach o charakterze kontemplacyjnym. Precyzyjnie umiała też oddać sylwetkę charakterologiczną abp. Teodorowicza, podpatrzoną w trakcie wieloletniej bliskiej współpracy.

Dzięki prezentowanym tu materiałom s. Żulińskiej, widzimy abp. Józefa Teodorowicza w wymiarze prawie dotąd nieznanym. Ciekawe, że przyjęta przez autorkę perspektywa bezpośredniego oglądu nie tylko nie dehumanizuje głównego bohatera, ale czyni go jeszcze bardziej wyrazistym, zwłaszcza w wymiarze dojrzałego człowieczeństwa, autentycznego patriotyzmu oraz głębokiego życia religijnego. 
Publikowane niżej źródła pochodzą z Archiwum Zgromadzenia ss. Zmartwychwstanek w Kętach. Posiadają one formę maszynopisu bez miejsca $\mathrm{i}$ datacji powstania. W edycji zachowano język źródła, wzbogacając tekst o niezbędne wyjaśnienia $\mathrm{w}$ formie przypisów. Za udostępnienie materiałów oraz wspaniałomyślną pomoc dziękuję kustoszowi wspomnianej instytucji s. Tarsylli Krymowskiej CR.

\section{S. Barbara Żulińska CR}

\section{Wspomnienia ${ }^{a}$ osobiste o Arcybiskupie Teodorowiczu}

Raz pierwszy zobaczyłam Arcyb[iskupa] Teodorowicza 1902 roku na Święconym u pp. Roszkowskich przy ulicy Dhugosza. Profesor Gustaw Roszkowski ${ }^{5}$ był posłem do Parlamentu Wiedeńskiego i na tej arenie stykał się z Arcypasterzem, którego już dawniej znał z Rady Miejskiej, w której ks. Kanonik Teodorowicz zasiadał jako przedstawiciel ob[rządku] ormiańskiego. Na powitanie jego wszyscy powstali, a on $z$ miłym, pełnym wytworności i godności uśmiechem $\mathrm{z}$ wszystkimi się witał, nie pozwalając przyklękać. Nieraz przy schyłku życia, gdy ktoś starszy chciał przyklęknąć, mówił: „Po co ta gimnastyka?” Zbyt daleko przy stole siedziałam, by słyszeć o czym mówił, została mi w pamięci ta sylwetka wytwornego pana i łaskawego księcia Kościoła.

Następnie widywałam go tylko na ambonie w katedrze ormiańskiej, zwłaszcza w ostatni dzień roku, w którym zawsze robił gruntowny rachunek sumienia z grzechów zaniedbania i zgorszenia. Mówił do elity miasta Lwowa i obarczał ją odpowiedzialnością za moralność sfer niższych. Kilka razy słyszałam go w katedrze łacińskiej z okazji jakichś większych rocznic narodowych. Raz w sali ratuszowej, gdy mówił o modernizmie. Uderzyło mnie wtedy jego wielkie oczytanie i nawoływanie do zapoznania się z prawdziwą mistyką chrześcijańską. Sala była pełna.

\footnotetext{
${ }^{\text {a }}$ Maszynopis w objętości 15 stronic formatu A 4. W prawym górnym rogu nota ołówkiem: „S. Barbara”.

${ }^{5}$ Osoba niezidentyfikowana.
} 
Roku 1908 umarł mój ojciec ${ }^{6}$, który swego czasu nieraz współpracował z arcybiskupem, a przed tym $\mathrm{z}$ kanonikiem Teodorowiczem, w sprawach społecznych, zwłaszcza Arcybractwa Królowej Polski ${ }^{7}$, założonego przez ojca. Nabożeństwo żałobne było w katedrze ormiańskiej, jako że ojciec mój długie lata pracował w szkole PP. Benedyktynek ormiańskich. Nabożeństwo odprawił ks. Ciemniewski ${ }^{8}$, a Arcypasterz siedział na tronie. Poszłam $z$ matką mu podziękować, wyrażał się $\mathrm{z}$ uznaniem o ojcu, uderzył mnie wtedy odcień tkliwości w głosie. „Aha - pomyślałam sobie - a więc ma nie tylko wielki rozum, ale i serce". W papierach ojca znalazłam jeden jego list pisany $z$ Brzeżan ${ }^{9}$, bardzo wyraźnie $z$ prośbą o statut szkoły sług, którą chciał i założył potem w Brzeżanach. List pełen uprzejmości i prostoty, zdradzający serdeczną troskę pasterza o powierzone sobie owce ${ }^{10}$.

Gdy po śmierci ojca zapragnęłam mieć stałego spowiednika, radzono mnie zwrócić się do Arcybiskupa, ale nie śmiałam patrzeć tak wysoko. Nadal tylko słuchałam go na ambonie mówiącego. $Z$ licznych kazań i konferencji wielkopostnych dziś w pamięci uświadamiam sobie następujące, nie umiejąc jednak podać dokładniej ich daty.

${ }^{6}$ Żuliński Józef (1841-1908), absolwent gimnazjum realnego w Warszawie, studiował w Kijowie, Krakowie i Pradze, doktorat uzyskał w 1863 r. na Uniwersytecie Jagiellońskim, zaangażowany w Krakowie w działalność narodową został areszlowany przez władze austriackie, a po zwolnieniu wyjechał do Paryża studiując na Sorbonie. Po powrocie do Galicji, osiadł we Lwowie przyjmując posadę nauczyciela przyrody w Seminarium Nauczycielskim Żeńskim, później uczyl też w kilku innych szkołach: Felicji Wasilewskiej-Boberskiej, ss. Sakramentek, ss. Benedyktynek ormiańskich oraz od 1897 r. pełnił funkcję dyrektora Seminarium Nauczycielskiego Zofii Strzałkowskiej. W 1905 r. przeszedł na emeryturę. Należał do Towarzystwa Pedagogicznego we Lwowie, Towarzystwa Nauczycieli Szkól Wyższych tamże, erygował Arcybractwo Królowej Polski o charakterze filantropijno-opiekuńczym, powołał do życia dom opieki dla służących, schronisko dla starców i szkołę niedzielną dla sług, zorganizował leczniczą kolonię dla dzieci w Rymanowie na Podkarpaciu. Niestrudzony wychowawca młodzieży, żarliwy patriota, zaangażowany w życic Kościoła katolik. AZK, B. Żulińska, Wspomnienia lwowskie, s. 43-60; taż, Dr Józef Żuliński budowniczy Boży. Szkic biograficzny skreślony na podstawie osobistych wspomnien i dokumentów rodzinnych, Katowice 1938.

${ }^{7}$ Arcybractwo Królowej Polski erygowane zostało w 1890 r. we Lwowie z inicjatywy dr. Józefa Żulińskiego. Strukturalnie posiadało cztery wydziały: św. Salomei - opieka nad wdowami, św. Kazimierza opieka nad bezdomnymi chłopcami, św. Stanisława Kostki - opieka nad terminatorami, św. Jadwigi - opieka nad stużącymi. S. Szydelski, Arcybractwo Królowej Korony Polskiej we Lwowie, "Gazeta Kościelna” 23(1916), nr 43, s. 505-506; nr 49, s. 516-520.

${ }^{8}$ Ciemniewski Jan (1866-1947), święcenia kapłańskie w 1893 r., dr teologii i filozofii, 1893-1896 wykładowca filozofii w Polskim Seminarium Duchownym w Detroit (USA), 1896-1997 katecheta w Stanislawowie, 1897-1902 katecheta Seminarium Nauczycielskiego Męskiego w Tamopolu, 1902-1939 katecheta gimnazjalny we Lwowie, 1907-1913 współzałożyciel i wiceprezes oraz prezes (1913-1922) Związku Księży Abstynentów w Małopolsce, 1922-1939 prezes Koła Księży Abstynentów Archidiecezji Lwowskiej, w 1927 r. erygowal Lwowskie Koło Ligi Przeciwalkoholowej obejmując w nim prezesurę, 1914-1939 członek ruchu odrodzeniowego „Eleusis”, od 1933 r. wydawca periodyku „Okólnik Filarecki”, 1939-1945 duszpasterz we Lwowie, wychowawca młodzieży, autor prac $z$ zakresu pedagogiki, katechetyki. W ramach ekspatriacji wyjechał w 1945 r. ze Lwowa, osiadając w Krakowie jako kapelan ss. Karmelitanek. Zmarł 4 VIII 1947 r. w Krakowie. Schematismus archidioecesis Leopoliensis ritus latini 1893-1939, Leopoli 1893-1939, passim; Schematismus [...] 1943, Leopoli 1943, s. 55; Schematyzm archidiecezji w Lubaczowie 1981 r., Lubaczów 1981, s. 134; L. Grzebien, Ciemniewski Jan, [w:] SPTK, t. 1, red. L. Grzebień, Warszawa 1983, s. 225-227.

${ }^{9}$ Brzeżany - miasto powiatowe, woj. Tarnopol.

${ }^{10}$ Ks. Józef Teodorowicz pełnił w latach 1890-1897 funkcję proboszcza parafii ormiańskokatolickiej w Brzeżanach. 
Przepięknie mówił w rocznicę Skargowską w katedrze łacińskiej ${ }^{11}$. Zaczął od słów: „Wstań, weźmij łoże twoje i chodź!” Wykazał, że nie obchodzono rocznicy ani w setną, ani w dwusetną jego ${ }^{\mathrm{b}}\left[{ }[. .]^{\mathrm{b}}\right.$ ale dopiero dziś, gdy naród zaczął się kajać, wchodzić w siebie i odradzać się, coraz lepiej rozumiejąc jego słowa apostoła, kaznodziei, doktora polskiego Kościoła, słowo sędziego swego narodu, słowo proroka, którego prawdziwości złożyła smutne świadectwo historia. „Wszystkie jego nauki - mówił Arcypasterz - dadzą się zamknąć w jednym ideale: miłość Ojczyzny”. On pierwszy do ojczyzny zawołał: „O matko moja”, a ponad to wołanie już wyżej ojczyzny nie mógł podnieść. II ideał Skargi to równość wszystkich stanów, III to mądrość narodowa. I kazał w świetle tych ideałów siebie osądzić. Po tym obrachunku wykazał, że sprężyną działalności Skargi i źródłem jego natchnienia była miłość Boga i tu mówca wszedł na swój ulubiony temat: ,żenienia” miłości Ojczyzny z milością Chrystusa. Zakończył, dając sylwetkę Skargi matejkowską, który wyrzuca ognie $z$ swej duszy i przelewa je w serca współbraci. „Ale - mówił - wypadałoby dać dwie inne sylwetki, dwa inne typy: jeden - co okiem wieszczym sięga w przyszłość i przepowiada nie tylko upadek narodu ale i jego odrodzenie, drugi - co się wsłuchuje w głos Boży wołając: «Mów Panie, bo sługa Twój słucha»". „- O, Panie - końezył - niech się Ojczyzna nasza odrodzi, niech dłoń Twa włoży narodowi wieniec zamiast popiołów, zamiast żałoby płaszcz szkarłatny. Niechaj głos Skargi wyjedna dzień ubłagania Twego, niechaj kości Skargi, które były zakładem kary i pokuty staną się zakładem naszego zmartwychwstania".

Wrażenie było potężne, długie lata mówiono o tym kazaniu, poruszyłó ono do działania i młodzież, i nauczycielstwo. Pod jego wpływem skreśliłam obrazek sceniczny: „Duch Skargi”, który był odgrywany w roku jubileuszowym po szkołach.

Drugie, jeszcze potężniejsze kazanie wygłosił 1913 roku w 50. rocznicę powstania, które wyszło w zbiorze: „Na przełomie" ${ }^{\text {.12 }}$. Gdy na Jasnej Górze dokonano zbrodni ${ }^{13}$, urządzono w katedrze nabożeństwo ekspiacyjne. Arcybiskup wtedy mówił o perfidii wroga, który tak bezcześci nasze świętości itd. Najsilniejsze było zakończenie. „Winien jest wraży rząd, że nasyła swoich ludzi do zakonu, winien nieszczęsny Macoch, ale przede wszystkim wy jesteście winne, Polki-ziemianki, że bronicie waszym synom pójść za głosem powołania, że taką atmosferę w domu wytwarzacie, że się te powołania rozwinąć nie mogą. Więc w kornej ekspiacji

${ }^{12}$ Uroczystość 300. rocznicy śmierci ks. Piotra Skargi SJ miała miejsce w 1912 r. w Bazylice Metropolitalnej ob. łac. 29 IX 1912 r. Mszę św. celebrował metropolita lwowski abp Józef Bilczewski, kazanie wygłosił abp Józef Teodorowicz. Archiwum Zgromadzenia ss. Sercanek w Krakowie (dalej cyt.: AZSK), J. Bilczewski, Dziennik, Lwów 1900-1921, s. 221, mps, bsygn.

b-b Brak teksta. Powinno być: śmierci.

${ }^{12}$ Kazanie nosiło tytuł: Dwie epoki. Mowa ta byla wypowiedziana w r[oku] 1913 w archikatedrze lwowskiej w 50-ta rocznice powstania [18]63 r. J. Teodorow icz, Na przetomie. Przemówienia i kazania narodowe, Poznań 1923, s. 3-24.

${ }^{13}$ Nawiązanie do kradzieży kosztowności z ołtarza Matki Bożej Częstochowskiej oraz zabójstwa stryjecznego brata Wacława Macocha w 1910 r. przez paulina o. Damazego Kacpra Macocha. Został on skazany w 1912 r. przez sąd na 12 lat katorgi i pozbawienia wszelkich praw. 
przyrzeknijcie Najśw[iętszej] Pannie, że i dla was, jak dla naszych babek, dumą będzie wychowanie syna na sługę ołtarza, a gdy będą prawdziwe powołania, to się taka zbrodnia nie powtórzy".

[W roku - J.W.] 1910 przypadała rocznica grunwaldzka, upał lipcowy już w czerwcu ubezwładniał. Ponieważ główna uroczystość miała się odbyć w Krakowie, więc też we Lwowie przesunięto ją na 29 czerwca $^{14}$. Na prześlicznym cmentarzyku koło ormiańskiej katedry ustawiono ołtarz i krzesła i tam odbyło się solenne nabożeństwo, a Arcypasterz miał kazanie. Nie negując waleczności polskiego rycerstwa ani zdolności Witolda ${ }^{15}$, podniósł przede wszystkim ofiarę Jadwigi ${ }^{16}$, która to zwycięstwo przygotowała.

Z innych nauk jego nic sobie dziś przypomnieć nie mogę. [W - J.W.] 1912 roku w rocznicę św. Klary ${ }^{17}$ wygłosił u ss. Franciszkanek (gdzie często zachodził, darząc zakonnice wielką łaskawością) przepiękne kazanie o życiu z Panem Jezusem i dla Niego. Rozwinął tu zasady mistyki chrześcijańskiej, a mówił o miłości Chrystusa w taki sposób, że łzy lałam jak bóbr, widząc całe szczyty tego zjednoczenia. Tę samą naukę powtórzył potem na rekolekcjach dla pań w katedrze ormiańskiej. W czasie tych rekolekcji uderzyła mnie jeszcze inna nauka, a mianowicie o śmierci na łle przypowieści o 10 pannach. A więc śmierć jest wyjściem naprzeciw Oblubieńca.

Od roku 1911 zetknęłam się z Nim bliżej. Mając trudności ze strony spowiednika co do kwestii swego powołania, poszłam się radzić Ekscelencji. Po raz pierwszy znalazłam się w kapliczce maleńkiej w jego pałacu, a w której później tyle łask za jego pośrednictwem miało na mnie spłynąć. Jak zwykle był ostrożny i z rezerwą, zachęcił do częstszej spowiedzi, by się dać poznać. Niestety, poznał mnie i z opowiadań znajomych i zaproponował, bym wstąpiła do ss. Ormianek ${ }^{18}$, które potrzebowały energicznej ręki. Ale odpowiedziałam, że ja chcę siebie zreformować a nie innych. Gdy już jasno widziałam, że tylko w duchu O. Semenenki ${ }^{19}$ znajdę

${ }^{14}$ We Lwowie głównej uroczystości przewodniczył metropolita łaciński abp Józef Bilczewski, celebrując 29 VI 1910 r. Mszę św. polową na stadionie sportowym. AZSK, J. Bilczewski, Dziennik, dz. cyt., s. 68.

${ }^{15}$ Witold Kiejstutowicz (ok. 1350-1430), wielki książę litewski od 1401 r. do śmierci, brat stryjeczny Władysława Jagiełly.

${ }^{16}$ Św. Jadwiga Andegaweńska (1374-1399), od 1384 r. królowa Polski, od 1386 r. żona króla Władysława Jagiełły, stała u źródeł procesu chrystianizacji Litwy, przyczyniła się do erygowania w 1397 r. Wydziału Teologicznego w Akademii Krakowskiej, zasłużona w dziele utrwalania religii katolickiej i umacniania Kościoła w swoim państwie. Beatyfikowana w 1979 r., kanonizowana w 1997 r. K. Kuźmak, Jadwiga Andegaweńska, [w:] Encyklopedia Katolicka (dalej cyt.: EK), t. 7, red. zbior., Lublin 1997, kol. 658-661.

${ }^{17}$ Św. Klara z Asyżu (1193 lub 1194-1253), współzałożycielka Zakonu ss. Klarysek.

${ }^{18}$ We Lwowie funkcjonował klasztor ss. Benedyktynek obrządku ormiańskokatolickiego, do którego z braku powołan wśród kobiet Ormianek zgłaszały się również Polki obrządku rzymskokatolickiego.

${ }^{19}$ Semenenko Piotr (1814-1886), święcenia kapłańskie w 1841 r. w Rzymic, dr teologii, 1840-1845 przełożony generalny Zgromadzenia Księży Zmartwychwstańców, w 1842 r. zlożył śluby zakonne, w $1850 \mathrm{r}$. ułożył nową regułę zakonną, 1873-1886 ponownie przełożony generalny, w 1880 r. erygował dom we Lwowie, w 1884 r. w Krakowie, w 1863 r. zorganizował misję zakonną w Bułgarii, w 1866 r. doszedł do skutku jego plan erygowania Kolegium Polskiego w Rzymie. Był autorem naukowych i popularyzatorskich prac teologicznych oraz filozoficznych. H.E. Wyczawski, Semeneko Piotr Adolf Konstanty, w: SPTK, t. 4, red. H.E. 
szczęście, radził Niepokalanki ${ }^{20} \mathrm{i}$ kazał mi do nich napisać. Napisałam, ale w takim tonie, że musiały mi odmówić, bo wyraźnie napisałam, że mnie rażą dwa chóry. Nie bardzo chciał się zgodzić na nasz zakon ${ }^{21}$ (nie znał go wtedy, a był pod urokiem Jazłowca ${ }^{22}$ ), napisał do swego dawnego spowiednika Arc[ybiskupa] Webera ${ }^{23}$, podówczas już Zmartwychwstańca, by on napisał, czy nasze siostry nie wynaradawiają, mówił nawet o mnie z O. Smolikowskim ${ }^{24}$, który go zapēwnił, że u sióstr jest pietyzm dla ducha O. Piotra ${ }^{25}$. Gdy jednak zwlekałam, powiedział: „Zanadto filozofujesz, uważaj byś nie przefilozofowała powołania, które jest oddaniem się Bogu bez zastrzeżeń". Odesłał mnie do $\mathrm{O}$. Bakanowskiego ${ }^{26}$, jako kierownika Zgromadzenia w tym czasie. I gdy ciotka moja poszła do Arcybiskupa, by mnie odkręcił w głowie, oświadczył, że tego nie może uczynić, bo ja mam powołanie, a uznał to i O. Bakanowski.

W maju 1913 roku przypadał złoty jubileusz tego ojca. Żyjąc w przyjaźni z Arcybiskupem, mając swoją prymicję w Kamieńcu ${ }^{27}$ w kościele ormiańskim przed cudownym obrazem Matki Boskiej, zapragnął mieć sekundycję $e^{28} w$ katedrze

Wyczawski, Warszawa 1983, s. 38-45.

${ }^{20}$ Zgromadzenie ss. Niepokalanek zastało erygowane w 1857 r. w Rzymie przez Józefę Karską i Marcelinę Darowską, po czym w 1863 r. druga $z$ wymienionych przeniosła je na ziemie polskie. Pierwszym klasztorem był dom w Jazłowcu - archidiecezja lwowska. Celem Zgromadzenia miało być wychowanie religijno-patriotyczne i społeczne oraz kształcenie dziewcząt.

${ }^{21}$ Mowa o Zgromadzeniu ss. Zmartwychwstanek, powołanym do życia przez Celinę i Jadwigę Borzęckie w 1891 r. w Rzymie. Naczelny charyzmat: praca nad odrodzeniem moralnym polskiego narodu.

22 Jazłowiec - miasteczko w pow. Buczacz, woj. Tarnopol.

23 Weber Józef (1856-1918), święcenia kapłańskie w 1873 r. we Lwowie, dr teologii, 1875-1895 kanclerz Konsystorza Metropolitalnego we Lwowie, 1895-1906 biskup pomocniczy archidiec. lwowskiej ob. lac. oraz rektor Seminarium Duchownego we Lwowie, w 1901 r. mianowany arcybiskupem tytularnym. Po rezygnacji z sufraganii w 1906 r. udał się do Rzymu, wstępując t.r. do Zgromadzenia Księży Zmartwychwstańców, 1909-1914 mistrz nowicjatu i 1910-1914 delegat generała w Kanadzie, 1914-1918 delegat generała i superior Kolegium św. Stanisława Kostki w Chicago (USA). J. Wołczański, Listy biskupa Leona Walęgi do arcybiskupa Józefa Bilczewskiego z lat 1900-1922, „Nasza Przeszłość”, 1998, t. 90, s. 203.

${ }^{24}$ Smolikowski Paweł (1849-1926), święcenia kapłańskie w 1873 r. w obrządku wschodnim w Rzymie, śluby zakonne w Zgromadzenia Księży Zmartwychwstańców złożył w 1868 r., dr teologii, 1874-1882 wychowawca $w$ internacie i gimnazjum zakonnym w Adrianopolu, 1882-1892 rektor Zakładu Wychowawczego we Lwowie, 1892-1895 rektor Papieskiego Kolegium Polskiego w Rzymie, 1895-1905 generał Zgromadzenia, 1914-1918 przebywał w klasztorze ss. Zmartwychwstanek w Kętach, 1920-1922 mistrz nowicjatu w Radziwiłlowie, 1922-1926 pracował w Krakowie. B. Micewski, Smolikowski Pawel, [w:] SPTK, t. 7, s. $115-125$.

${ }_{25}^{25}$ Nawiązanie do o. Piotra Semenenki CR.

${ }^{26}$ Bakanowski Adolf Sykstus (1840-1916), święcenia kapłańskie w 1863 r. w Żytomierzu, w 1864 r. wstąpił do Zgromadzenia Księży Zmartwychwstańców w Rzymie, rok później złożył śluby, 1866-1873 pracował w USA jako przełożony polskiej misji w Teksasie, proboszcz par. Trójcy Świętej w Chicago, 1873-1878 pracował w Paryżu, 1878-1881 rektor Polskiej Misji Katolickiej w Londynie, 1881-1888 katecheta we Lwowie, od 1897 r. przełożony prowincji galicyjskiej, przełożony klasztorów w Krakowie, Wiedniu i Lwowie, autor kazań i rekolekcji. B. Mic ewski, Bakanowski Adolf Sykstus, [w:] EK, t. l, red. F. Gryglewicz, R. Łukaszyk, Z. Sułowski, Lublin 1985, kol. 1268.

${ }^{27}$ Wlaściwie: Kamieńcu Podolskim.

${ }^{28}$ Przestarzałe: jubileusz 50-lecia kapłaństwa. 
ormiańskiej. Arcypasterz siedział na tronie i pięknie przemówił, co streszczone jest w kronice Kęckiej ${ }^{29}$.

Gdy poszłam się żegnać, pokazał mnie stosy skryptów i rzekł: „To życie Pana Jezusa, pracuję nad nim od 25 lat", a było to [roku - J.W.] 1913. Prosiłam o błogosławieństwo - udzielił, prosiłam o spowiedź - naznaczył porę, ale zapomniał, bo wyczekawszy się godzinę w kaplicy, musiałam iść do szkoły. To się często zdarzato $u$ dostojnego Gospodarza. W Nowicjacie otrzymałam jeden list.

W roku 1917 byłam w Warszawie jako młoda profeska w zakładzie św. Anny (chodziłyśmy bez habitów). Arcybiskup przyjechał na obrady episkopatu, zamieszkał w seminarium. Poszłam z s. Michaelą ${ }^{30}$ prosić go ze Mszą św. do nas. Przyjął, ale oświadczył, że nie ma głowy do konferencji. O spowiedź nie wolno mnie było prosić. Rano dnia tego bardzo się modliłam, by Duch święty natchnął go i nam zgłodniałym Słowa Bożego coś powiedział. Istotnie, po Mszy świętej odwraca się od ołtarza i przepięknie rozwinął Ewangelię $z$ wielkiego poniedziałku o Marii namaszczającej Jezusa. Wykazał, że zakonnice często jak uczniowie mówią: „Po co ta utrata czasu na adorację, skoro tyle biednych i potrzebujących czeka na pomoc naszą i pracę". I rozwinął przepięknie o obowiązku adoracji i cząstce Marii w życiu zakonnicy, nawoływał, by nie dać się uwieść pokusie zaniedbywania tej cząstki pod pozorem miłości bliźniego. Przy śniadaniu śmiał się i mówił: „Taki miałem niepokój gdy tu jechałem, pewnieście coś poszachrowały z Duchem świętym". Wypytywał o pracę, warunki itd. i tak bacznie obserwował, że gdy w dwa miesiące potem był w Kętach ${ }^{31}$ u O. Smolikowskiego doradził, by mnie $z$ tej niezdrowej dla młodej zakonnicy atmosfery wycofano. Sam też zajął się w Radzie Szkolnej by mnie reaktywowano, co też nastąpiło w 1917 roku w lecie.

W czerwcu byłam u niego z Matką Małgorzatą ${ }^{32}$ u spowiedzi i odtąd już został mym kierownikiem. „Ufaj Jezusowi, On będzie Twoją siłą, tak w pracy wewnętrznej, jak w obowiązkach zewnętrznych, Ufaj Mu.” Był nad wyraz ojcowski i przystępny.

$\mathrm{Na}$ jesieni, gdyśmy się już zagospodarowały w wynajętych pokojach, przyszedł $\mathbf{z}$ kanonikiem Łukasiewiczem ${ }^{33}$ i przyniósł plik swych medytacji. Rozmawiał

${ }^{29}$ Mowa o kronice klasztoru ss. Zmartwychwstanek w Kętach.

${ }^{30}$ Strawińska Michaela (1873-1945), przed wstąpieniem do Zgromadzenia ss. Zmartwychwstanek kształciła się w konserwatorium we Lwowie, od $1901 \mathrm{r}$. w tymże Zgromadzeniu, zajmowała się nauczaniem j. francuskiego i muzyki w szkołach zakonnych, pełniła obowiązki przełożonej klasztorów w Kętach i Rzymie, od 1926 r. ekonomka generalna w Rzymie. Zmarła w 1945 r. tamże. AAK, Relacja pisemna s. Tarsylli Krymowskiej CR, Kęty 25 IX 2998 r., bsygn.

${ }^{31}$ Kęty - miasto na terenie diec. krakowskiej, w którym mieścił się klasztor ss. Zmartwychwstanek.

${ }^{32}$ Dąbrowska Małgorzata (1880-1949), do Zgromadzenia ss. Zmartwychwstanek wstapiła w 1901 r., mistrzyni alumnatu, przełożona domu we Lwowie, rada i ekonomka generalna, 1926-1938 przełożona generalna, 1938-1946 przelożona prowincji warszawskiej. Zmarła w 1949 r. w Kętach. AAK, Relacja pisemna s. Tarsylli Krymowskiej CR, Kęty 25 IX 2998 r., bsygn.

${ }^{33}$ Lukasiewicz Andrzej (1879-1951), święcenia kapłańskie w 1904 r. we Lwowie w obrządku ormiańskokatolickim, od 1904 r. wikariusz katedralny we Lwowie i katecheta w szkole ss. Benedyktynek ormiańskich tamże, 1905-1909 dyrektor Zakładu Naukowego im. Torosiewicza tamże, 1909-1916 administrator 
łaskawie i wtedy wspomniał pierwszy raz o $\mathrm{s}$. Amacie $\mathrm{A}^{34}$, która właśnie wtedy opuściła Niepokalanki i miała do Lwowa przyjechać, polecał ją Matce Małgorzacie, jako też proponował, czy byśmy nie objęły zakładu imieniem Wiktorii Niedziałkowskiej ${ }^{35}$, który ona prowadziła. Zakładu przyjąć nie mogłyśmy, bośmy sił odpowiednich nie miały, ale miłą była nam ta życzliwość Ekscelencji. Zaprosił wtedy Matkę, by mu przychodziła czasem sekretarzować, na co Matka Małgorzata z radością przystała. Niedługo potem polecił jej rekolekcje z panią Kozicką ${ }^{36}$, sodaliską i prowadzenie sekcji eucharystycznej $w$ tejże Kongregacji. Pierwsze posiedzenie odbyło się w domu Podlewskiej przy ul. Kraszewskiego 2/2. Był na nim Ekscelencja, przemawiał i między innymi rzekł: „Nie wolno nam do Pana Jezusa stosować metody krawca, który najbardziej oszczędza krając materiał. I Pan Jezus jest hojny i wszystkiego możemy się po nim spodziewać i my mamy być dla Niego hojne i ufać Mu, że On i najmniejszym co dać możemy się uraduje" (rok 1918).

Rok 1917-[191]8 był rokiem, gdy prawie co niedzieli miewał kazania (chyba, że wyjeżdżał do Wiednia, Warszawy, czy Krakowa). Tam jeździł najczęściej, jako że z Ks. Metropolitą Sapiehą ${ }^{37}$ wiązała go przyjaźń i bez niego nic nie przedsięwziął, gdy chodziło o większą akcję. U Zmartwychwstańców, gdzie zwykle stawał, zostawił pamięć przyjaciela bardzo łatwego w pożyciu i wielkiego dystrakta ${ }^{38}$. Zabierał każdy ołówek i raz na dworcu wyjął ich cały plik i oddał odprowadzającemu

par. ormiańskokatolickiej w Czerniowcach (Bukowina), 1916-1921 kanonik gremialny Kapituły Katedrainej we Lwowie, 1921-1944 proboszcz par. Czerniowce, działacz społeczno-patriotyczny tamże, od 1932 r. prezes Związku Stowarzyszeń Polskich w Rumunii, po zajęciu Bukowiny w 1940 r. przez Sowietów wyjechał do Craiowej (Wołoszczyzna) skąd w 1941 r. powrócił do Czerniowiec, w 1944 r. więziony w Bukareszcie a po wyjściu na wolność katecheta w polskim gimnazjum tamże, potem wyjechał do Craiowej skąd w 1947 r. udał się do Krakowa, był duszpasterzem przy kościele św. Idziego. Odznaczony orderem Polonia Restituta. Zmarł 26 I 1951 r. w Krakowie. T. Zaleski, Slownik biograficzny duchownych ormianskokatolickich oraz duchownych rzymskokatolickich pochodzenia ormiańskiego w Polsce w latach 1750-2000, Kraków 2001, s. 71-72.

${ }^{34}$ Kossowska Amata (1879-1934), dr filozofii, nauczycielka w Zakładzie Wiktorii Niedziałkowskiej we Lwowie, później kierowniczka placówki, od 1919 r. w Zgromadzeniu ss. Zmartwychwstanek, nauczycielka w Seminarium Nauczycielskim ss. Zmartwychwstanek w Warszawie, kierowała Zakładami Naukowymi (przedszkole, szkoła powszechna, gimnazjum, ćwiczeniówka) prowadzonymi przez ss. Zmartwychwstanki w Warszawie-Żoliborzu oraz pełniła obowiązki przełożonej domu tamże. Zmarła w $1934 \mathrm{r}$. w Warszawie. AAK, Relacja pisemna s. Tarsylli Krymowskiej CR, Kęty 25 IX 2998 r., bsygn.

${ }^{35}$ Niedziałkowska Rawicz Wiktoria (1851-1914), związana ze środowiskiem Warszawy, w $1878 \mathrm{r}$. przeniosła się do Lwowa zakładając pensjonat dla dziewcząt, członkini Czytelni dia Kobiet, Koła Pań TSL, założycielka gimnazjum żeńskiego o profilu klasycznym, w $1901 \mathrm{r}$. założycielka liceum umożliwiającego kobietom ubieganie się o indeks uniwersytecki, w 1908 r. założycielka gimnazjum realnego bez j. greckiego. AZK, B. Żulińska, Moje wspomnienia, passim.

${ }^{36}$ Osoba niezidentyfikowana.

${ }^{37}$ Sapieha Adam Stefan (1867-1951), święcenia kapłańskie w 1893 r. we Lwowie, dr prawa kanonicznego, w 1894-1895 wikariusz par. Jazłowiec, 1895-1897 studia specjalistyczne w Rzymie, 1897-1901 wicerektor Seminarium Duchownego we Lwowie, 1901-1902 bez zatrudnienia, 1902-1911 kanonik gremialny Kapituły Metropolitalnej we Lwowie, 1906-1911 sekretarz osobisty Piusa X, 1911-1925 biskup krakowski, 1925-1951 metropolita arcybiskup krakowski, w 1946 r. mianowany kardynałem. J. Wołczański, Adam Stefan Sapieha w korespondencji z biskupami Galicji (Malopolski) w latach 1900-1939, [w:] Kardynat Adam Stefan Sapieha. Środowisko rodzinne, Życie i dzieło, red. S. Stępień, Przemyśl 1995, s. 93-141; Księga Sapieżynska, t. 1-2, red. J. Wolny, Kraków 1982-1986, passim.

${ }^{38}$ Przestarzałe: człowieka roztargnionego. 
go ojcu. Zawsze czegoś zapomniał: to zegarek, to pieniądze zostawały w pokoju itp. Raz już dorożka czeka, a godzina odjazdu się zbliża, a Pasterza nie ma. Cały dom w ruchu, bo gdzież się podziały sztuczne zęby. Patrzą do zlewu, śmieci, do szuflad itd. Wreszcie Arcybiskup zamierza jechać bez nich, sięga do kieszeni po rękawiczki i tam je znajduje ku wielkiej uciesze wszystkich.

Gdy był raz w Kętach z Ks. Metropolitą u O. Smolikowskiego, u którego się często spowiadał, rano bawili się dostojni goście rzucaniem jaśków.

We Lwowie często widywałam go, jak z swoim bratem p[anem] Michałem ${ }^{39}$ chodzili na Wysoki Zamek ${ }^{40}$. W czasie nieobecności Matki Małgorzaty we Lwowie nieraz sekretarzowałam Ekscelencji. Przyznam się, że to zajęcie, jakkolwiek zaszczytne, uważałam za stratę czasu, bo Arcypasterz rzecz, którą ja z trudem, nieraz w nocy przepisywałam, od nowa zmieniał i dyktował inaczej. Wtedy chodził po pokoju i bawił się biskupim krzyżem, albo podrzucał cwikier, który mu raz po raz upadał albo balonikiem podrzucał. Te ruchy z psychologicznego punktu były wythumaczone, spotyka się zawsze u wielkich myślicieli. Trzeba było pisać bardzo prędko, a nie pytać, by nie przerywać myśli autorowi. Czasem, gdy użył ironii lub dowcipu, patrzył, jakie to wrażenie robi i pytał, a że ja zawsze z prostotą opowiadałam, że nienawidzę polityki i żal mi, że ona tyle czasu zajmuje Pasterzowi, nazwał mnie „Oberbischof"4l. Nazwał mnie i dlatego, że z zaufaniem nieraz krytykowałam posunięcia innych pasterzy i księży. Gdy wybuchła w sejmie polskim ta straszna afera ze Śląskiem, gdy Arcybiskupowi zarzucono zdradę stanu i całe społeczeństwo było tym oburzone ${ }^{42}$, razu pewnego powiedziałam, że za to Panu Bogu

${ }^{39}$ Teodorowicz Michal (1868-1924), brat abp. Józefa Teodorowicza, urzędnik bankowy we Lwowie, zmarł 13 III 1924 r. tamże, pochowany na Cmentarzu Lyczakowskim tamże. Archiwum Lvivśkoji Obłasti u Lvovi (dalej cyt.: ALOL), [Księga pogrzebów, pole 52-54], bmr, rps, bsygn.

${ }^{40}$ Wysoki Zamek - wzniesienie w centrum Lwowa $\mathrm{z}$ resztkami fortyfikacji.

${ }^{41}$ Niem.: dosłownie - biskup-starszy, szef.

${ }^{42}$ Nawiązanie do zaangażowania się abp. J. Teodorowicza i bp. Adama Stefana Sapiehy w akcję plebiscytową na Śląsku 1920-1921, kiedy to usiłowali zbojkotować dekret wrocławskiego kard. Adolfa Bertrama z 21 XI 1920 r., zakazujący duchowieństwu pod karą suspensy uczestniczenia w tejże akcji bez zgody miejscowego proboszcza oraz zabraniający wszelkiej działalności kapłanom spoza diecezji wrocławskiej. Dążyli nadto do storpedowania działalności Wysokich Komisarzy Kościelnych wysłanych przez Rzym na Śląsk, nicprzychylnie nastawionych do polskiej racji stanu. Rozporządzenie faworyzowało stronę niemiecką, bowiem na Górnym Śląsku $75 \%$ proboszczów miało pochodzenie niemieckie. Interwencje obu polskich hierarchów w Rzymie oraz ich korespondencja ze Stolicą Apostolską doprowadzity do eskalacji obustronnych napięć. Przysłowiowej oliwy do ognia dolał abp Teodorowicz, ujawniając publicznie fragment raportu do MSZ w Warszawie posła polskiego przy Watykanie Józefa Wierusz-Kowalskiego z niepochlebną oceną sekretarza stanu kard. Pietro Gasparriego. Doszło do skandalu dyplomatycznego, którego widownią stał się nie tylko Sekretariat Stanu Stolicy Apostolskiej, ale również polski parlament. Na forum sejmu, grupa posłów z Janem Brylem na czele (PSL „, Piast”) oskarżyła abp. Teodorowicza o zdradę stanu oraz popsucie relacji Stolica Apostolska-Rzeczypospolita Polska. Debaty w komisjach sejmowych na ten temat trwały od 18 V do 6 VII 1921 r. Wielkim obrońcą ormiańskiego hierarchy okazal się jego przyjaciel bp Adam Stefan Sapieha. Wprawdzie obaj duchowni nadwyrężyli nieco swój autorytet w społeczeństwie, ale niemałym sukcesem całej sprawy był niewątpliwie fakt uświadomienia Stolicy Apostolskiej szkodliwości zakazu udziału duchownych w akcji plebiscytowej. Dzięki ich postawie europejska opinia publiczna mogła zapoznać się z argumentami na rzecz słuszności polskiej racji stanu w odniesieniu do Śląska. S. Wilk, Episkopat Kościola katolickiego w Polsce w latach 1918-1939, Warszawa 1992, s. 341-349. 
dziękuję, bo go to odwróci od polityki a pozwoli mu się bez reszty zająć tylko mistyką. „A dlaczego tego siostra chce?” - spytał. „Bo chcę Ekscelencję widzieć na ołtarzu” - rzekłam. A on: „Moja siostro, proszę się modlić, bym mógł się znaleźć pod ołtarzem".

Gdy w sejmie była dyskusja o reformie rolnej, Arcybiskup był przeciwnikiem gwałtownego rozwiązania tej sprawy i napisał artykuł przeciw swym przeciwnikom, bardzo zjadliwy. Pamiętam, że porównał jednego $\mathrm{z}$ nich do Rocha Kowalskiego $\mathrm{z}$ „Potopu”43 itp. Gdy skończył mi dyktować tę replikę, spytał: „No i co siostra na to?" A ja rzekłam z całym zuchwalstwem: „To nie pasuje arcybiskupowi, choć jest bardzo dowcipne". Na drugi dzień każe mi pisać nową, zupełnie inną, poważną i rzekł: „Cóż, zadowolona siostra?” Uklękłam i przeprosiłam za zuchwalstwo, a on pobłogosławił. I takich epizodów było wiele, ale niestety nie pamiętam, a byłam zbyt zapracowana, by je spisywać.

W kazaniach $\mathrm{z}$ tej epoki zawsze poruszał sprawę wojny i nadzieję odrodzenia. Pokój Brzeski $1918^{44}$ roku zdawał się ją przekreślać, wtedy wygłosił w święto Królowej Polski w katedrze łacińskiej słynne kazanie o ufaniu przeciw nadziei (w zbiorze „Na przełomie" ${ }^{45}$ ).

Po słynnej mowie w Izbie Panów w Wiedniu, całe społeczeństwo składało mu hołd $^{46}$. Poszłyśmy $z$ delegacjami towarzystw kobiecych, mile nas przyjął i z całą

${ }^{43}$ Dzieło literackie Henryka Sienkiewicza.

${ }^{44}$ Dnia 9 II 1918 r. państwa centralne zawarły pokój w Brześciu Litewskim z przywódcami Ukraińskiej Republiki Ludowej. Oddawał on m.in. Chełmszczyznę Ukrainie, a kwestię polską uznano za problem wewnątrzniemiecki. Na znak protestu Rada Regencyjna ogłosiła orędzie, określając ów akt nowym rozbiorem Polski.

${ }^{45}$ Wystąpienie nosilo tytul: Ufanie przeciw nadziei. Kazanie wygloszone w bazylice lwowskiej w uroczystość Królowej Korony Polskiej w 1918 r. wkrótce po układzie brzeskim. J. Teodorowicz, Na przelomie, s. $147-161$.

${ }^{46}$ Nawiązanie do dwukrotnego wystąpienia abp. Teodorowicza na forum wiedeńskiej Izby Panów 30 VI i 30 X 1917 r., w których domagał się reaktywowania państwa polskiego. Komentując nieco póżniej owo październikowe wystąpienie, hierarcha pisał: , „...] nie przemawiałem jako poddany Austrii, ale jako rzecznik narodu, nie zamknąłem się w ramach bieżących spraw, ale rozbierałem je w związku z całą przeszłością, nie apelowałem do racji samych politycznych, ale odnosiłem się do duszy wprost i sumienia, nie prosiłem, ale stawiałem pod sąd zaborców, sąd moralny i Boży - właśnie dlatego, jak myślę, czuła się Izba Panów i zaskoczoną, i jakby przytłoczoną, i milczała. [...] Nie odnoszę w niczym do siebie wrażenia tego przemówienia w kraju, ale jedynie odnoszę je do idei, której $z$ woli Bożej byłem rzecznikiem i wyrazicielem. Bóg mnie wziął za narzędzie słabe, ażeby w przeprowadzanej rozprawie między ciemiężcami Polski a Polską był w dziejach ślad tej drogi Opatrznej, na której stanął traktat wersalski. Nie chciałbym też mówiąc to choćby pozorami samymi budzić przypuszczenie, że lepiej widząc od tych zacnych i zasłużonych ludzi górujących nade mną swym doświadczeniem politycznym i owocami politycznej pracy, sobie jakąkolwiek w tym przypisuję zasługę. Różnica między nami ta była, że oni wyłącznie myśleli kategoriami politycznymi, ja zaś w koncepcjach politycznych miałem i inny czynnik - to jest moralny i mistyczny. Czyż w ogóle mogło być inaczej? [...] I winienem to powiedzieć dzisiaj, że jeśli miałem i o ile miałem jedną myśl przewodnią o przyszłych losach narodu i Ojczyzny, to nie zawdzięczałem jej jakimś bystrym politycznym koncepcjom albo darowi kombinacji czy przewidywania. Nie. Miałem ją dlatego, że patrzyłem w ogólnym wirze i chaosie wojny w igłę magnesową Opatrzności, wskazującą w jedną zawsze stronę. Ile to razy przychodziły w czasie tej wojny chwile bardzo ciężkie, które się zdawały w niwecz obracać wszystkie nadzieje narodu. lle razy zamiast promieni światła, tylko tym bardziej się kłębiły gęste chmury. Ile to razy zawód, zdrada i złość zdawały się 
pokorą powiedział: „Pewien takt moralny nie pozwala mi odnieść tej manifestacji do mojej osoby, przyjmuję ją jako wyraz waszej miłości dla wspólnej sprawy, chcecie mnie powiedzieć, że się ze mną łączycie. Jednoczy nas myśl, że powstanie Polski przewidziane przez wieszczów jest dla nas pewnością realną, utkana ona $z$ nadziei i realnego rachunku. Niech ona was, moje panie, zagrzewa do czynu i przenika wszystkie arterie życia społecznego". (Ogólny sens przemówienia nie dosłowny - ale spamiętany).

W roku 1918 na jesieni zostałyśmy bez mieszkania, ponieważ wymówiono pracę siostrom w kuchni wojennej związanej z mieszkaniem. Całomiesięczne poszukiwanie nie dało pozytywnych wyników i wtedy przyszedł z pomocą Arcypasterz, oddając nam dwie sale w nieczynnej podówczas bursie Torosiewicza ${ }^{47}$ przy ul. Skarbkowskiej. Wdzięczne za dobroć, zamieszkałyśmy tam z końcem października, a 1 listopada Rusini zajęli Lwów ${ }^{48}$. Na szczęście nie było Arcybiskupa ${ }^{49}$, bo mogła go spotkać krzywda mimo, że swego czasu łączyła go przyjaźń osobista z Metropolitą Szeptyckim ${ }^{50}$. Przyjechał po oswobodzeniu Lwowa z końcem listopada $\mathrm{z}$ wolnej już Warszawy i wygłosił podniosłe kazanie w kościele św. Marii Magdaleny na nabożeństwie za poległych obrońców. Drukowane kazanie o obronie Lwowa powiedziałw swej katedrze $\mathrm{e}^{51}$, gdy już wróg był odparty.

Dnia 26 grudnia [1918 r. - J.W.] wpadł ruski szrapnel do jego pracowni i zniszczył część rękopisu i meble. Arcybiskup był w Warszawie, gdzie już zajmo-

sprzysięgać na Polskę. Wtedy to zwykłem patrzeć ponad ten wir i tan straszliwych namiętności w igłę magnesową Opatrzności, obracałem me oczy ku eucharystycznej Hostii, gdy ją podnosiłem na ręku lub wznosilem w monstrancji i mówiłem: «Nie głośni i potężni wodzowie świata, ale Ty, Panie, ukryty i cichy dzierżysz losy tej wojny w swym ręku. Nic w bystrych kombinacjach polityków, ale w Twoim przejrzeniu jest jej rozprawa i zwycięstwo, a Tyś, o Panie, sprawiedliwy»". Archiwum Kurii Metropolitalnej w Krakowie (dalej cyt.: AKMK), J. Teodorowicz, Mowa w Izbie Panów, bmr, mps, sygn. TS IX/94.

${ }^{47}$ Słynny Zakład Wychowawczy dla Sierot Obrządku Ormiańskiego we Lwowie fundacji Józefa Torosiewicza (1784-1869), erygowany w 1865 r. Na mocy zapisu donacyjnego, zakupiono na ten cel kamienicę od rodziny ormiańskiej Krzysztofa i Katarzyny Barączów przy ul. Skarbkowskiej 21 we Lwowie. Zarząd instytucji spoczywał w ręku Kapituły Katedralnej. W 1882 r. bursa gościła w swych murach blisko 50 wychowanków. T. Zaleski, Biskup ormiański Izaak Mikolaj Isakowicz „Zlotousty”. Duszpasterz, spolecznik i patriota 1824-1901, Kraków 2001, s. 63-64.

${ }^{48}$ Wojna ukraińsko-polska o Lwów i Galicję (Małopolskę) Wschodnią rozpoczęta 1 XI 1918 r., trwała w mieście do 22 listopada t.r., natomiast na prowincji do lipca $1919 \mathrm{r}$.

${ }^{49}$ Abp Józef Teodorowicz przed wybuchem wojny ukraińsko-polskiej wyjechał 30 X 1918 r. do Krakowa na wezwanie bp. Adama Stefana Sapiehy, skąd powrócił do Lwowa po 22 XI 1918 r.

${ }^{50}$ Szeptycki Andrzej (1860-1944), dr praw, dr teologii, po zmianie obrządku tacińskiego na greckokatolicki wstąpił w 1888 r. do nowicjatu OO. Bazylianów w Dobromilu, a potem odbył studia filozoficzno-teologiczne w Kolegium oo. Jezuitów w Krakowie; święcenia kapłańskie w 1892 r. w Przemyślu. W 1896 r. objął funkcję ihumena klasztoru św. Onufrego we Lwowie oraz profesora teologii w bazyliańskim studium w Krystynopolu; 17 IX 1899 r. wyświęcony na biskupa diec. w Stanisławowie, 17 XII 1900 r. przeniesiony na stolicę metropolitów we Lwowie. Metropolita Andrzej Szeptycki. Studia i materialy, red. A.A. Zięba, Kraków 1994, passim.

${ }_{51}$ Mowa nosiła tytuł: Obrona Lwowa. Kazanie nygloszone w katedrze ormiańskiej we Lwowie w r [oku] 1919 w czasie nabożénstwa dziękczynnego za oswobodzenie miasta od Ukraińców. J. Teodorowicz, Na przełomie, s. 207-217. 
wał się swą kandydaturą do sejmu z Ziemi Podlaskiej ${ }^{52}$. Wysoko sobie cenił zaufanie tego ludu, który tak wielką rolę odegrał $\mathrm{w}$ walce o wiarę.

W pierwszych dniach stycznia [1919 r. - J.W.] byłam w Warszawie, odwiedziłam Arcypasterza; mieszkał w konwikcie OO. Misjonarzy, pytał z troską o swą matkę, o to, czy ma co jeść, o całą sytuację. Zaznaczył, że nie może teraz pojechać, bo sprawy sejmu zbyt go absorbują. Nie należał do entuzjastów Marszałka ${ }^{53}$, nazywał go demonem Polski. Po jednym raucie, na którym $z$ nim się zetknął, powiedział: „Nie mogłem dopatrzeć się w nim duszy”. Byłam też u spowiedzi. Z prostotą $\mathrm{z}$ rozmównicy poprowadził do kaplicy i wyspowiadał. U niego to było tak naturalne, że wszelka żenada $w$ podobnych razach ustępowała. Wszak on był przede wszystkim mistrzem duchownym i gdy trzeba było służyć duszy, natychmiast to czynił.

I dopiero znowu go zobaczyłam, gdy przyjechałam na wiosnę 1919 roku z Matką Małgorzatą na sejm nauczycielski, mieszkał już wtedy przy ul. Miodowej na II piętrze $w$ klasztorze pobazyliańskim $\mathrm{i}$ obsługiwał wraz $\mathrm{z} \mathrm{ks}$. sekretarzem ten kościół. Po Mszy świętej wyspowiadał nas obie, a potem zaprosił na śniadanie, które przygotowała wierna Rózia ${ }^{54}$ nastręczona przez ss. Józefitki z Sewerynowa ${ }^{55}$. Przy śniadaniu pytał o życie w obstrzeliwanym Lwowie, piętnował politykę Marszałka, który nie chciał dać pomocy Generałowi Rozwadowskiemu ${ }^{56}$, nie rozumiejąc kwestii kresów naszych. Wreszcie Matka Małgorzata zrobiła mu gorzką, choć $\mathrm{z}$ wielką pokorą wymówkę, że popiera zwinięcie placówki we Lwowie. S. Regina ${ }^{57}$ - przełożona w Kętach, nie chcąc rozstać się z s. Teresąą ${ }^{58}$ młodą profeską, o którą prosiła s. M[arię] Zubylewicz ${ }^{59}$ na dyrektorkę seminarium, które się dopiero co do-

\footnotetext{
${ }^{52} \mathrm{Abp}$ Teodorowicz piastował mandat poselski do Sejmu Ustawodawczego z okręgu siedleckiego z listy Narodowej Demokracji.

${ }^{53}$ Mowa o Józefie Piłsudskim (1867-1935), legitymującym się od marca 1920 r. stopniem Marszałka Polski.

${ }^{54}$ Osoba niezidentyfikowana.

${ }^{55}$ Sewerynów - miejscowość podwarszawska.

${ }^{36}$ Rozwadowski Tadeusz (1866-1928), w latach 1894-1918 służył w armii austro-węgierskiej, od 1918 r. w Wojsku Polskim, 15 XI 1918 - 19 III 1919 dowódca wojsk w Małopolsce Wschodniej w walce z Ukraińcami, szef Polskiej Misji Wojskowej w Paryżu, 1920-1921 szef Sztabu Generalnego, 1921-1922 inspektor armii, 1922-1926 generalny inspektor kawalerii, 1926-1927 więziony w Warszawie i Wilnie, w 1927 r. przeniesiony w stan spoczynku; generał broni. Zmarł 18 X 1927 r. w Warszawie. G. Mazur, Rozwadowski (Jordan-Rozwadowski) Tadeusz, [w:] Kto byt kim w Drugiej Rzeczypospolitej, red. J. M. Majchrowski, G. Mazur, K. Stepan, Warszawa 1994, s. 139-140.

${ }^{57}$ Gostomska Regina (1863-1958), do Zgromadzenia ss. Zmartwychwstanek wstąpiła w 1901 r., socjuszka nowicjatu, przez 50 lat mistrzyni sióstr nowicjuszek w Kętach i w Grottaferrata k. Rzymu. Zmarła w 1958 r. w Rzymie. AAK, Relacja pisemna s. Tarsylli Krymowskiej CR, Kęty 25 IX 2998 r., bsygn.

${ }^{58}$ Czerska Teresa (1904-1961), do Zgromadzenia ss. Zmartwychwstanek wstąpiła w 1928 r., nauczycielka i kierowniczka internatu w szkole ss. Zmartwychwstanek w Warszawie-Żoliborzu, od 1947 r. mistrzyni nowicjatu w Kętach, potem mistrzyni alumnatu najpierw w Warszawie, a następnie w Grottaferrata k. Rzymu. Zmarła w 1961 r. w Rzymie. AAK, Relacja pisemna s. Tarsylli Krymowskiej CR, Kęty 25 IX 2998 r., bsygn.

${ }^{59}$ Zubylewicz Maria (1870-1945), do Zgromadzenia ss. Zmartwychwstanek wstapiła w 1889 r., przełożona domów w Kętach, Warszawie, Rzymie, delegatka przełożonej generalnej na placówki w USA, asy-
} 
stało w nasze ręce od Ochrony Kobiet, prosiła Arcybiskupa przez O. Smolikowskiego, by wpłynął na Matkę Małgorzatę, by zwinęła Lwów, a s. Barbarę dała do Warszawy. Zabolało to Matkę Małgorzatę gdy dostała list Ekscelencji i teraz wykazała zalety s. Teresy jako jedynie powołanej na takie stanowisko, moje niewyrobienie zakonne, wszak dopiero miałam trzy lata po ślubach i straty, jakie poniesie seminarium ochroniarskie, o które sam Arcybiskup walczył w Radzie Szkolnej. Arcybiskup zrozumiał, a widząc jaką to robiło nam przykrość, starał się dobrocią i niesłychaną delikatnością nam nagrodzić i napisał odpowiedni list do O. Pawła ${ }^{60}$.

Po ustąpieniu Ukraińców i oswobodzeniu Lwowa, Komitet przystąpił do otwarcia bursy Torosiewicza. Groził nam znowu brak mieszkania, wtedy Arcybiskup uprosił Komitet, by nam oddano zarząd gospodarski i małe mieszkanko na parterze. Komitet tak uczynił, a matka przyjęła tę pracę. Arcybiskup nieraz odwiedzał zakład, przede wszystkim wstępował do kaplicy, na której drzwiach widniał napis: „Tu mieszka Najświętszy Król naszego zakładu”. Potem szedł do ustępów, twierdząc, że ducha zakładu najlepiej poznaje się po porządku w tamtych miejscach. Na końcu zawsze wstępowal do nas, co podnosiło w oczach komitetu i dyrektora. Był to jeden z tych gestów, świadczących o przedziwnej jego delikatności.

Matka Małgorzata pomagała mu walnie w pisaniu, nawet na kilka tygodni pojechała do Warszawy, w powrotnej drodze się przeziębiła i chorowała; Arcypasterz tym się zaniepokoił i odwiedził. Na początku roku 1920 Matka Antonina ${ }^{61}$ przeniosla Matkę Małgorzatę na stanowisko przełożonej w Warszawie. Opuszczenie Lwowa kosztowało ją bardzo, trzeba było zerwać tak piękną pracę w Kongregacji62. Jeszcze większą ofiarą było dla sióstr, które nie bardzo miały ochoty zostać pod kierunkiem młodszej od siebie i niedoświadczonej s. Barbary. Ta chyba najwięcej odczuła. [Dnia - J.W.] 2/2 $1920 \mathrm{w}$ rocznicę swej konsekracji [arcybiskup - J.W.] miał Mszę św. w zakładzie, po niej była akademia. W końcu przyszedł do nas i cieszył się, że Matka przyjedzie do Warszawy i będzie mu pomagała, zauważył przy tym łzy w moich oczach, zmienił rozmowę, a potem do M. Małgorzaty rzekł: „Ale s. Barbarę to bardzo kosztuje”, a matka odpowiedziała: „To znak, że najwyższy czas, bym stąd pojechała". Arcybiskup podnosił tego ducha wyrzeczenia Matki, a mnie przy spowiedzi wyjątkowo dużo serca okazał.

stentka przełożonej generalnej. Zmarła w 1945 r. w Rzymie. AAK, Relacja pisemna s. Tarsylli Krymowskiej CR, Kęty 25 IX 2998 r., bsygn.

${ }^{60}$ Mowa o zmartwychwstańcu o. Pawle Smolikowskim.

${ }^{61}$ Sołtan Antonina (1857-1931), do Zgromadzenia ss. Zmartwychwstanek wstapiła w 1899 r., pracowała w Częstochowie, w Warszawie jako m.in. organizatorka Zakładu św. Jadwigi i przełożona internatu pod patronatem Towarzystwa Ochrony Kobiet, 1906-1913 asystentka przełożonej generalnej, 1913-1926 przełożona generalna. Zmarła w 1931 r. w Kętach. AAK, Relacja pisemna s. Tarsylli Krymowskiej CR, Kęty 25 IX 2998 r., bsygn.

${ }^{62}$ Kongregacja Maryjna Ziemianek p.w. NMP Kochawińskiej została erygowana 2 VIII 1902 r. przez abp. Józefa Teodorowicza w Kochawinie, początkowo pod nazwą „Kongregacja Mariańska Pań Wiejskich”. Do końca swego życia hierarcha petnil funkcję duchowego moderatora tej instytucji. M. Czermiński, Kochawina w przeszlości i dobie obecnej. Z okazji koronacji obrazu Matki Boskiej w r. 1912, Kraków 1912, s. 75 . 
$\mathrm{Na}$ wiosnę przyjechała do Lwowa Matka Antonina, urządziłam zebranie pań i zaprosiłam Ekscelencję; przyszedł i ucieszył się widokiem Matki, którą pamiętał z pracy jej w Warszawie 1906 roku. Wtedy wchodząc do zakładu św. Jadwigi, gdzie siostry pracowały w ukryciu rzekł: „Witam Zmartwychwstanki, które przyjechały na podbój Warszawy". Byłyśmy z Matką u Arcypasterza; ona się żaliła, że nie ma czasu na oddanie się modlitwie, że boi się o życie wewnętrzne, a on jej odpowiedział: „Matka jest ekonomem Pana Jezusa, więc On bierze na siebie jej uświęcenie". Zaprosił nas do kaplicy na święcenie diakonatu ks. Bogdanowicza ${ }^{63}$, ale zapomniał o nich i święcenia odbyły się kiedy indziej.

Arcybiskup bardzo bolał nad wyprawą Kijowską ${ }^{64}$, wiedząc do czego doprowadzi. Toteż bardzo cierpiał nad pochodem armii wrogiej. Powierzył naszej opiece swą matkę, a sam pojechał do Warszawy. Matkę na alarm (okazało się fałszywy) wywiózł brat do Tarnowa ${ }^{65}$ do Urszulanek, a myśmy niedługo na rozkaz naszej władzy pojechały do Kęt. Stamtąd w interesie wysłano mnie do Krakowa. Dowiedziawszy się, że ks. Arcybiskup staje u Franciszkanów poszłam, ale widziałam się tylko z ks. Bogdanowiczem, szykującym się do ostatnich święceń. Na ul[icy] spotkałam Matkę jego zbolałą wiadomością, że ks. Arcybiskup dał pełne prawa Ks. Metropolicie ${ }^{66}$ do wyświęcenia ks. Adama, że to dla niej jako Ormianki jest bardzo bolesną i pogłębi przedział, jaki się tworzy między Ormianami a Pasterzem zbyt zajętym polityką w stolicy. Nie chcąc tego konfliktu dla Ekscelencji, napisałam list do Warszawy przedstawiając sytuację. Było to dość zuchwałe, ale Arcypasterz zrozumiał, że dyktowała miłość i odpisał tak: „Dziękuję siostrze za wiadomość o Wandzi B[ogdanowicz ${ }^{67}$. Myślałem, że im to obojętne, kto wyświęci. Jadę i sam tego dokonam". Czy nie podziwiać pokory i tej subtelnej miłości, która nikomu nie chce zrobić przykrości.

$\mathrm{Na}$ jesieni Matka Małgorzata została wybraną Radną Generalną, Arcybiskup był wtedy w Rzymie i nie zachwycił się tym wyborem, tracił bowiem wierną po-

${ }^{63}$ Bogdanowicz Adam (1898-1941), święcenia kapłańskie w 1920 r. w Krakowie w obrządku ormiańskokatolickim, wikariusz katedralny i katecheta szkół średnich we Lwowie, 1928-1935 administrator par. Horodenka, 1932 1941 kanonik gremialny Kapituły Katedralnej tamże, na przełomie 1939/40 r. wstąpił do Związku Walki Zbrojnej - obszar lwowski, aresztowany 2 IV 1940 r. przez NKWD we Lwowie, skazany 19 XI t.r. na śmierć, rozstrzelany 24 II 1941 r. we Lwowie. T. Zaleski, Slownik biograficzny, s. 37-38; J. Wołczański, Kaplani-męczennicy - świadkowie wiary Kościola lwowskiego. Ksiqdz Adam Henryk Bogdanowicz (1898-1941), „Radość Wiary” (Lwów), 7(1999), nг 2, s. 17.

${ }^{64} \mathrm{~W}$ wyniku porozumienia rządu polskiego z Ukraińską Republiką Ludową atamana Semena Petlury, doszło 25 IV $1920 \mathrm{r}$. do ofensywy wojsk polskich na Ukrainie zw. wyprawą kijowską. Wojska polskie $7 \mathrm{~V}$ 1920 r. zajęły Kijów, skąd już 10 maja t.r. zmuszone były do ucieczki wskutek kontrofensywy bolszewickiej. Finałem tych zmagań była bitwa warszawska, tzw. cud nad Wisłą 12-25 VIII 1920 r. zakończona klęską armii bolszewickiej. W. Sienkiewic z, Maly slownik historii Polski, Warszawa 2000, s. 271,

${ }^{65}$ Tarnów - miasto powiatowe, woj. Kraków.

${ }^{66}$ Mowa o biskupie krakowskim Adamie Stefanic Sapieże. Autorka błędnie używa tu określenie: „metropolita" w odniesieniu do roku 1920, bowiem tytuł ten przyshugiwał bp. Sapieże od 1925 r. na mocy konkordatu pomiędzy Stolicą Apostolską a Rzeczypospolitą Polską, kiedy powołano do życia metropolię krakowska.

\footnotetext{
${ }^{67}$ Bogdanowicz Wanda - matka ks. Adama Bogdanowicza.
} 
mocnicę, a nadto widział, ile Matkę kosztuje ta decyzja, chciał nawet w Kongrega$\mathrm{cji}^{68}$ wyrobić dyspensę, jednak Matka go powstrzymała, nie chcąc iść przeciw Woli Bożej. Toteż cieszył się Pasterz niepomiernie, gdy w styczniu Matka z Matką Antoniną przyjechały do Polski.

Po powrocie z zagranicy wygłosił w kasynie mieszczańskim odczyt o swej podróży, nie mówiąc ani słówka o tym, że urabiał opinię Polsce i jednał przyjaciół.

$\mathrm{Z}$ czasu pobytu naszego w bursie, jeszcze jeden szczegół nam się przypomina. Do Lwowa przy końcu wojny zawitał Biskup Bandurski ${ }^{69}$. Arcybiskup Bilczewski $^{70}$ nie chciał o tym wiedzieć, konflikt między nimi sięgał jeszcze czasów przedwojennych $^{71}$. Nie dał mu jurysdykcji. OO. Dominikanie przyjęli go do klasztoru na mieszkanie, a Arcybiskup dał mu pozwolenie spowiadania $w$ katedrze orm[iańskiej] i kaplicy zakładu. Fakt ten nadwerężył serdeczny stosunek z Arcyb[isku]pem Bilczewskim, niemniej Arc[ybiskup] Teodorowicz się nie cofnął, okazując się w tym wielkim chrześcijaninem.

W roku 1919 ukazały się w druku medytacje „Mnie żyć jest Chrystus"72. Matka Małgorzata z pietyzmu wydała nawet urywkowe, nieprzejrzyste szkice, co kry-

\footnotetext{
${ }^{68}$ Nawiązanie do Kongregacji Zakonów w Rzymie, którym podlegają sprawy personalno-organizacyjne zakonów i zgromadzeń zakonnych.

${ }^{69}$ Bandurski Władysław (1865-1932), święcenia kapłańskie w 1887 r. we Lwowie, dr teologii, $1889-$ 1893 wikariusz par. Kamionka Strumiłowa, 1893-1895 wikariusz katedry lwowskiej, 1895-1896 sekretarz bp. Jana Puzyny w Krakowie, 1896-1906 kanclerz Kurii Biskupiej tamże, 1899-1906 kanonik gremialny Kapituły Katedralnej na Wawelu, 1906-1917 biskup pomocniczy archidiec. lwowskiej ob. łac., 1906-1912 rektor Seminarium Duchownego, zmuszony przez laciński episkopat galicyjski do rezygnacji z urzędu w $1917 \mathrm{r}$. osiadł po 1918 r. w Wilnie; 1920-1922 kapelan Sił Zbrojnych Litwy Środkowej w stopniu generała, od 1922 r. pełnił funkcje kapelana oboźnego Federacji Polskich Związków Obrońców Ojczyzny, autor patriotyczno-religijnych utworów literackich. Zmarł 6 III $1932 \mathrm{r}$. w Wilnie, ekshumowany po $1991 \mathrm{r}$. do Warszawy. J. Wołczański, Listy biskupa Leona Walęgi..., s. 195; K. Krasowski, Biskupi katoliccy.., s. 23-25 (liczne błędy); informacje własne autora.

${ }^{70}$ Bilczewski Józef (1860-1923), święcenia kapłańskie w 1884 r. w Krakowie, 1884-1885 wikariusz par. Mogiła, 1885-1886 studia w Wiedniu zakończone doktoratem teologii, 1886-1888 studia specjalistyczne w Rzymie, 1888-1889 wikariusz par. Kęty, 1889-1890 wikariusz par. Wszystkich Świętych przy kościele św. Piotra i Pawła w Krakowie, 1890-1891 katecheta Gimnazjum św. Anny tamże, w 1890 r. uzyskał habilitację na Wydziale Teologicznym Uniwersytetu Jagiellońskiego, 1891-1900 profesor teologii dogmatycznej na Wydziale Teologicznym Uniwersytetu Lwowskiego, w roku akad. 1990/01 rektor uczelni, 1900-1923 arcybiskup metropolita lwowski obrządku łacińskiego, odnowiciel życia religijno-organizacyjnego archidiecezji, propagator kultu Najświętszego Sakramentu, Matki Bożej i świętych, autor dzieł teologicznych i wartościowych listów pasterskich. Zmarł 20 III 1923 r. we Lwowie, beatyfikowany w $2001 \mathrm{r}$. we Lwowie, kanonizowany w 2005 r. w Rzymie. J. Wolczański, Biogram i bibliografia prac drukowanych blogoslawionego Józefa Bilczewskiego za lata 1888-1929, w: Blogoslawiony Józef Bilczewski arcybiskup metropolita lwowski obrzadku lacinskiego. Sesja naukowa na Uniwersytecie Jagiellońskim, Kraków 4-5 czerwiec 2002, red. J. Wołczański, Kraków 2003, s. 17-21; informacje własne autora.

${ }^{71}$ Źródło konfliktu tkwiło w fakcie rzekomego narzucenia abp. Bilczewskiemu przez Stolicę Apostolską w myśl sugestii ówczesnego sekretarza Piusa X ks. Adama Stefana Sapiehy na biskupa pomocniczego archidiec. lwowskiej ks. Władysława Bandurskiego. Do tego doszły rozdżwięki między obu dygnitarzami na the pojmowania polskiej racji stanu w dobie monarchii austro-węgierskiej, swego rodzaju konkurencja w dziedzinie sztuki oratorskiej aż po bliżej niesprecyzowane oskarżenia sufragana o nadużycia natury moralnej. J. Wołczański, Adam Stefan Sapieha w korespondencji z biskupami Galicji, s. 107-110.

${ }^{72}$ J. Teodorowicz, ,, Mnie zyć jest Chrystus”, Poznań 1919.
} 
tyka niechętnie przyjęła. Arcybiskup miał żal do niej, co delikatnie wyraził we wstępie. Dedykując mnie książkę napisał: „Siostrze Barbarze, która najbardziej uwzięła się na te medytacje”. A dla Matki Antoniny: „Wielebnej Matce jako dowód zachłanności jej córek". Napisałam recenzję do jednego z periodyków, posłałam $\mathrm{mu}$ ją do Warszawy, obok zamieszczając wynurzenia własne $\mathrm{z}$ tego, co te medytacje mnie dały. On odpisał (zawsze odpisywał na każdy list): „Dziękuję siostrze za tę recenzję, ale jeszcze więcej za tę osobistą. Właśnie celem wydania medytacji było poruszenie w duszach tego, o czym siostra pisze". Zbierałam wszystkie opinie o tej książeczce i zanosiłam je przy okazji, co mu robiło wiele radości.

Trzeba było jednak wydać tom II. Arcybiskup bał się, że znowu podam do druku takie niedokończone szkice. Zwlekał więc, nie chciał przeglądać przepisanych przez Matkę, a przepisywała przy pomocy lupy i prosząc o światło Ducha Świętego, tak były niewyraźne. Pisał je bowiem dorywczo jako wylewy duszy, bez celu wydawania. Do wydania dopiero skłoniła go nasza Matka. Przyszła moja profesja. Arcybiskup napisał mi długi i piękny list, w którym na końcu dodat: „A w upominku siostrze obiecuję, że już nie będę robił trudności w wydaniu medytacji”. Zaraz więc $\mathrm{z}$ ks. Isakowiczem ${ }^{73}$ zabrałam się do ich wydania. I tak ukazały się "Oknuchy ewangehiczne"74. Na egzemplarzu dla mnie napisał: „Obiecane siostrze przy składaniu Jej ślubów - dzisiaj ofiarowuję - Teodorowicz". Wiedział, że nie zrobi mi większej przyjemności, jak raz po raz dodając nowe medytacje. Nawet kilkakrotnie na życzenie jego robiłam spis scen z Ewangelii, które nie miały medytacji, ale [jak - J.W.] zwykle ten spis zgubił. Miał pewne tematy, które kilkakrotnie omawiał, a innych nie tykał. Późniejsze medytacje już nie miały tej prężności i bezpośredniości (mówię o medytacjach na temat Ewangelii). Widać, że przeszedł w inny stan modlitwy, o którym pisał: „Dusza dochodzi do stanu, gdy się tylko milczy i kocha, kocha i milczy". Zajęty był pisaniem „Życiorysu Pana Jezusa"75 i już te medytacje miały charakter fragmentów dzieła.

Roku 1921 opuściłyśmy gościnne mury bursy i przeniosłyśmy się do klasztoru ss. Franciszkanek. Widywałam się coraz rzadziej [z arcybiskupem - J.W.], a i Ekscelencja zajęty sprawami w stolicy coraz rzadziej przebywał we Lwowie, coraz rzadziej miewał kazania.

\footnotetext{
${ }^{73}$ Isakowicz Leon (1897-1944), święcenia kapłańskie w 1919 r. we Lwowie w obrządku ormiańsko-katolickim, 1919-1920 wikariusz kościoła pw. Wniebowzięcia NMP w Warszawie przy ul. Miodowej w Warszawie, od 1920 r. wikariusz katedry lwowskiej, 1920-1922 asystent przy katedrze historii sztuki kościelnej na Wydziale Teologicznym Uniwersytetu Jana Kazimierza we Lwowie, sekretarz abp. J. Teodorowicza, od 1922 r. katecheta Gimnazjum ss. Urszulanek we Lwowie, od 1925 r. analogiczna funkcja w Gimnazjum ss. Nazaretanek tamże, od 1923 r. notariusz Kurii Arcybiskupiej we Lwowie, 1930-1936 kanonik gremialny Kapituły Katedralnej tamże, 1936-1944 administrator a potem proboszcz par. Stanisławów. Zmarł 4 V 1944 r. tamże. J. Wołczański, Wydzial Teologiczny Uniwersytetu Jana Kazimierza we Lwowie 19181939, Kraków 2002, s. 382.

${ }_{74}$ J. Teodorowicz, Okruchy ewangeliczne, Lwów 1923.

${ }^{75}$ Tenże, Jezus Chrystus, t. 2: Od Betlejem do Nazaretu, Poznań 1932; t. 1: Od Jahwy do Mesjasza, Poznań 1936; t. 3: Herold Chrystusa na tle epoki, Poznań 1937.
} 
W roku 1923 umarł Arcybiskup Bilczewski, 20 marca. W Warszawie wtedy odbywała się sesja Episkopatu, wszyscy dostojnicy $z$ kard. Kakowskim ${ }^{76}$ na czele zjechali do Lwowa. W czasie nabożeństwa żałobnego w katedrze kazanie wygłosił Arcyb[iskup] Teodorowicz; kazanie było bardzo piękne. Tego samego dnia wieczorem zaczął rekolekcyjne nauki w swojej katedrze i wygłosił jedną z najpiękniejszych nauk: „Pan Jezus jako wychowawca”.

W rok potem pochował brata swego zacnego pana Michała, który pracując jako kasjer w polskim banku nabawił się niebezpiecznej infekcji, na którą zgasł. Arcybiskup w czasie całej choroby okazywał wielką delikatność. Cierpiał nad możliwością straty prawdziwego przyjaciela i jeszcze więcej nad cierpieniem staruszki matki. Prosił Matkę Małgorzatę, która w tym czasie była we Lwowie, by uprzedziła p[ana] Michała o możliwości katastrofy. Po pogrzebie przyszedł do nas. Leżałam wtedy od dłuższego czasu chora i Matka Małgorzata uprosiła go o odwiedzenie. Przyszedł poważny, zbolały ale wiele balsamu pokoju potrafił wlać do duszy. Okazał niezwykłą dobroć.

Razu pewnego w czasie Mszy świętej w katedrze nie miał wcale zamiaru przemawiać, modliłyśmy się jednak, by zmienił postanowienie. Istotnie po Ewangelii skierowuje się do mnie wzrokiem i grozi mnie, a za chwilę z tronu biskupiego przemawia $i$ to bardzo podniośle. Ponieważ zawsze na jego życzenie notowałam nauki jego, więc i tę odniosłam nazajutrz, a Arcybiskup rzekł: „I znowu siostra szachowała $\mathrm{z}$ Duchem świętym".

Innym razem w dzień zaduszny mają go ubierać w pontyfikalia, a nie ma paliusza i rękawiczek, klerycy i księża się rozbiegają, a on tymczasem zaczyna naukę, choć dosłownie było 20 osób w kościele.

Raz znowu nie było stuły i znowu szukanie, a on z największą cierpliwością czeka. Widząc to kanonik kończący Mszę przy bocznym ołtarzu ściąga z siebie stułę i podaje Pasterzowi. Objął komizm sytuacji, ale na razie ani drgnął. Mówiono, że ma rysy jak z pieczęci średniowiecznych, tyle było spokoju, majestatu i opanowania w twarzy.

Trzeba było widzieć jego przy ołtarzu, jak zatopiony, jak oderwany, z jaką czcią odprawiał Najśw[iętszą] Ofiarę, zwłaszcza przepięknie wyglądał w chwili błogosławieństwa kielichem i Hostią Najśw[iętszą].

Niezatarte wrażenie zostawiła ceremonia umywania nóg. W obrządku ormiańskim ceremonia ta odbywa się $\mathrm{w}$ Wielki Czwartek popołudniu. 12 ubogich brudasów zasiadło w prezbiterium, jeden nakrył sobie nogę bosą czapką, drugi śliną ją mył itp. Zagryzamy wargi ze śmiechu, który zamarł na ustach, gdy do tej gromadki zbliżył się Dostojny Pasterz, jeszcze wyższy w swojej mitrze i z pokorą

${ }^{76}$ Kakowski Aleksander (1862-1938), święcenia kapłańskie w 1886 r. w Warszawie, urzędnik Konsystorza Biskupiego tamże, wykładowca i rektor Seminarium Duchownego tamże, kanonik gremialny Kapituły Katedralnej, 1910-1013 rektor Akademii Duchownej w Petersburgu, 1913-1938 arcybiskup metropolita warszawski, 1917-1918 członek Rady Regencyjnej, w 1919 r. mianowany kardynałem. P. Nitecki, Biskupi Kościola w Polsce. Stownik biograficzny, Warszawa 1992, s. 97-98. 
i pietyzmem klęka przed nędzarzami, obmywa nogi i całuje owrzodzone i brudne stopy biedaków. Śmiech zamienił się w łzy wzruszenia i uczucie wielkiej maleńkości wobec tego olbrzyma duchowego.

Arcybiskup był dowcipny, czasem nawet z zabarwieniem lekkiej złośliwości. Określenia miał dosadne i realistyczne, a zawsze bardzo trafne. Ks. Kanonik Piotrowicz ${ }^{77}$, człowiek oczytany, zacny, nie odznaczał się pięknym głosem. Arcyb[iskup] powiedział: „Śpiewa jak wół zarzynany”. Była mowa o jednym Zgromadzeniu, że kieruje się zasadą Chrystusa: „Bądźcie prości jak gołębie, roztropni jak wężowie”. A Arcypasterz rzekł: „Tylko, że u nich wąż dawno zjadł gołębia”. Na jedną siostrę skrzywioną stale i chodzącą własnymi ścieżkami powiedział: „To naczynie dziwnego nabożeństwa". Był dosadny w swych określeniach, nie żałował słów bardzo skrajnych wtedy, gdy mówił o kimś w kole zaufanym z poczuciem humoru i dowcipem. Wobec obcych czy wobec większego audytorium był pełen wytworności, dowcip pełen finezji, nigdy nie uranił miłości.

Tę miłość praktykował i w czynie. Razu pewnego musiałam na oznaczoną godzinę mieć 10000 złp dla pewnej transakcji, co miało być na drugi dzień zwrócone. Gdy wszyscy odmówili, on się nie wahał podpisać weksla. Naturalnie, jego imię otworzyło kasę banku. Starał się wywdzięczyć za pomoc, to książkę ofiarował, to służył protekcją, najchętniej jednak służył pomocą duchową i powierzał rękopisy do przejrzenia. W Warszawie, gdzie było więcej sióstr, czytywał nieraz wyjątki z ,Życia Pana Jezusa", albo z pracy o Konnersreuth ${ }^{78}$. Ile razy była we Lwowie Matka Małgorzata, zawsze nas odwiedzał; przygotowałyśmy wtedy pomarańcze krajane w plastry i posypane cukrem i ciastka francuskie $z$ kremem. Bardzo lubił rozmawiać o polityce i dawał nam Boże naświetlenia. Zważywszy, że miałyśmy tylko jeden pokój, odwiedziny tak dostojnego gościa, były $z$ jego strony niemałą ofiarą.

Mistyk, filozof, mniej zajmował się prawnymi sprawami, od tego miał kanoników, wiedziałyśmy o tym. Raz w Wielką Sobotę (1922 r.) nie otrzymałyśmy w jednym kościele Komunii świętej, bo nie rozdawano jej tam wcale. Nie mogłyśmy potem nigdzie znaleźć. Dwie siostry zrezygnowały i wróciły do domu, Matka Małgorzata ze mną postanowiłyśmy prosić Pasterza. Pozwolił, ale potem kanonik zwrócił mu uwagę, że to nie jest praworządnie. Za kilka lat Matka M[ałgorzata] była ciężko chora, ale już kryzys minął, Matka Teresa ${ }^{79}$ poszła prosić Ekscelencję o Komunię św. dla niej, ponieważ Arcybiskup łacińskiego obrządku odmówił. $\mathrm{Z}$ uśmiechem przyjął nas i powiedział: „Chytre jesteście, myślicie, że wam pozwo-

${ }_{77}$ Piotrowicz Wiktor (1867-1931), święcenia kapłańskie w 1892 r. we Lwowie w obrządku ormiańskokatolickim, 1892-1903 wikariusz par. Czerniowce, 1903-1914 wikariusz parafii katedralnej we Lwowie, kanonik gremialny Kapituły Katedralnej i kanclerz Kurii Arcybiskupiej we Lwowie, 1914-1931 prowadził studia armenistyczne. Zmarł 15 IV 1931 r. we Lwowic. T. Zale ski, Slownik biograficzny, s. 86.

${ }^{-8}$ J. Teodorowicz, Zjawiska mistyczne i ich thumaczenie, Poznań 1933.

${ }^{-9}$ Kalkstein Teresa (1888-1980), do Zgromadzenia ss. Zmartwychwstanek wstąpiła w 1911 r., mistrzyni sióstr alumnatek, dyrektorka Seminarium Nauczycielskiego $\mathrm{w}$ Warszawie, przełożona polskiej prowincji Zgromadzenia, autorka publikacji historyczno-biograficznych. AAK, Relacja pisemna s. Tarsylli Krymowskiej CR, Kęty 25 IX 2998 r., bsygn. 
lę, bo nie tęgi jestem w prawie, ale kto inny mnie wyręczy" i przysłał kanonika, który wythumaczyl, że choć wschodnie ryty nie obowiązuje nowy kodeks, to jednak co do W[ielko]sobotniej Komunii u nich nie wolno poza Mszą św. przyjmować. Natrząsał się z nas jeszcze nieraz, ale w tym było tyle życzliwości.

Arcybiskup współczuł nam, że we Lwowie było nas tylko dwie, że nie możemy mieć normalnego życia zakonnego i raz po raz czynił nam propozycje i dawał w domu ormiańskim mieszkanie, ale zawsze warunki tych mieszkań były nie do przyjęcia, zwłaszcza, że nabawiłam się stałej niedomogi serca i nerek. Sam lubiący się leczyć i umiejący prowadzić kuracje, wciąż mnie proponował różnych lekarzy i kuracje, ale nie korzystałam $z$ nich, bo nie zawsze były realne.

Gdy Arcypasterz coś pisał do druku, to korekta była właściwie nowym artykułem, co wywoływało rozpacz wydawcy, zwłaszcza, że pismo miał nieczytelne. Na stole jego leżał stos kartek zapisanych różnych rękopisów, w których trudno się było komukolwiek zorientować. Nieraz cenny rękopis zgubił. Matka Małg[orzata] mawiała: „Ekscelencjo, wszystko powierzę duszy, ale nigdy rękopisu” i starała się usuwać go sprzed oczu autora.

Bardzo wiele pomocy miał od p[ani] Heleny Skolimowskiej ${ }^{80}$, kongreganistki, uwielbiającej go bezkrytycznie, mierzącej wartość każdego stosunkiem do Arcybiskupa. Był jej bardzo wdzięczny, ale nieraz ta adoracja go męczyła, był nią skrępowany, ponieważ ona $\mathrm{z}$ wielkiej czci nigdy nie wyraziła jakiegoś zdania negatywnego, jak to miały czelność czynić zmartwychwstanki. Cicho nam zazdrościła, mimo wielkiej przyjaźni, jaka ją z nami łączyła. Nigdy nie odważyła [się - J.W.] prosić go o spowiedź, choć jej pragnęła. Lubił szczerość i prostotę, wolał ,,bezczelność" s. Barbary - jak się wyrażał z uśmiechem - niż niedomówienia, pod którymi czuł, że się coś ukrywa. Bezczelnie też prosiłam go o każdą wydaną książkę dla siebie i Matki Małgorzaty, ostatnią dał mi na łożu śmierci „Kazania radiowe"81 i drżącą ręką zmienionym pismem podpisał: „Z błogosławieństwem - Teodorowicz”.

Nazywał mnie i „Raubritter"82, gdyż umiałam wydobyć z niego medytacje osobiste i szybko je przepisać. Nieraz noc poświęcałam. Było to wtedy, gdy do Lwowa $\mathrm{z}$ Warszawy przyjeżdżałam na jeden dzień. Niby groził, a był zadowolony, że duszy to się może przydać. Tak powstał cenny zbiorek: „Z Chrystusem Jezusem"83. Pisał je w żółtym zeszycie, którego nie znaleziono po śmierci; ktoś wspomniał, że kazał spalić, bo tam były różne osobiste porachunki. Między innymi plan dnia. A więc była i godzinna adoracja popołudniu i czytanie św. Teresy ${ }^{84}$ i Listów św. Pawła.

${ }^{80}$ Osoba niezidentyfikowana.

${ }^{81}$ J. Teodorow icz, Kuszenie Chrystusa. Wielkopostne konferencje radiowe, Kraków 1938.

${ }^{82}$ Niem.: rycerz rozbójnik.

${ }^{83}$ J. Teodorowicz, Z Chrystusem Jezusem. Rozważania, Kraków 1947.

${ }^{84}$ Św. Teresa z Avila (1515-1582), hiszpańska karmelitanka, mistyczka, reformatorka zakonu, kanonizowana w 1622 r., doktor Kościoła, autorka dzieł teologicznych m.in.: Droga doskonalości (1575-1570), Twierdza wewnętrzna (1577). 
Arcybiskup był dlatego tak łaskaw, bo czuł się mało rozumianym dokoła, a Bóg dał nam tę łaskę, że wyczuwałyśmy jego mistyczną duszę. Dlatego też tak chętnie bywał i u Sacré Coeur, gdyż Matki rozumiały Go również. Nieraz na tę samotność żalił się przed Matką Małg[orzatą]. Nie rozumieli go w polityce, wciąż posądzając, że należy do Endecji; było mu to bardzo przykro, nie rozumiał go i Arcybiskup Twardowski ${ }^{85}$, choć obaj się wzajemnie czcili. Arcyb[isku] Teodorowicz mówił, że choć lepiej rozumiał się z Arcyb[iskupem] Bilczewskim, to jednak wyżej w świętości stawia Twardowskiego. Za to bardzo blisko był $z$ Biskupem Lisowskim $^{86}$, a złączyła ich i cześć dla Teresy Neuman[n] ${ }^{87}$. Najmniej rozumieli go właśni księża. Jednych raziła jego wielka delikatność, która zamykała mu usta, gdy spotkał się ze sprzeciwem i nietaktem podwładnego. Ks. P[iotrowicz] mawiał: „Jak coś zbroiłem, to arcyb[iskup] Isakowicz ${ }^{88}$ natarł mi uszu, zgromil, a ja hrym do kolan i wszystko dobrze, a arc[ybiskup] Teodorowicz nic nie powie, ale drugi raz nie poprosi, to męczy". Arcybiskup najwięcej zaufania okazywał ks. Isakowiczowi i najwierniejszą miał w nim pomoc, która ustała, gdy go zrobił proboszczem w Stanisławowie ${ }^{89}$. Księża zarzucali mu, że za mało troszczy się Ormianami, ale Arcybiskup za wielkie miał horyzonty, a Ormianie dawali sobie rady.

Najtrudniejsza była sprawa z klasztorem ss. Benedyktynek orm[iańskich]. Potrzebował reformy, ale ona się nie udawała, bo w ostatecznym razie wszystko rozbijało się o przedobre serce Pasterza, który nie chciał podpisać wyroku na przeflancowanie sióstr do innych klasztorów. Nieraz gniewał się na nich i mnie używał za

${ }^{85}$ Twardowski Bolesław (1864-1944), święcenia kapłańskie w 1886 r. we Lwowie, 1888-1895 prefekt w Seminarium Duchownym we Lwowie, 1895-1901 kanclerz Kurii Metropolitalnej tamże, 1902-1918 proboszcz par. Tamopol, 1918-1923 biskup pomocniczy archidiecezji lwowskiej i rektor Seminarium Duchownego, 1923-1944 metropolita lwowski. Zmarł 22 XI 1944 r. we Lwowie. J. Wołczański, Twardowski Bolesław, [w:] Slownik Biograficzny Katolicyzmu Spolecznego w Polsce, t. 3, pr. zbior., Lublin 1995, s. 154 $-156$.

${ }^{86}$ Lisowski Franciszek (1876-1939), święcenia kapłańskie w 1898 r. we Lwowie, 1898-1902 studia specjalistyczne w Rzymie uwieńczone doktoratami fjlozofii i teologii, 1902-1903 wikariusz par. Złoczów, 1903-1904 wikariusz katedry iwowskiej, 1903-1905 katecheta gimnazjalny we Lwowie, 1905-1909 katecheta w Brodach, 1909-1913 katecheta we Lwowie, 1911-1912 podróż naukowa po Europie, w 1912/13 katecheta gimnazjalny we Lwowie i zastępca prof. teologii dogmatyczncj na Wydziale Teologicznym Uniwersytetu Lwowskiego, w 1912 r. uzyskał tamże habilitację, 1913-1933 profesor teologii dogmatycznej tamże, 1917-1919 dziekan fakultetu teologicznego, 1919-1921 prodziekan, 1920-1923 wicerektor Seminarium Duchownego we Lwowie, 1923-1933 rektor, 1928-1933 biskup pomocniczy archidiec. lwowskiej, 1933-1939 biskup diecezjainy w Tarnowie. J. Wołczański, Wydzial Teologiczny, s. 235.

${ }^{87}$ Teresa Neumann (1898-1962), Niemka, od 1926 r. w czasie Wielkiego Postu na jej ciele pojawiały się stygmaty.

${ }^{88}$ Isakowicz Izaak Mikołaj (1824-1901), święcenia kapłańskie w 1848 r. we Lwowie w obrządku ormiańskokatolickim, 1848-1849 wikariusz par. Tyśmienica, 1849-1863 wikariusz par. Stanisławów, 18631865 kapelan wspólnoty ormiańskiej w Suczawie, 1865-1882 proboszcz par. Stanisławów, 1882-1901 arcybiskup lwowski, znakomity kaznodzieja, społecznik i filantrop, polski patriota. T. Zaleski, Biskup ormianski Izaak Mikolaj Isakowicz, passim.

${ }^{*}$ Stanisławów - miasto wojewódzkie w Małopolsce Wschodniej. Funkcjonowata tam parafia ormianskokatolicka p.w. Niepokalanego Poczęcia NMP z obrazem Matki Bożej Łaskawej. 
posła. Raz w czasie Targów Wschodnich ${ }^{90}$ siostry mnie zawezwały, by im wyrobić dyspensę u Pasterza, by mogły pójść z uczennicami. Arcybiskup wysłuchał i rzekł ze śmiechem: „Po co udają, że chcą iść dla opieki dziewczynek, one same chcą się przewietrzyć" i pozwolil, choć wtedy obowiązywała papieska klauzula.

Zawsze w drugi dzień świąt czy to Bożego Narodzenia, czy Wielkiejnocy, po nabożeństwie szedł do klasztoru $z$ życzeniami. Raz zerwał się do energicznej reformy, sam dawał rekolekcje, $\mathrm{O}$. Kwiatkowskiemu $\mathrm{CR}^{91}$ polecił ich dokończenie i spowiedź, wyznaczył komisarza Dominikanina, ale potem inne sprawy go pochłonęły. To znowu umieścił tam swą penitentkę, świątobliwą wdowę z Wilna p[anią] Miłkowskąa ${ }^{92}$, przygotowując ją na reformatorkę; tymczasem w czasie rekolekcji przed obłóczynami umarła na atak sklerotyczny. Bardzo się przejął tą śmiercią i tym, co po niej nastąpiło. Oto w tydzień potem jestem u Pasterza i spotykam jakiegoś Ojca T[owarzystwa] J[ezusowego]. Gdy ten gość wyszedł na górę, a Ekscelencja mi opowiada, co następuje. Ten Jezuita przyjechał umyślnie z Wilna dowiedzieć się o szczegóły śmierci pani M[iłkowskiej], która była jego penitentką. Otóż druga jego penitentka mająca pewien kontakt $z$ duszami czyśćcowymi przyszła w dzień nazajutrz po śmierci p[ani] M[iłkowskiej], o której to śmierci jeszcze nikt nie wiedział i mówi: „Ukazała mi się p[ani] M[iłkowska] i prosiła: «Idź do naszego ojca spowiednika, proś, aby się modlił, gdyż inne są drogi i sądy Boże. Muszę w czyśćcu pokutować za ...» i tu wymieniła po łacinie winę znaną tylko spowiednikowi. Ojciec T[owarzystwa] J[ezusowego] mówił, że ile pokut sobie zadała, ile łez wylała nad tym grzechem. Arcybiskup był bardzo przejęty, bo go wszelkie komunikacje $z$ tamtym światem bardzo obchodziły.

Pamiętam, jak go w czasie pierwszej wojny poruszyły widzenia p[ani] T.; unosił się nad jej prostotą, która widziała miejsce swe na ołtarzach. Dopiero Matka Małgorzata powiedziała mu: „Ekscelencjo, św. Teresa widziała miejsce dla siebie w piekle, a ona widzi ołtarz - przecież to pycha”. Odtąd przestał się tą sprawą zajmować i uznał słuszność opinii matki.

Chętnie też chodził do klasztorów kontemplacyjnych, by z zakonnicami porozmawiać o stanach nadzwyczajnych. Raz był w Karmelu lwowskim i Matki prosiły go o kazanie na uroczystość św. Teresy od Dz[ieciątka] J[ezus]. Zgodził się, ale powiedział: „Cóż ja więcej wam mogę powiedzieć o tej gadule, wszak ona wszystko wygadała o sobie". Cenił ją, ale więcej pociągały go święte, które prze-

\footnotetext{
${ }^{90}$ Targi Wschodnie we Lwowie - coroczna wystawa przemyshu polskiego i zagranicznego $\mathrm{w}$ latach 1921-1938.

${ }^{9 t}$ Kwiatkowski Władysław (1879-1954), święcenia kaplańskie w 1903 r. w Rzymie w Zgromadzeniu Księży Zmartwychwstańców, dr filozofii i teologii, 1906-1911 wykładowca w Kolegium św. Stanisława Kostki w Chicago, 1911-1912 wykładowca w kilku kolegiach polskich w USA, 1912-1926 duszpasterz polonijny w USA, 1928-1931 rektor alumnatu we Lwowie, 1933-1938 rektor papieskiego Kolegium Polskiego w Rzymie, 1938-1943 asystent generała Zgromadzenia, 1943-1947 kierował Zgromadzeniem, później postulator generalny, autor artykułów teologicznych, historycznych, filozoficznych i kanonistycznych. B. Micewski, Kwiatkowski Wladyslaw, [w:] EK, t. 10, red. zbior., Lublin 2004, kol. 304-305.

${ }^{92}$ Osoba niezidentyfikowana.
} 
żywały stany niezwykłe. Dlatego tak się interesował Teresą Neuman[n]. Nie zapomnę, $z$ jakim przejęciem mówił o niej nam w Warszawie po powrocie $z$ Kennersreuth $^{93}$. Unosił się nad jej prostotą dziecięcą, nad jej duchem apostolskim, który ją pobudzał do zastępczych cierpień. Widział ją w ekstazie krwawej i rzekł: „To jest coś cudownego". Teresa powiedziała mu, że jest miły Bogu. Żeby pisał z większą prostotą i wciąż tak nie poprawiał (istotnie to była mania jego, która nie dozwalała mu kończyć dzieła). Powiedziała mu raz: „Idą na Polskę straszne czasy”, ale więcej nie chciał powiedzieć, choć zdaje się ona mu więcej powiedziała. Walczył też o nią gorliwie, że aż nadwerężył do reszty swe i tak niemocne zdrowie. Cała kampania z O. Siwkiem ${ }^{94}$ kosztowała go bardzo $^{95}$, zwłaszcza następujące zdarzenie, o którym opowiadał nam ks. Bogdanowicz. Ks. Bogdanowicz był w Rzymie w czasie tej polemiki, już po wydaniu polskiej książki: „Zjawiska mistyczne”. W rozmównicy klasztoru, gdzie pił kawę po Mszy świętej, spotkał się z jednym Ojcem T[owarzystwa] J[ezusowego], który opowiadał, że O. S[iwek] wnosi do Papieża memoriał, wykazujący herezję w wywodach Arcybiskupa $\mathrm{z}$ wnioskiem, by to dzieło dostało się na indeks. Ks. Bogdanowicz udał obojętność i dowiedziawszy się dokładnie o wszystko, czynił kroki, by do tego nie doszło i postarał się u niemieckich uczonych o dobrą replikę. Sprawę tę odchorował Arcypasterz. Również bardzo odczuł, że na tomistyczny kongres poproszono obok niego i ks. Siwka (w Poznaniu) ${ }^{96}$. Naturalnie odmówił, bo to był nietakt. Ale miał za złe ks. Adamowi, że sam reagował zbyt żywo. Nazwał go żółtodziobem. Mimo, że nie wszystko pochwalał w posunięciu tego kanonika, jednak cenił jego świątobliwość i gorliwość o dusze i gdy we Lwowie Kuria łacińska nieprzychylnie odnosiła się do ks. Adama za popieranie dziennej Komunii bez częstej spowiedzi, prosił mnie, gdy raz szłam do Arcyb[iskupa] Twardowskiego, by wykazać wszystkie zalety i zasługi ks. Adama, co z radością uczyniłam, będąc jego wielbicielką.

Ks. Arcybiskup był za łatwowierny i zbyt miękkiego serca, a z drugiej strony, widząc brak księży o[brządku] orm[iańskokatolickiego], zbyt łatwo przyjmował różnych eksów ${ }^{97}$. W kapitule bywali i eks-Jezuici i eks-Misjonarze, eks-Bernardy-

${ }^{93}$ Kennersreuth - wioska w Bawarii, miejsce zamieszkania Teresy Neumann.

${ }^{94}$ Siwek Pawel (1893-1986), święcenia kaplańskie w 1922 r. w Zakonie oo. Jezuitów, dr filozofii i teologii, 1916-1919 wykładowca matematyki w gimnazjum w Chyrowie, 1923-1924 wykładowca psychologii w studium zakonnym w Nowym Sączu i 1929-1931 analogicznie w Krakowie, 1931-1939 analogicznie na Uniwersytecie Gregoriańskim w Rzymie, 194-1946 wykładowca w Faculdades Católicas w Rio de Janeiro (Brazylia), 1946-1960 analogicznie na Uniwersytecie Fordham w Nowym Jorku, 1960-1975 analogicznie na Uniwersytecie Laterańskim w Rzymie, autor wielu prac naukowych z dziedziny filozofii oraz psychologii. Siwek Pawel, [w:] Encyklopedia wiedzy o jezuitach na ziemiach Polski $i$ Litwy 1564-1995, red. L. Grzebień, Kraków 1996, s. 619.

${ }^{95}$ O. Pawel Siwek polemizując z książką abp. Teodorowicza na temat zjawisk mistycznych, opublikował własne prace: Kennersreuth $w$ świetle nauki i religii (Kraków 1931), Metody badań zjawisk nadprzyrodzonych. Problem Kennersreuth (Kraków 1933).

${ }^{96}$ Międzynarodowy Kongres Tomistyczny odbył się w 1934 r. w Poznaniu.

${ }^{97}$ Nawiązanie do duchownych zmieniających przynależność zakonną na diecezjalną lub inkardynujących siç do innych diecezji. 
ni, eks-Zmartwychwstańcy itd. Chciał ratować dusze, nie zawsze jednak dobrze na tym wychodzit. Raz musiał do Rzymu pisać o zwolnienie z subdiakonatu jednego eksa, bo się przekonał, że nie jest zrównoważony psychicznie (łagodnie oceniając).

Arcybiskup nie był mile widziany przez sanację, znane było jego potępienie wyprawy Kijowskiej i inne fałszywe posunięcia Marszałka i jego kliki. Zbyt radykalizujący rząd, w konkubinatach żyjący ministrowie, nie mogli spodziewać się poparcia ze strony Arcybiskupa. Tym się też thumaczy przykrości, jakich doznał przy swoich kazaniach radiowych ${ }^{98}$. Rząd przepraszał pewne koła za wypowiedzi Biskupa zwrócone przeciw deprawowaniu duszy polskiego ludu. Bolało go i to, że Episkopat nie stanął z należytą jednością przeciw temu postawieniu sprawy. Ale w takich razach tym więcej zwracał się do modlitwy, tym bardziej zrywal więzy i cieniutkie nici, wiążące go jeszcze z polityką i światem.

Kto tak dawno znał arcybiskupa jak my, mogłyśmy widzieć to stopniowe odkrywanie się. Zwłaszcza uderzyła mnie ta zmiana w roku 1937 w Rabce ${ }^{99}$. Przyjechałam tam na dzień tylko dla zobaczenia się z Nim. Już wtedy nie mieszkał w Warszawie, więc bardzo rzadko miałam sposobność korzystać z Jego wskazówek. Przed obiadem rozmawiałam z nim w rozmównicy i wtedy rzekł: „Siostro, już tak pragnę odejśćc, już bardzo tęsknię do Chrystusa, już mnie ten świat męczy”. Po obiedzie obserwowałam go w czasie godzinnej adoracji w kaplicy ss. Nazaretanek (zawsze w swych podróżach kuracyjnych stawał w klasztorach, tak w Polsce, jak za granicą). To oderwanie malujące się na twarzy, te oczy zatopione w tabernakulum, zostaną na zawsze w pamięci; czułam, że to ktoś, kto odchodzi. „Ile to spokoju dla duszy w akcie oddania się Bogu bez względu na wszystko" - tak jeszcze powiedział.

Potem widziałam go jeszcze raz w maju 1938 roku; wtedy zaprosił na obiad, a ostatni raz we wrześniu. Już nic nie mówił o sprawach bieżących, tylko o swym niemieckim dziele o zjawiskach mistycznych ${ }^{100}$. Wyrażałam mu podziw dla tej książki i zasięgu dobroczynnego działania jej. Oświadczył, że chce ją na polski język przetłumaczyć: „To już mam prawie gotowe”. - „Więc siostra odwołuje już, że to pokusa mnie kazała zająć się Teresą, by nie kończyć dzieła o Chrystusie Panu?" (istotnie mu tak raz powiedziałam). A ja przeprosiłam za tamto powiedzenie: „Wiele, wiele dobrego ta książka zrobić powinna i Pan Jezus Mu będzie wdzięczny, że Ekscelencja broni Jego sprawy”. Uśmiechnął się i rzekł: „No, nareszcie siostra to uznała". Nazajutrz spowiedź i potem juź ujrzałam go na marach.

${ }^{98}$ Kazania te wygłosił abp Teodorowicz podczas Wielkiego Postu 6 III, 13 III, 20 III, 27 III i 10 IV 1938 r. w Warszawie, a transmitowane były przez Polskie Radio. Przypomniała je w 2007 r. Fundacja Kultury i Dziedzictwa Ormian Polskich w formie płyty CD: ,Arcybiskup ormiański Józef Teodorowicz. Wybitny polski kapłan, kaznodzieja i mąż stanu. Oryginalne nagrania z 1938 r. pięciu kazań Arcybiskupa wraz z jego biogramem".

${ }^{99}$ Rabka - znany kurort położony u styku Gorców i Beskidu Wyspowego oraz Pasma Podhalańskiego.

${ }^{100} \mathrm{~J}$. Teodorowicz, Kennersreuth im Lichte der Mystik und Psychologie, Salzburg-Leipzig 1936. 
Jeszcze z czasów warszawskich przypomina się kilka szczegółów. Gdy mieszkał na Miodowej, kilkakrotnie sekretarzowałam mu, podziwiałam jego opanowanie, boć Rózia nieraz przeszkadzała dla błahych powodów. Nigdy się nie zniecierpliwiał, nie odburknął, zawsze z uśmiechem wysłuchał jej kłopotów gospodarskich.

Gdy przychodził na Żoliborz z nauką, długo potem rozmawiał w rozmównicy, biadał nad przepracowaniem $\mathrm{s}$. Amaty i radził jej oszczędzać się, a mnie raz powiedział: „Siostra względem s. Amaty ma spełnić rolę żony ministra Bilińskiego ${ }^{101}$, która $\mathrm{w}$ czasie spoczynku męża nikogo nie dopuszczała do niego i znana $\mathrm{z}$ tego była w całym Wiedniu, ale i z tym się liczyli inni ministrowie".

Raz po kolacji, staruszka nasza s. Scholastyka ${ }^{102}$, zapragnęła się wyspowiadać u Arcybiskupa. Był to już czas, gdy chorował na serce i trudno mu było chodzić po schodach. „A, dobrze" - powiedział, odsunął obrus, podparł się ręką, odwrócił twarz od niej. „Proszę” - powiedział. Usunęłyśmy się prędko, dusząc od śmiechu, bo to było i wesołe, i rozczulające w swej prostocie. Potem jeszcze jedna siostra się wyspowiadała, ale ta miała wątpliwości, czy bez kratek jest ważne. Arcybiskup nigdy przez kratki nie spowiadał u siebie.

W listach jego, obok głębokiej myśli, jest zawsze coś humorystycznego. I tak raz pisze do M. Małgorzaty: „Podobno Radziwiłłówna chce inwazję uczynić na moje medytacje”. W innym do innej siostry: „Starajcie się wybrać Matkę Małgorzatę na Generalną, bo inaczej ja do Rzymu pojadę". Napiszcie do Matki, aby przypadkiem nie zrzekła się generalstwa i nie przyjechała do Lwowa, bo wtedy on uciekłby do domu, gdyż jeśli z daleka egzekwuje Jego skrypta, cóż by to było na miejscu.

Gdy Matka Małgorzata po powrocie z Ameryki przyjechała do Lwowa, przygotował wystawę swoich skryptów i pokazał, co za ten czas zrobil, przy tym miał minę uczniaka, który urządza „kawał”. Trudno mi dziś z pamięci wydobyć te wszystkie szczegóły.

Zwykle bardzo łatwo przyjmował zaproszenie na jakąś konferencję. Straż honorowa przy katedrze ormiańskiej zainicjowała w rok 1919 nocne adoracje. $\mathrm{Na}$ pierwszej On przemawiał, wskazując cel tego nabożeństwa.

${ }^{101}$ Biliński Leon (1846-1923), dr praw, w 1868 r. habilitacja z ekonomii społecznej na Uniwersytecie Lwowskim, 1868-1892 profesor ekonomii a potem umiejętności politycznych na Uniwersytecie Lwowskim, w 1878/79 rektor uczelni, od 1882 r. członek PAU, 1892-1895 prezydent generalnej dyrekcji austriackich kolei państwowych, od 1883 r. poseł do Rady Państwa w Wiedniu, 1895-1897, 1909-1910 i 1912-1915 minister skarbu, 1900-1909 dyrektor Banku Austro-Węgierskiego, 1911-1912 i 1915-1917 prezes Koła Polskiego w parlamencie wiedeńskim, VIII-XI 1919 r. minister skarbu w gabinecie Ignacego Paderewskiego, 1919 1923 przebywał w Wiedniu; w polityce był zwolennikiem opcji austrofilskiej oraz inicjatorem Naczelnego Komitetu Narodowego i Legionów po stronie państw centralnych. Zmarł 6 VI 1923 r. w Wiedniu. S. Głąbiński, Biliniski Leon, [w:] Polski Slownik Biograficzny, t. 2, red. zbior., Kraków 1936, s. 97-98.

${ }^{102}$ Baranowska Scholastyka (1863-1943), do Zgromadzenia ss. Zmartwychwstanek wstąiła w 1910 r., m.in. przełożona domu zakonnego w Zakładzie św. Anny w Warszawie, prowadziła ochronkę dla sierot, odwiedzała biednych i chorych. Zmarła w 1943 r. w Warszawie. AAK, Relacja pisemna s. Tarsylli Krymowskiej CR. Kęty 25 IX 2998 r., bsygn. 
Gdy w seminarium państwowym urządzono obchód Patronki, jaką była Najśw[iętsza] Panna, przyjął moje zaproszenie i w kościele Sakramentek ślicznie przemówił, wykazując o konieczności cząstki Maryi w życiu nauczycielki.

To samo $\mathrm{z}$ łatwością dał się zaprosić do bursy Torosiewicza, zwłaszcza, że bardzo cenił dyrektora Fleischmana ${ }^{103}$.

Nieraz jednak nie miał ochoty czy sił i byle pozorem chciał się wymówić i wtedy opozycję spotykał u matki, która intuicją wiedziona wiedziała, kiedy nie może, a kiedy nie chce i w tym ostatnim wypadku zniewalała go do podjęcia przemówienia, do dotrzymania danego słowa. Np. byłam świadkiem, jak Arcybiskup kazał dać znać Dominikanom na dwie godziny przed akademią w Kasynie na cześć świeżo kanonizowanego św. Alberta Wielkiego ${ }^{104}$, że jest chory i nie pojedzie. Byłam wtedy u matki, staruszka poszła na górę, zbadała sytuację i nie pozwoliła iść do klasztoru, uważając, że lekkie podrażnienie miedniczek nerkowych nie jest dostateczną racją do czynienia takiego zawodu w ostatniej chwili. Arcybiskup zaś słuchał swej matki, którą nazywał „Panią dobrodziejką”. Ona zaś mówiła: „U mnie jest tylko synem, arcybiskupem jest na górze" (mieszkała bowiem na dole w pałacu). Codziennie pod wieczór przychodził do niej na rozmowę lub grał w karty $i$ halmę ${ }^{105}$, tak manewrując, by ona wygrała. Było coś wielkiego i wzruszającego w odnoszeniu się jego do matki. Tyle czci, tyle ciepła i tkliwości. Gdy staruszka zaczęła zapadać, postarał się, że w pałacu zamieszkała s. Antonina ${ }^{106} \mathrm{z}$ Rodziny Maryi. Zajęła się gospodarstwem, co nie było łatwe, bo staruszka nawet $\mathrm{z}$ lóżka rządziła, a kucharka i lokaj widząc, że nie mogą tak okradać jak dotąd, uczynili siostrze czyściec prawdziwy. Gdy gorzej się czuła, a on musiał wyjechać, prosił mnie, bym mu donosiła o stanie zdrowia i ostrzegła przed niebezpieczeństwem.

Taka chwila przyszła w roku 1928 we wrześniu. Trzeba było, nie czekając na Arcybiskupa, udzielić św[iętych] Sakramentów. Namówiła staruszkę s. Paula ${ }^{107}$. Pani Teodorowiczowa ${ }^{108}$ głęboko wierząca należała jednak do tego pokolenia, które nie rozumiało, by można fatygować księdza. Ale s. Paula powiedziała, że zaczynamy nowennę, a do tego trzeba być u Komunii świętej. Dała się namówić i wieczorem $\mathrm{w}$ asyście kilku sióstr przyjęła Sakramenta święte z rąk ks. Piotrowicza.

\footnotetext{
${ }^{103}$ Osoba niezidentyfikowana.

${ }^{104}$ Św. Albert Wielki (1193/1205?-1280), dominikanin, filozof i teolog, doktor Kościoła, kanonizowany w 1931 r. przez Piusa XI.

${ }^{105}$ Halma - gra planszowa rozgrywana na kwadratowej szachownicy złożonej z 256 pól. W grze mogą uczestniczyć $2-4$ osoby. Zadanie polega na przeprowadzeniu wszystkich pionków zgromadzonych po stronie danego zawodnika do przeciwległego narożnika.

${ }^{106}$ Osoba niezidentyfikowana.

${ }^{107}$ Zuber Paula (1878-1950), do Zgromadzenia ss. Zmartwychwstanek wstapiła w 1900 r., jako absolwentka kursu pielęgniarskiego opiekowała się chorymi m.in. w domach prywatnych, we Lwowie zajmowała się pielęgnacją matki abp. Józefa Teodorowicza. Zmarła w $1950 \mathrm{r}$. w Kętach. AAK, Relacja pisemna s. Tarsylli Krymowskiej CR, Kęty 25 IX 2998 r., bsygn.

${ }^{108}$ Teodorowicz Gertruda z Ohanowiczów (1838-1930), matka pasterza archidiecezji ormiańskokatolickiej we Lwowie, zmarła 13 III 1930 r. tamże, pochowana na Cmentarzu Lyczakowskim. ALOL, [Księga pogrzebów, pole 52-54], bmr, rps, bsygn.
} 
W nocy przyjechał zaalarmowany Arcybiskup. Staruszce podobała się ta uroczystość (miała ponad 90 lat) i chciała przez całą nowennę takiej procesji i Komunii wieczorem. Dostojny syn pozwolił i sam ją przynosił, a gdy s. Paula się zamarudziła, to lokaj po nią przychodził.

Gdy $\mathrm{p}$ [an] Michał był chory, arcybiskup nie miał odwagi powiedzieć o tym matce, prosił o to M. Małgorzatę. Byłam chora, gdy matka umarła $1929 \mathrm{r}^{109}$, ale siostry mówiły, że [arcybiskup - J.W.] przez uchylone drzwi patrzył, jak ją wynoszono do kościoła, a łzy mu leciały z oczu. Pięknie i rzewnie odpisał na moją kondolencję.

Matka znała dystrakcję i zapominalstwo syna. Skoro więc szedł na jakie zebranie pilnowała, czy ma czystą chustkę, rękawiczki, order, lepszą piuskę itd., przy tym mile gderała, choć któraś $z$ nas była obecna i jeszcze coś pisała.

Po jej śmierci zamieszkała daleka krewna $\mathrm{z}$ małą kuzyneczką, by prowadzić gospodarstwo; ponieważ to była osoba nietaktowna, nieraz mi się radził, co $z$ nią zrobić, gdyż bardzo starannie unikał tego, co mogło cień pozoru nawet rzucić na jego cześć kapłańską. W pierwszych latach Biskupstwa padł ofiarą kampanii oszczerczej znanego pisma „Monitor"110, które tylko żyło skandalami i oszczerstwami. Obu Arcybiskupów,-tj. jego i Bilczewskiego posądzono o najohydniejsze rzeczy. Całe społeczeństwo ujęło się i „Monitor” stracił większą część prenumeratorów. Arcybiskup zachował całą godność i najzupetniejszą obojętność, jakkolwiek wewnętrznie cierpiał nad tymi brudami. Cieszył się jednak, że z Chrystusem znosi obelgi.

Dzieła: z r[oku] 1934 - „Ja tkwię w drugim tomie dzieła o Chrystusie, który będzie poświęcony Żydom. Niezadługo zamiast piuski wdzieję jarmułkę, a zamiast sutanny chałat”. Po ukończeniu „Od Jahwe do Mesjasza”"111 deputacja rabinów przyszła złożyć mu podziękowanie za obronę nadprzyrodzonego charakteru Starego Testamentu.

O Metr[opolicie] Szeptyckim tak powiedział przed śmiercią: „U niego już są objawy apostazji i umrze jako apostata". Gdy przyszli roku 1941 Niemcy do Lwowa, [abp Szeptycki - J.W.] kazał w cerkwiach śpiewać na cześć Hitlera: „Mnohaja lita" ${ }^{112}$ - zapominając, że Papież potępił hitleryzm ${ }^{113}$.

Niezapomniane są jego rozmowy o dziele: „Życie Pana Jezusa”. „To praca całego mego życia. To dhug, jaki spłacam Chrystusowi. To odpowiedź na bluźnierstwo Renana ${ }^{114}$. Chcę dać syntezę, dlatego nie będę kroczył od szczegółu do szcze-

\footnotetext{
${ }^{109}$ Błąd autorki; por. przypis 108 niniejszej edycji.

${ }^{110}$ "Monitor" - tygodnik polityczno-społeczny i literacki, ukazywał się w latach 1895-1914 we Lwowie, redaktor: Ernest T. Breiter.

${ }^{111}$ Por. przypis nr 75 niniejszej edycji.

112 Ukr.: sto lat.

${ }^{113}$ Nawiązanie do słynnej encykliki Piusa XI Mit brennender Sorge z 14 III 1937 r., potępiającej ideologię niemieckiego nazizmu.

${ }^{114}$ Renan Ernest (1823-1892), francuski pisarz i filozof, autor dzieł $\mathrm{z}$ zakresu historii religii, $w$ tym najbardziej znanego: Życie Jezusa (1863), w którym ukazał Chrystusa w ludzkim wymiarze, pomijając aspekt religijny.
} 
gółu. Pan Jezus musi być więcej znany i kochany. Muszę ukazać Jego bóstwo, nie obniżając wielkości człowieczeństwa". Jak chętnie czytał urywki, które mu się wydawały skończone. Wtedy jasność biła od jego oblicza; czytając zapominał, że ma przed sobą słuchaczy, ale obcował z Chrystusem i jak św. Tomasz musiał pytać: „Czy dobrze napisałem?" Wciąż niestety poprawiał i mówił, że w nim się sprzągł pisarz z kaznodzieją, ten ostatni najczęściej brał przewagę, to się nie podobało autorowi i dlatego poprawiał i poprawiał.

O. Smolikowski raz mu powiedział: „Ekscelencja, gdy poprawia, to psuje swe dzieło"; ojciec miał na myśli, że zatraca się świeżość bezpośredniości. Ale często zyskiwała na tym patena naukowości. M. Małgorzata znowu często mu powtarzała: „Ekscelencjo, dla chwały Bożej i dobra dusz będzie lepiej, gdy dzieło będzie mniej wycyzelowane w poprawkach, a za to skończone, niż gdy wyjdzie kilka tomów". Najpiękniejsze karty o świadomości Chrystusa są w rękopisie, czytał je, postać Zbawiciela, Syna Człowieczego, Syna Bożego, Słowa przedwiecznego tak była skreślona, że nie spotykałam tego w żadnej biografii. Najwięcej zbliżone są karty z ,Życia Chrystusa” Adama, choć Arcybiskup o wiele szerzej i głębiej ujął, zabarwiając swym mistycznym wejrzeniem, nie mówiąc o języku.

Ogół miał żal-do Arcybiskupa, że zajął się Teresą Neuman[n], a nie pisał dzieła $\mathrm{i}$ on nieraz żałował tego. Trudno dziś ocenić, czy kierowało nim natchnienie Ducha Świętego, czy tylko jego gorliwość o sprawy mistyczne i ich należycie ocenianie. To jest już jego tajemnica, jak tajemnicą zostanie, co więcej dobrego zrobiły: czy książki o Teresie, czy tomy o Chrystusie Panu.

W pracy nad pierwszymi tomami pomagali mu między innymi ks. Klawek ${ }^{115}$, O. Fitz ${ }^{116}$ - Dominikanin, o którym mówił: ,Znakomity biblista” i którego bardzo

${ }^{115}$ Klawek Aleksy (1890-1969), święcenia kapłańskie w 1913 r. w Gnieźnie, 1913-1914 wikariusz par. Wonieście, 1914-1917 studia specjalistyczne w Münster uwieńczone doktoratem teologii, 1917-1918 kontynuacja studiów w Monachium i Wrocławiu, I-II 1918 r. wikariusz par. Granowo, II-X 1918 wikariusz par. Rydzyna, 1919-1922 wykładowca Pisma św. w Seminarium Duchownym w Gnieźnie i Poznaniu, w 1921 r. habilitacja na Wydziale Teologicznym Uniwersytetu Jana Kazimierza we Lwowie, 1923-1939 profesor Starego Testamentu tamże, 1925-1933 wykładowca języków semickich na Wydziale Humanistycznym tamże, 1925-1927 i 1933-1935 dziekan Wydziału Teologicznego UJK, 1934/35 prorektor uczelni, 1939-1941 przebywał w Rogoźnie (Wielkopolska), X-XI 1941 r. więziony przez. Niemców, XI 1941-1945 przebywał na terenie diec. tarnowskiej prowadząc tajne nauczanie i duszpasterstwo, 1945-1954 profesor Starego Testamentu na Wydziale Teologicznym UJ, 1948-1951 dziekan fakultetu, 1954-1962 wykładał biblistykę w krakowskich seminariach duchownych, 1932-1951 członek PAU, 1957-1968 czlonek PAN, od 1966 r. emerytura. Zmarł 22 XI 1969 r. w Katowicach, pochowano go w Rogoźnie. Był wybitnym biblistą i thumaczem Pisma św. na j. polski. J. Wolczański, Wydzial Teologiczny, passim; R. Zimny, Cale życie z Bibliq. Aleksy Klawek (1890-1969), Poznań 2004, passim.

${ }^{116}$ Właściwie: Fic Atanazy (1901-1943), święcenia kapłańskie w 1925 r. w Zakonie oo. Dominikanów, w 1929 r. doktorat teologii, w 1933 r. habilitacja na Wydziale Teologicznym UJ w Krakowie, 1930-1936 rektor Studium Filozoficzno-Teologicznego oo. Dominikanów we Lwowie, 1933-1936 docent na Wydziale Teologicznym UJ, 1936-1939 analogicznie na Wydziale Teologicznym Uniwersytetu Jana Kazimierza we Lwowie, 1939-1943 przebywał w Krakowie. Zmarł 13 XI 1943 r. we Lwowie. J. Wołczański, Wydzial Teologiczny, s. 205. 
chętnie widywał u siebie na wieczornej pogawędce lub szachach i nawet telefonicznie upominał się o niego, gdy ten nie przychodził w oznaczonej godzinie.

Literacką korektę pierwszego tomu przeprowadziła ś.p. S. Amata Kosowska CR. Nieraz tak intensywnie pracował, że zapadał na zdrowiu. Niektóre ustępy i cytaty przepisywały mu siostry lub wierna $\mathrm{p}$ [ani] Skolimowska. Cytaty z Pisma św. trzeba było sumiennie sprawdzać, bo Arcybiskup bałamucił je lub swoim językiem przytaczał. O. Klemens Dąbrowski ${ }^{177}$ mawiał: „To nie Mat[eusz] X ani Luk[asz] XV ale Teodorowicz XI" itp. Wiedział o tym i dlatego był wdzięczny za sumienną pomoc. Nieraz pytał, czy jakieś wrażenie jest dość z punktu literackiego cenzuralne, gdyż miał bardzo żywą wyobraźnię i wielki realizm lubiący wszystko dosadnie określać.

Co do thumaczenia Pisma św. to choć mu nie odpowiadał Szczepański ${ }^{118}$, to jednak uważał, że dla dzieła będzie lepiej, jeśli się na nim oprze.

Arcybiskup w chwilach wolnych, odpoczynku, lubił czytać lekkie powieści i literaturę dla młodzieży, lubił również rozmowy niefrasobliwe i humorystyczne. Pani Skolimowska, która odnosiła się niemal do niego $\mathrm{z}$ ubóstwianiem, nigdy nie zaczynała takich rozmów i dziwiła się, że on chętnie $z$ nami gawędzi i żartuje. Dowodziło to jego nieskrępowania się w naszym towarzystwie. Razu pewnego wprost mnie prosil, bym mu co wesołego opowiedziała, a gdym mu powiedziała, że nie mam co, wtedy rzekł: „To źle, za to ja mam”.

\section{WYPOWIEDZI ${ }^{\mathrm{b}}$ KS. ARCYBISKUPA [NA TEMAT ŻYCIA DUCHOWEGO - J.W.] W ROZMOWACH I SPOWIEDZI}

- Gdy duszy trudno udźwignąć się z życia przyrodzonego, powinna czynić wysiłek modlitwy; ten jest zawsze łatwy, a ważniejszy niż wysiłek energii, do którego tyle dusz chętniej się bierze, bo chcą czynić z siebie, a nie z Boga.

- Kto ma tyle pracy co wy w szkole, ten nie może dążyć do Pana przez skupienie mistyczne. Idąc za głosem sumienia i obowiązku, już się jednoczy z Panem, a w chwili wolnej ofiarowywać Mu prace, trudy, tęsknotę za bliższym zjednoczeniem.

- Należy się oddać w woli na wszystko, co Bóg chce z Matką uczynić i jak ogałacać ze wszystkiego. Objąć i ukochać nagą wolę Bożą bez smaków.

${ }^{117}$ Osoba niezidentyfikowana.

${ }^{118}$ Szczepański Władysław (1877-1927), święcenia kapłańskie w 1903 r. w Zakonie oo. Jezuitów, 1904-1907 studia w Instytucie Orientalnym w Bejrucie, 1907-1908 studia w Innsbrucku, 1908-1909 probacja w Tarnopolu, 1909-1915 profesor w Instytucie Biblijnym w Rzymie, 1915-1918 przebywal w Czechowicach i Krakowie, 1918-1927 profesor biblistyki na Wydziale Teologii Katolickicj Uniwersytetu Warszawskiego, 1919-1920 dziekan fakultetu, w 1927 r. miał objąć kierownictwo Instytutu Biblijnego w Jerozolimie, ale 30 V 1927 r. zmarł w Innsbrucku. Wybitny biblista, thumacz Ewangelii na j. polski. L. Grzebień, Szczepański Wladystaw, [w:] SPTK, t. 7, s. 211.

${ }^{b}$ Maszynopis w objętości pięciu stronic formatu A 4. 
- Boję się w klasztorze o fałszywy mistycyzm. W nowicjacie może być złe zrozumienie O. Semenenki, a nie ma podstaw ascezy i młoda siostra na misji nie mając czasu na kręcenie się około swej duchowości wpada w zniechęcenie i romansuje, szuka serca, które by ją odczuło.

- Jedna pani na zebraniu pytała: „Co ważniejsze: czy praca społeczna, czy wewnętrzna?” Odpowiedział: „Między jednym a drugim kierunkiem musi być utrzymana miara. Konieczną jest praca wewnętrzna $i$ ważniejszą, ale ona nie wyklucza zewnętrznej. W każdej nauce obok teorii musi być eksperyment, który ją pogłębia i utrwala. Tak samo w życiu. Gdybyśmy wciąż się wyrabiały, a nic nie robiły zewnętrznie, zamierałoby wasze życie wewnętrzne. Nie można znowu brać pracy nad siły, bo wtedy wyczerpuje się wewnętrznie. Ostrożność i wstrzemięźliwość musi stawiać wytyczne, by ustrzec się dwóch skrajności: bierności i gorączkowego czynu".

- Trzeba być przygotowaną, że pycha, zwrot na siebie, nie opuszczą aż do końca życia. Trzeba wciąż cierpieć te poruszenia natury. Droga wewn[ętrzna] to unicestwienie, upokarzanie się, do czego co godziny nastręcza się sposobność. Trzeba z nich chętnie korzystać, by wewnątrz przed Bogiem się upokarzać, nie przed ludźmi.

- Trudności w skupieniu leżą i w pracy zewnętrznej, w jej warunkach i w naszym niewyrobieniu. Trzeba dlatego korzystać z każdej chwili, by się zwrócić do Boga. Minie dzień, dwa, cztery, w których nie będzie można zebrać się wewnętrznie, ale przyjdzie piąty swobodniejszy; tym gorliwiej skorzystać $z$ tego dnia, by wyrównać zaniedbania poprzednie. Znosić mężnie ten krzyż niemożności skupienia, który krzyżuje miłość własną, chcącą, by wewnętrznie wszystko było w porządku z Wolą Bożą, a roztargnienia wskazują, jakimi jesteśmy w istocie.

- Co do stosunku z przełożoną, nie musi się wszystko mówić, bo to wytwarza drobiazgowość, ale trzeba być szczerą, otwartą, zwłaszcza, gdy ta szczerość i otwartość kosztuje, gdy zależność krzyżuje miłość własną. Starać się i kochać właśnie ten krzyż, ten trud, a wtedy ukocha się i zależność.

- Gdy dusza poznała, na jak fałszywym gruncie stała, gdy poznała korzeń zatruty, który niszczy złe uczynki, może budować spokojnie nowe życie na Chrystusie, On będzie naszą siłą, tak w pracy wewnętrznej, jak obowiązkach zewnętrznych. Tylko Mu ufać.

- Trzeba leczyć korzeń pychę woli, a nie odcinać gałęzie, np. brak umartwienia. Ono płynie z przekonania o naszej ważności i niezastąpioności. Pycha musi odbić się w ciele i stąd nieumartwienie. Nie można jej wyniszczać negatywnie, gdyż Opatrzność dała pracę, gdzie trzeba rozwijać całą energię $i$ inicjatywę, więc trzeba ją leczyć przez miłość. Niech będzie w nas to widoczne, że wszystko czynimy z woli Bożej, z miłości dla tej woli Najśw[iętszej], jako służebnice Pańskie. W Woli Chrystusowej szukać lekarstwa dla swojej woli i dlatego wśród zajęć często trzeba się zwracać do Jezusa i prosić: „Panie, nie daj mi odstąpić od Ciebie. Pa- 
nie, ratuj mnie, wspomóż mnie. Panie, pokaż w czym poszłam za głosem natury zepsutej".

- Co do przełożeństwa, to przyjmij je jako Wolę Chrystusa, nie chciałaś, nie szukałaś, broniłaś się, przedstawiłaś rację, ale teraz wszystko skończone. Zapewne da ci wiele trudności wewnętrznych, ale znoś je w duchu miłości Woli Bożej i w tym duchu naprawiaj wszystko, tylko $z$ wielkim spokojem. Umiej uszanować w drugich działanie łaski, która może jest ukryta pod zewnętrznymi upadkami.

- Bardzo często musimy poprzestać na intencji mniej doskonałej, bo do innej nas łaska nie usposabia. Nie można również ściśle odgraniczyć względu na Boga od względu na dobro duszy, bo i w udoskonaleniu własnym jest Wola Boża i z tego punktu na nie patrzeć trzeba. Szukać siły przeciw sobie w życiu zakonnym - to jest pobudka nadprzyrodzona, potem łaska się rozwija i żąda czegoś innego. Ale wtedy było wszystko w porządku i nie było winy... Nie trzeba wciąż się doszukiwać w sobie złej intencji; czynię, jak umiem najlepiej. Więcej brać te rzeczy po prostu. Nie dobrze jest tak bardzo analizować swych stanów.

- W gwałtownej chęci oskarżania się przed przełożoną z każdej nawet myśli, bardzo często może być własna koncepcja cnoty pokory. Tylko tyle jest obowiązek mówić, ile nakazuje reguła lub nakaz łaski, ale wtedy jest spokój a nie szamotanie. Jeśli z siebie chcesz więcej mówić, mogą przyjść skrupuły co mówić, a co nie itd. Pewnie, że akt oskarżenia jest krzyżem dla natury, ale pokój i porządek ważniejszy. Wnętrze duszy nie należy do przełożonej.

- W modlitwie nieraz dusza chce odpocząć, więc nie wysilać się wtedy na jakieś myśli, to nie będzie lenistwem, gdy się poddasz działaniu łaski.

- Medytacja nie jest spekulacją umysłową, fïlozoficznym roztrząsaniem prawd Bożych, bo wtedy przestaje być modlitwą. Trzeba jednak znaleźć czas na czytane duchowe, inaczej nie ma się skąd czerpać tematu do medytacji, ze siebie nie można brać.

- W modlitwie główny nacisk kłaść na wolę, by uniknąć niebezpieczeństwa zbyt dhugiego czekania na łaskę, trzeba więcej energii. Jest tyle światła, a natura niszczy zbyt dhugim zwlekaniem.

- Modlitwa jest i pracą i odpocznieniem w Bogu. Czuje się ten spoczynek to trwać w nim, trwać spokojnie, nie czuje się - wtedy pracować i myślą, i wolą.

- Na medytacji nieraz trzeba sobie pomóc racjami umysłowymi, które by wzmocniły postanowienia, ale strzec się, by w tym nie było za wiele własnego działania, by zawsze była jedność $z$ Bogiem, bo modlitwa to zjednoczenie $z$ Nim. Nieraz postanowienie przyjdzie po medytacji jako skutek modlitwy np. w formie inicjatywy, pomyśle w pracy itd. Jeżeli jest pociąg, by się więcej wpatrywać w Pana Jezusa, to iść za tym pociągiem, ale doskonale można go połączyć zastanowieniem się nad sobą, brać co się ma w duszy i podziwiać Boże działanie w duszy, Jego mądrość i dobroć. Modlitwą trzeba reagować na głos natury chcącej wszystko sobie zawdzięczać. Taki zwrot do Boga: „Ty tylko możesz uczynić to, czego pragniesz dla mnie" jest modlitwą i aktem ufności, a zarazem leczy pychę. 
- Na medytacji rozumowanie na dany temat jest jak pocieranie siarnika. Nie od nas zależy, czy on się prędzej, czy później zapali. Skoro łaska i usposobienie pobudza do uczuć i aktów woli, to by nonsensem było zatrzymywać się na medytacji i wtedy ona przestałaby być medytacją.

- Stanowczo trzeba trzymać się zasady, że medytacja to nie rozumowanie, trzeba na niej zachować swobodę i iść za tym, do czego się ma pociąg, inaczej medytacja zamieni się w męczarnię. Rozumować można każdej chwili, ale na medytacji musi być pęd do Pana Jezusa.

- Nie trzeba się zaniedbywać w pracy tępienia najmniejszego zła w sobie, ale aby to czynić nie $\mathrm{z}$ chęci podobania się sobie ale Temu, który nas powołał. Trzeba traktować tę pracę jako Wolę Bożą. Utrudzenie w tej pracy pochodzi ze złości na siebie, że nie jesteśmy takimi, jakimi chcemy być. Ale gdy przestaniemy się na siebie złościć, niecierpliwość $\mathrm{w}$ razie przekroczenia przepisów, w razie niewierności, to ta praca podjęta jako Wola Boża będzie nam miłą. Będziemy wtedy szukali okazji do upokorzenia, cieszyli się, że przez to upokorzenie damy dowód miłości Bogu. Bo to są akty pośrednie miłości Bożej, a są i bezpośrednie.

- Iść za łaską, to nie znaczy iść samemu, ale liczyć się z nią, pytać, a u nas jest taka niezależnøść, że najmniejsze ograniczenie już jest katastrofą. Trzeba pomału się w tym pokonywać.

- Są dusze, które z woli Bożej idą pomału ku Bogu i z tym się zgodzić muszą, umierając wciąż pragnieniu aby iść prędko. Miłość własna bowiem nie może znieść upokorzenia i powolnego pochodu do Boga.

- W stosunku do Pana Boga trzeba wiele prostoty; zdobywa się ją przez oczyszczenie intencji. Do objawów złej natury trzeba się wtedy przyznawać cicho, słodko, spokojnie i mówić: „Ty widzisz, o Boże, że ja chcę tylko swej woli, chcę źle, ale Ty daj mi łaskę bym chciała tylko Twej Woli". Samo wypatrywanie nędzy doprowadza do rozpaczy, trzeba od nędzy wznosić się do Pana Jezusa i rozważać Jego miłosierdzie i cierpliwość. Na modlitwie ma następować przemiana pod wpływem Pana Jezusa. Trzeba prosić, by przemienił nasze uczucie, pragnienia i myśli w swoje. Mamy być transparentem Jego właśnie przez nasze nędze.

- Gdy Pan Jezus kogo chce podnieść na wyższy stopień w modlitwie, albo w szczególny sposób prowadzić, daje to odczuć tak, że nie ma dusza wątpliwości, będzie się czuła całkiem do tego porwana. A tak w tym dopatrywaniu się szczególnych stanów - jak to jest u niektórych - może być i na pewno zwykle jest ambicja, by być traktowaną w szczególny sposób przez Boga. U ludzi świeckich taka ambicja jest względem zaszczytów, u zakonnic i dusz wewnętrznych ta sama ambicja jest co do stanów duchowych. To należy zostawić Bogu.

- Unikanie ludzi nie zawsze jest egoizmem, bo dusze wewnętrzne mają skłonność do samotności, do kontemplacji i dlatego odosobnienie jest pożądane.

- O ile obowiązki nie pozwalają na dłuższe modlitwy, to pragnienie jej i pragnienie obcowania z Panem Jezusem, zbliżenia się do Niego, już jest modlitwą. Niemożność pójścia za tym pragnieniem jest krzyżem, krzyż musi boleć. Bunt 
więc, który się budzi na tę niemożność skupienia trzeba zamienić w cierpienie nieodłączne od życia czynnego.

- Najlepsza ekspjacja, to coraz większe wewnętrzne oddanie się Bogu, coraz większa zależność od Jego łaski.

- Nie wszystkie dusze mają wrodzoną wylewność wobec bliźnich. Takie muszą sobie pomagać refleksją, trzeba sobie wypracować to wylanie wobec drugich w miłości. Zwłaszcza na modlitwie zmuszać się trzeba modlić za drugich, czynić to dla Pana Jezusa, bo to są Jego dusze, dla Niego i wymadlasz łaski.

- Nie trzeba się zmuszać trwać w uczuciu, gdy ono na modlitwie ogarnie, bo mogłoby wytworzyć skrupuły. Jak jest uczucie, można prosić o jego utrwalenie, a potem umieć znosić suszę i wiernością obowiązkom okazać wdzięczność. Jeśli nie możesz w uczuciu łączyć się z Panem Jezusem, to na polu woli szukać trzeba zjednoczenia.

- Pragnienie skupienia i modlitwy nie jest egoizmem, ani nawet pragnienie pociechy, bo dusza tym się broni przed zewnętrznością. Nawet obieranie lepszego miejsca na modlitwę nie jest egoizmem, bo tym chce się opancerzyć przeciw światu. Namiętne szukanie pociech jest jednak złem, jest despotyzmem, który występuje wobec Boga u niektórych dusz.

- Są chwile w życiu, gdy dusza przeprowadza bierny opór wobec Boga. Przestaje reagować na łaskę, bo ma jakiś ukryty żal, że nie spełnił jej pragnien. W tym już nie działa sama natura, w tym jest i pokusa szatańska, która pochodzi z najsłabszej strony, naszej samowoli. Dusza się wtedy typowo usprawiedliwia i thumaczy. Takie przejścia niech dusze nauczą bać się swej woli, bo z tej strony zawsze grozić będzie niebezpieczeństwo. Nadto taka dusza winna sobie uprzytomnić, że jej oddanie Bogu nie jest czymś, co może być lub nie może, ale że jest kwestią zbawienia. Wtedy wśród doskonałego spełniania obowiązków zewnętrznych może się taka dusza potępić, jeśli nie będzie żyła wewnętrznie.

- U dusz intelektualnych często rozumowanie przeszkadza w postępie, na to ratunek w miłości serca. Ilekroć więc taka dusza spostrzeże, że na modlitwie za wiele rozumuje, niech się zaraz zwraca do Pana Jezusa i mówi: „Panie, daj, abym Cię więcej kochała i lepiej znała”. W pokorze serca niech szuka ratunku, choć cała natura sprzeciwia się temu, ale te akty trzeba czynić przed Chrystusem. Dla Niego postępuje się w cnotach, dla Niego upokarza i to w takim stopniu, jak Mu się podoba. Stąd konieczna cierpliwość ze sobą, bo On ją ma z nami. Trzeba przynosić mu swe ubóstwo, swoją nędzę, swe niedostatki, bo na więcej nas nie stać.

- W stosunku do drugich, zwłaszcza do podwładnych, trzeba pamiętać o odpowiedzialności naszej przed Bogiem za te dusze. Na rachunku sumienia liczyć się, czy się nie dotknęło Pana Jezusa w tych duszach, czy się ich nie zraniło, czy się je zbliżyło do Chrystusa, czy oddaliło. $Z$ całą energią należy nawet $w$ drobiazgach praktykować zaparcie bez względu czy się czuje pociąg do tego, czy nie, inaczej natura weźmie górę i nie będzie można tego naprawić. Nigdy nie należy mówić do ludzi podniesionym głosem, bo wtedy natura bierze górę i łatwo powie 
się coś przykrego. To opanowanie zewnętrzne pociągnie i opanowanie wewnętrzne. Ile razy sumienie wyrzuci, że się komuś zrobiło przykrość, trzeba koniecznie zagoić rany, czy to jakim słowem, czy usługą, czy choćby upokorzeniem i przeproszeniem. Trzeba nad tym pomyśleć, jak wyrównać tę przykrość.

- Należy w ciągu pracy co godzina przynajmniej odnawiać akty oddania Panu Jezusowi: „Dla Ciebie to czynię"; to broni przed rozproszeniem. Pomoże w tym jednoczeniu strona sercowa. Zwracać się do Niego należy w każdej wątpliwości, trudności, radości. Radzić się, co On o tym myśli, co radzi, itd.

- Celem każdego aktu duszy jest uwielbienie Boga, pomnożenie Jego chwały, jeżeli więc po upadku dusza raczej odczuwa pociąg do wielbienia miłosierdzia Bożego niż do upokarzania się, powinna w tym trwać, bo bez tego i tak upokorzenie byłoby niekompletne.

- Nie należy zbyt podpatrywać siebie, czy nie szuka się przyjemności w modlitwie, gdyż w modlitwie i pracy wewnętrznej jest przyjemność dana od Boga i nie możemy się jej zupełnie pozbywać, bo to byłoby ze szkodą duszy.

- W życiu wewnętrznym trzeba ufać Bogu, że zaprowadzi Cię tam, gdzie zamierza i da odpowiednie łaski. Jeżeli wyprowadza duszę ze stanu, gdzie laski marnowała, to tym więcej da nowe i poprowadzi dalej i rozwinie łaski, byle $\mathrm{Mu}$ ufać i być wierną. Lęk, czy się nie zmarnuje na nowo, dowodzi, że dusza chce od siebie i własną siłą wszystko czynić.

- Na spowiedzi należy się zawsze szczerze oskarżać, choćby spowiednik nie rozumiał. Zapewne, że w każdym grzechu są subtelności, których nie każdy spowiednik zrozumie, które tylko nieraz sam Bóg widzi, o czym nas przekonuje sumienie, ale bez względu na to trzeba się spowiadać. Jedynie ostrożną trzeba być ze szczególnym oskarżaniem się co do roztargnień w modlitwie, bo to bardzo utrudni spowiedź, a dusza nie zawsze może je uchwycić.

- W pracy, do której się ma uzdolnienie, nie można nie czuć przyjemności, ale trzeba siebie uprosić łaskę, by ją umarzać zwrotami do Chrystusa. Wtedy, kiedy najwięcej jesteś jej oddana, na jedno oka mgnienie oderwać się, a ta praktyka już technicznie wpłynie na większą czystość w zajęciu.

- Dobrze jest przynaglać ciała do upokorzenia, kazać mu klęczeć przy modlitwie więcej i innymi aktami zewnętrznymi, by nie stawiało oporu.

- Nie zawsze możemy wiedzieć, czy mamy łaskę; wtedy, gdy najmniej czujemy jej, wtedy Pan Jezus najwięcej pracuje. Są łaski, co przychodzą i odchodzą, ale zostawiają ślad w duszy, byle by była dobra wola.

- Nie można rozgraniczyć matematycznie aktów ciała od ducha, przyrodzonych od nadprzyrodzonych, gdyż nieraz nie wiemy kiedy upadamy, a jeszcze mniej wiemy kiedy powstajemy. Dlatego nie należy poddawać się uczuciom zmysłowym, bo inaczej rozpieszcza się ciało, które i tak przez nadmierną pracę wymaga dla siebie względów. Trzeba się umartwiać wewnętrznie, zwracać do Boga, choć się nie czuje łaski. To już z punktu moralnego ma znaczenie i nie pozwolić na zacietrze- 
wianie się w pracy. Gdy Pan Bóg zsyła chorobę, to chce, byśmy się więcej oddali pracy serca, gdyż przy pracy zawodowej zaniedbujemy jej zwykle.

- Niepowodzenia wewnętrzne pochodzą zwykle $\mathrm{z}$ tego, że szukamy ratunku w sobie, nie w Jezusie. Jemu trzeba przedkładać te trudności i swe zniechęcenia, nie troszcząc się, kiedy to się zmieni.

- Nie jest wskazane myśleć o świętości w sposób teoretyczny, bo wtedy łatwo o wykarmienie miłości własnej, ale nie trzeba tracić z oczu uświęcenia swego, które polega na bardzo wiernym odpowiadaniom wymaganiom Bożym. W miarę tych wymagań, będą coraz większe ofiary.

- Gdy się czuje głód zjednoczenia z Panem Jezusem, zaspokajać trzeba aktami wiary, upokorzenia, intencji wśród pracy, zwracając się do Pana Jezusa Ukrytego w Najśw[iętszym] Sakramencie. Niezaspokojenie tego głodu męczy duszę więcej niż upadek. Jest to kierunek łaski za którym trzeba iść, pamiętając na dwie rzeczy: 1) że to jest osobne powołanie i nie należy do zwykłej wierności, więc i spowiednikowi nie musi się tego przedstawiać, tylko kierownikowi; 2) w tym pragnieniu trzeba się stosować do wymagań Bożych i tylko $\mathrm{w}$ tej mierze pragnąć, w jakiej to zjednoczenie możliwe $w$ danych warunkach. Trzeba sobie określić praktyki, które by jednoczyły i być im wiernym.

- Warunki życia nieraz niepowszednie i niezdrowe dla życia wewnętrznego trzeba przyjąć jako dopust Boży i korzystać dla pogłębienia znajomości swej nędzy i niemocy, i spokojniejszego jej znoszenia. My bowiem teoretycznie znamy nędzę, a jak się ujawni, zżymamy się. Tym częściej, tym chętniej trzeba się wtedy zwracać do Pana Jezusa właśnie dlatego, żeśmy tak niemocni, a to jest pokusa, jeśli wtedy ucieka się od Boga.

- Pokój do duszy przychodzi z przeświadczenia, że Pan Jezus Sam wyrównuje nasze braki, że przyjmuje nas takimi, jakimi jesteśmy. Właśnie w tych rzeczach najświętszych, gdy chodzi o stopnie doskonałości, trzeba być wyniszczonymi, pragnąć tego tylko ze względu na Boga. Jeżeli się zgadzamy na to, jakimi jesteśmy nie dlatego żeby paktować $\mathrm{z}$ wadami $\mathrm{i}$ ułomnościami, ale że to nasza naturalna bieda wtedy znajdujemy spokój. A martwienie się tym, niepokojenie żeśmy nie dość skupieni, nie dość umartwieni, wynika z miłości własnej. To zrozumienie, to przekonanie, że musimy ufać $w$ wyrównanie miłosierdziem Bożym naszych słabości jest początkiem życia wewnętrznego.

- Często sobie trzeba przypominać, że jesteśmy na służbie u Boga, w tym duchu kontrolować swe czyny i pytać: „Panie mój, czy jesteś ze mnie zadowolony?”

- W stosunku do ludzi myśl, że musi się dać rekompensatę za wyrządzoną przykrość, pobudza do większej czujności.

- Osią naszych modlitw i adoracji ma być odnawianie intencji: „Chcę wszystko dla Ciebie i z Tobą czynić". W pracy wewnętrznej opierać się trzeba na ufności, pamiętając, że Pan Jezus chce więcej duszy naszej, niż my sami. Dobrze, jeśli się czuje całą siłę egoizmu, ale nie miejmy pretensji pozbyć się go całkowicie, owszem lepiej, że on jest, że zostanie, bo wiemy, że to nie w naszej mocy go usunąć. 
Czynimy akty zewnętrzne przeciw niemu, ale sam korzeń zostawmy Bogu, bo On niemu jest głównym lekarzem. Na poprawę nigdy za późno.

- W duszy, która się długie lata opierała na sobie, zrozumienie i przekonanie, że wszystko zależy jedynie od łaski, musi być okupione długą walką i ciągłym niepowodzeniem. Tu nie można mierzyć latami. Gdy laska początkować zaczyna, trzeba iść za nią. To za mało wciąż przekonywać się o własnym niedołęstwie, trzeba jeszcze wierzyć, że nas Pan Jezus kocha, że pragnie naszej świętości i ją ziści. On Sam musi być jej twórcą naprawdę, a my nie możemy przeszkadzać. O chodzenie w obecności Bożej trzeba prosić. Techniczne stawanie w obecności Boga, o ile w duszy nie ma gruntu odpowiedniego, staje się niemożliwe nieraz, krępujące. Trzeba najpierw się do Pana Boga zbliżyć, pokochać, wtedy będzie się pragnęło tej obecności, a to pragnienie już będzie chodzeniem w obecności Bożej. Ale trzeba prosić, aby Pan Jezus sam to ziścił.

- Na wszystkie wewnętrzne trudności, pokusy, niepokoje, cierpienia jest jedno lekarstwo: oddanie się zupełne Panu Bogu: „Panie, jam Twoja”. Bóg dopuszcza różne ciosy, by oderwać od stworzeń, od pracy ukochanej, nieraz bardzo owocnej, by duszę doprowadzić do śmierci mistycznej. Trzeba się wciąż oddawać i prosić, by uzupełniał, naprawiał. To, że się nad tym cierpi - to nie jest złe, lecz oddawajmy się co dnia z ofiarą Chrystusa Eucharystycznego, z Jego Męką. To ma być wytyczne na dnie cierpień $\mathrm{i}$ bólu.

- Nie zawsze czujemy smak w krzyżu, ale wolą go nie odtrącajmy.

- Im głębszy akt, tym prostszy, tym mniej jest w nim co do powiedzenia. Dusza trwa przy Bogu i kocha.

- Pan Jezus $z$ drobiazgową zazdrością usuwa $z$ duszy umiłowanej i z życia wszystko, co przeszkadza do zjednoczenia $z$ Nim. Chce mieć taką duszę wyłącznie dla siebie. Jakże ją to powinno przejmować wdzięcznością i napawać otuchą. Pragnienie coraz większej ofiary mimo sprzeciwu natury i coraz głębszego wyniszczenia jest $\mathrm{z}$ łaski, ale czuwać trzeba, by tego nie czynić własną mocą. Prosić: „Ty $\mathrm{Pa}$ nie we mnie Sam się ofiaruj, niech Twoją siłą i Twoją miłością poświęcam się dla Ciebie. Niech to będzie Twoim dziełem".

- Dusza powinna starać się o dialog wewnętrzny z Chrystusem, ale nie zaniedbywać i strony moralnej na rachunku sumienia. Jednak zawsze się pytać: „Czy szłam za Twoim wołaniem, o Jezu?"

\section{ARCYBISKUP ${ }^{\mathrm{c}}$ TEODOROWICZ JAKO CZŁOWIEK}

Księdza Arcybiskupa Józefa Teodorowicza społeczeństwo znało przede wszystkim jako mówcę i pisarza ascetycznego, jako gorącego patriotę i społecznika. Mało osób miało szczęście obcować $\mathrm{z}$ nim w codziennym życiu i budować się wielkością jego charakteru. W jednej z niewydanych medytacji Ks. Arcybiskup pi-

"Maszynopis w objętości pięciu stronic formatu A 4. 
sze: „Tyś mnie powołał o Panie, jak ciągle z wiru świata prowadzisz ku wyraźnej Twej myśli. Otrzymałem osobną wokację dla Twego ducha. Mam jak Apostołowie: 1) być domownikiem Twoim, co z Tobą żyje i zespala się; 2) rozpatrywać się w Tobie przez medytacje Ewangelii Twojej na codzień; 3) opowiadać Ciebie, żywot Twej myśli o Tobie rozszerzać. Moje powołanie - to przedłużenie życia Twego we mnie wewnątrz; 4) wezwałeś mnie do życia, które miało odbić Cię na zewnątrz".

Arcybiskup został wierny tym zasadom, całe życie realizował ideał świętości, który sam skreślił w kazaniu na uroczystość bł. Jakuba Strepy ${ }^{119}$ we Lwowie 1910 roku ${ }^{120}$. Mówił na temat: „Kto to jest Święty?”, między innymi słyszymy: „Święci dzisiejsi zdaje się jakby ukryli swą świętość w codzienną szarą przędzę obowiązków i na oko niczym się nie różnią. Duch Święty szczególnie w naszych czasach, gdzie kult życia realnego tak jest wielki, ma upodobanie w Świętych, którzy z życia bieżącego nie opuszczą ani oczka i wchodzą w nie cali. Chrystus Pan jest twórcą tej świętości, a tak działa swą łaską, że świętość oddaje nam człowieka z jego wszystkimi skłonnościami i żądzami, które oczywiście łaska podniosła, uduchowiła. Charakter jednak jego, osobistość człowieka właśnie przez świętość się rozwinęły i podniosły. Wznosi się człowiek nad swoje skażenie, nad swoją słabość, nad siebie samego, a przez to nigdy nie jest bardziej sobą, aniżeli wtedy, gdy z łaską współdziała".

Wielkość ks. Arcybiskupa występowała przede wszystkim w stosunku do ludzi, odznacza się poszanowaniem osoby ludzkiej, choćby najgorszego człowieka. Dla biednych mial tkliwe współczujące serce nieraz nadużywane, w przyjaźni był wiernym, choćby wielki dystans dzielił jego, włodarza diecezji, z szarym człowiekiem. Dla matki był najczulszym synem i codziennie musiał znaleźć chwilę, by zagrać ze staruszką w karty. Nazywał ją ,panią dobrodziejką" i z pokorą przyjmował jej strofowanie za nałogową dystrakcję. Staruszka poczuwała się do obowiązku pilnowania, by jej dostojny syn idąc na jakieś ważne zebranie, czy przyjęcie nie zapomniał wziąć piuski, chusteczki, krzyża, czy orderu. Chorej matce sam nosił Komunię Świętą, a gdy wynoszono trumnę z jej zwłokami, płakał ukryty za framugą. Tak samo odcierpiał bardzo śmierć brata, z którym łączyła go wielka przyjaźń.

Przedziwnie delikatny był w stosunku do służby i umiał okazać wdzięczność za oddane świadczenia. Nieraz wśród bardzo intensywnej pracy przychodziła do niego gosposia ze swymi kłopotami gospodarskimi, a on z cierpliwością słuchał

${ }^{119}$ B1. Jakub Strepa-Strzemię (ok. 1340-1409), franciszkanin pracujący na Rusi, 1385-1399 gwardian klasztoru oo. Franciszkanów we Lwowie, 1391-1409 arcybiskup metropolita halicko-lwowski, w 1790 r. beatyfikowany. Do 1946 r. jego relikwie spoczywały w Bazylice Metropolitalnej ob. łac. we Lwowie, 1946-1991 w prokatedrze w Lubaczowie, od 1991 r. w skatbcu Katedry Wawelskiej w Krakowie.

${ }_{120}$ Błąd autorki; powinno być: 1909 r. Z inicjatywy abp. Józefa Bilczewskiego, w dniach 17-27 VI 1909 r. we Lwowie zorganizowano obchody 500 . rocznicy śmierci bł. Jakuba Strzemię. W uroczystościach uczestniczył m.in. abp Teodorowicz. I tak 19 czerwca t.r. w kościele oo. Franciszkanów wygłosił podczas nieszporów kazanie, 23 czerwca celebrował w katedrze łacińskiej sumę pontyfikalną, 26 czerwca podczas nieszporón kończących obchody rocznicy wygłosił kazanie. J. Bilczewski, Listy pasterskie, t. 2: Odezwy, ccinia i mony okolicznościowe, Lwów-Kraków 2005, s. 25-26. 
tego, choć mu to przerywało twórczą myśl. Podobnie odnosił się do licznych interesantów. Nieraz wiejska babina przyszła opowiadać mu o swojej chudobie, a on i pół godziny gotów słuchać, choć praca czekała, a sekretarka się niecierpliwiła, budując się równocześnie opanowaniem i dobrocią Arcypasterza. Nie umiał zrobić nikomu przykrości, a za wyrządzoną mimowolnie bezzwłocznie przepraszał. Z natury dowcipny i nawet cięty, czuwał, by tym nikogo nie zranić.

Kiedyś posądził pewną osobę o ambicję niezdrową wdarcia się na prezesurę Kongregacji Mariańskiej. Gdy się przekonał, że to była nieprawda, przeprosił ją, choć nikt o jego przypuszczeniu nie wiedział. Cieszył się, gdy mógł podkreślić dobre strony, zwłaszcza u tych, którzy byli mu przeciwni i wobec niego zawinili. Był prawdziwym pasterzem, dla którego żadna dusza nie jest obojętna.

W I liście pasterskim (1902) pisał: „O, gdybym wam, diecezjanie moi, miał rąbek duszy mojej uchylić, to $\mathrm{z}$ całą szczerością przyznałbym się wam, że ta właśnie apostolska praca w konfesjonale i na ambonie, osobisty kontakt szczególnie mnie pociaggał zawsze". Ta troska o dusze, o los i bezpieczeństwo Lwowian wystąpiła zwłaszcza w roku 1915-[191]6, gdy Austriacy wrócili do Lwowa i przeprowadzali bez śledztwa doraźne sądy na niewinnej ludności. Arcybiskup sam się narażał niejednokrotnie, by ratować ludzi od szubienicy.

Umiał po Chrystusowemu przebaczać. W znanej aferze w sejmie ustawodawczym, gdy chodziło o Śląsk, przebaczył tym, którzy zarzucili mu zdradę stanu, a gdy burza ucichła zażegnana przez partie prawicowe, powiedział $\mathrm{z}$ pokorą $\mathrm{w}$ gronie sióstr: „Pan Bóg dopuścił to za moje grzechy, nie mam do nich żalu”.

Gdy w sejmie rozgorzała polemika w sprawie reformy rolnej, znowu jeden z posłów znieważył Arcybiskupa. Dyktował mnie replikę, w której było dużo goryczy i ironii. Pasterz widząc grymas na mej twarzy, pyta: „Nie podoba się to siostrze?” A ja zuchwale odrzekłam: „Nie podoba, bo to nie pasuje do Ekscelencji”. [Wówczas odpark: - J.W.] „Proszę przyjść jutro na dalszy ciąg”. Nazajutrz podyktował odpowiedź pełną umiaru i powagi, część nocy spędził na modlitwie. Nie wziął mnie za złe zuchwalstwa, ale odnosił się z jeszcze większą dobrocią, dawał mi raz po raz swe piękne medytacje, z których powstał ostatni tom: „Z Jezusem Chrystusem" (Kraków 1947).

Arcybiskup żył Bogiem, żył z Jezusem Chrystusem, w Nim żył Jezus i dlatego obcowanie z Nim uszlachetniało i podnosiło do Boga nawet niewierzących. Oto, co pisze dr Elenberger ${ }^{121}$, który leczył już ciężko chorego Pasterza w sanatorium pod Wiedniem: „Nie przypuszczałem, że taką pustkę odczuję po wyjeździe ks. Arcybiskupa. Siadywaliśmy w bibliotece, mało mówili, a nigdy o religii (doktor był niewierzący). Jedynie czasem podnosiły się znad książki jego czarne głębokie oczy i padała jakaś uwaga, która wświdrowywała się w mój umysł i zapadała tam ołowiem, wagą swej mądrości. Jednego dnia Arcybiskup dostał ataku serca, stan był groźny. Był tak cudowny w obliczu grożącej mu śmierci, że na widok tego za-

${ }^{121}$ Osoba niezidentyfikowana. 
czynała dokonywać się we mnie przemiana. Ukląkłem, zacząłem się modlić, to było szczęście bijące od tej świetlanej postaci i wtedy objawiła mi się obecność Boga, uwierzyłem".

A co dopiero mają mówić dusze, które od niego czerpały światło w konfesjonale? Dać miejsce w duszy Chrystusowi, pozwolić, by on naprawiał nasze niedociągnięcia i błędy, oddawać $\mathrm{Mu}$ się bezustannie na ofiarę, nie mieć swoich programów, tylko śledzić wymagania Boga w duszy - oto była nić przewodnia jego dyrekcji. Umiał dojrzeć w każdej duszy wymagania Boże, nie zmuszał, nie łamał, zostawiał wszystko szlachetności duszy, ale powtarzał: „Lepiej umrzeć, niż odmówić Panu Jezusowi”. Był tak łaskawy, że zawsze służył duszy tą posługą Bożą. Nie odstraszało go ani zmęczenie, ani nawał zajęć, ani choroba, ani jego godność biskupia; był kapłanem, pasterzem szukającym zbłąkanej owieczki.

Źródłem tej jego wielkości był duch modlitwy. W jego notesiku znaleźliśmy porządek dzienny, w którym był zaznaczony czas na codzienną lekturę Listów św. Pawła i dzieł św. Teresy $z$ Avila, na godzinę adoracji, której skrupulatnie przestrzegał, jak to zaobserwowałam w Krynicy i Rabce. Postać jego wtedy tchnęła nadprzyrodzoną atmosferą, prawdziwie rozmawiał z Bogiem. O jego życiu modlitwy mówią medytacje,-które spisywał dla siebie, a które pod naszym naciskiem wydał drukiem. W tych perłach ascezy i mistyki - jak je nazwał ks. Żychliński ${ }^{122}$ - widać głębię przeżyć wewnętrznych i myśli nadprzyrodzonych. W zbiorku pt.: „Okruchy ewangeliczne” jest medytacja zatytułowana: „Dwie modlitwy”; tam czytamy: ,Jedna modlitwa bez słów, milcząca, cicha, nie potrzebuje ni głosu, ni krzyku, ale za to całe serce zeszło się $w$ akt wiary i cała przemówiła w niej dusza jak u niewiasty dotykającej szaty Jezusowej modlitwą, gdy usta milczą, a serce całe przemówi, gdzie to nie przymuszam Pana, nie myślę, czy On mnie shucha, tylko dotykam Go idącego mimo i już wiem, że mnie wysłuchał. Druga modlitwa Cyrenejki, to modlitwa unicestwienia. Siła jej i prężność nie idzie z poczucia siły praw, świętości, ale $z$ poczucia nicestwa. Te dwie modlitwy są wypróbowanej skuteczności. Są to strzały w serce Jezusa działające niechybnie. Znam, o Panie, ich celność, znam ich skuteczność. Tyś mnie nauczył Sam". I tak się w istocie modlił. Modlitwę doprowadził do stanu: gdy nie chce się osiągnąć żadnych rezultatów działalności, chce tylko jednego: kochać i milczeć, milczeć i kochać... (medytacja z roku 1937). Rok przed śmiercią mówił do mnie: ,Już mi tęskno na tej ziemi. Ileż to spokoju dla duszy w akcie oddania się Bogu bez względu na wszystko". Były to rzadkie chwile wynurzenia, zwykle pokrywał milczeniem tajemnice Królewskie.

122 Żychliński Aleksander Marian Józef (1889-1945), święcenia kapłańskie w 1913 r. w Poznaniu, 1913-1917 studia specjalistyczne uwieńczone doktoratem teologii, 1917-1918 wikariusz par. Gostyń Wlkp., 1918-1939 wykładowca teologii dogmatycznej w Seminarium Duchownym w Poznaniu, 1927-1929 rektor Seminarium Duchownego w Gnieźnie, 1939-1945 przebywał w Pleckiej Dąbrowie, Kalinie Wielkiej k. Miechowa i w Seminarium Duchownym w Kielcach. Zmarł 21 XII 1945 r. w Gnieżnie. Był autorem rozpraw filozoficznych i teologicznych w duchu tomistycznym. M. Banaszak, Żychliński Aleksander Marian Józef, [w:] SPTK, t. 7, s. 519-523. 
Duch modlitwy uwydatnił się w czasie ostatniej choroby, ustawicznie skupiony powtarzał: „Będzie to, co Pan Jezus chce”. Prawdziwie mógł ze św. Pawłem powtarzać: „Mnie życiem jest Chrystus”. Jezusa ukochał nade wszystko, dla Niego żył, Jemu poświęcił dzieło swego życia. Chciał stworzyć wielki dokument boskości Chrystusa w odpowiedzi na dzieło Renana i od 1906 zbierał materiały. Jezusa głosił w kazaniach, Jemu uczył służyć młodzież, która się do niego garnęła oraz Polki ziemi kresowej, które związał w kongregację pod wezwaniem Matki Boski Kochawińskiej i sam był moderatorem do śmierci, pragnął przez niewiasty odrodzić społeczeństwo. W obronie spraw Jezusa w duszach zajął się słynną stygmatyczką z Konnersreutch Teresą Neuman[n], ogłosił o niej obszerną pracę: „Zjawiska mistyczne" (Poznań 1933) ${ }^{123}$ i dwie niemieckie ${ }^{124}$. Sam był kilkakrotnie w Kennersreuth, był świadkiem krwawej ekstazy Teresy i z przejęciem opowiadał wiele szczegółów w rozmownicy SS. Zmartwychwstanek. Ks. Biskup Lisowski towarzyszący mu zdradził, że Teresa powiedziała, że Arcybiskup jest miły Panu Bogu, przepowiedziała też ciężkie czasy, jakie Polskę czekają.

Arcybiskup wiele przecierpiał, stając $\mathrm{w}$ obronie nadprzyrodzoności podobnych zjawisk, dowodził z przekonaniem, że nie można tylko ze szkiełkiem i skalpelem lekarza podchodzić do tego, w czym może być działanie Ducha Świętego. Sam był przekonany, że te zjawiska są protestem nieba na panoszący się $\mathrm{w}$ religii racjonalizm.

Nie byłaby zupełna sylwetka Arcybiskupa, gdyby nie wspomniało się o jego wyjątkowej miłości Polski. We wspomnianym wyżej liście pasterskim pisał: „Kocham społeczeństwo polskie, kocham jak kapłan i obywatel, i te dwie miłości się sprzęgają i dopełniają nawzajem. Kocham te społeczeństwo, jak się kocha przyjaciela, którego się bierze jakim jest, $\mathrm{z}$ jego niedoskonałościami i ułomnościami. Kocham je więc tak, jak się kocha Ojczyznę".

O prawa Polski walczył w Wiedeńskiej Izbie Panów, reasumując swe wywody w słynnej mowie 1917 roku. Ale przede wszystkim walczył o Królestwo Boże w Polsce, co tak jasno uwypuklone jest w zbiorowym wydaniu kazań: „Na przełomie". Był wychowawcą narodu, jego wodzem ideowym. Nie wahał się mówić twardej prawdy, ale karcąc równocześnie wskazywał drogę ku odrodzeniu, uczył pracy i ufności. Ks. Wądołowski ${ }^{125}$ w nekrologu tak o tym napisał: „Cała Polska była jego diecezją, wszechdzielnicowość znamieniem jego pracy. Podejmuje rolę łącznika rozdartego na trzy części narodu, ale odpowiedzialną wobec historii. W Poznańskiem staje w obronie pacierza w języku ojczystym, jeździ do Berlina, w Królestwie miewa kazania, rekolekcje, odczyty itd. Tajemnica jego wpływu w tej płaszczyźnie narodowej thumaczy się tym, że umiał trafiać do serca narodu, że odpowiadał najgłębszym pragnieniom jego duszy, że oddał najwierniej rytm

\footnotetext{
${ }^{123}$ Por- przypis 78 niniejszej edycji.

${ }^{124}$ Por. przypis 100 niniejszej edycji. Druga publikacja niezidentyfikowana.

${ }^{125}$ Osoba niezidentyfikowana.
} 
przeżywanej chwili dziejowej, że splótł w niej przeszłość z nadziejami na przyszłość".

W roku $1906^{126}$ przez pewne nieporozumienie wyszło pismo Stolicy Świętej, które nie było słuszne wobec sprawy naszego narodu ${ }^{127}$. Cóż wówczas czyni śp. ks. Arcybiskup? Spieszy do Rzymu natychmiast by uprosić św. Piusa $X^{128}$ o zmianę w tymże piśmie. Otrzymuje ją, ale zarazem zyskuje pochlebne uznanie Papieża ${ }^{129}$.

Toteż cała Polska brała udział w jego złotym jubileuszu 1937 roku, a on upokorzony hołdami wyznał: „Jeżeli podnietą w pracy było mi środowisko kothujące prądów i życia na ziemi, to nie mniej busolą moją i sterem było środowisko nadziemskie, z którego padały promienie tych idei, jakie kierowały ruchami narodowymi. Jam był tylko nieudolnym tłumaczem tych znaków, jakie w wielkich przełomowych chwilach wypisuje Bóg w dziejach na niebiesiech. Te znaki podobne są świetlanym literom wypisanym na banknotach. Na oko są niewidoczne, ale jednak odczyta się je, gdy się banknot podniesie ku górze, ku świathu. Ilekroć patrzyłem na skłębione dzieje i problemy na ziemi, tylekroć razy podnosiłam je ku górze, ażeby na mlecznych drogach Bożych rozpatrywać łączność ich z drogami ziemskimi i skoro dotarłem raz do odszyfrowania idei w jej szacie podwójnej, ziemskiej i nadziemskiej, wtedy chwwytałem się jej oburącz, nie oglądając się już więcej na nic i na nikogo. Mogę powiedzieć, że na takiej drodze nie ma miejsca dla jakichkolwiek osobistych korzyści i względów, ale to jest prostym następstwem służby idei. Jeżeli $\mathrm{w}$ jakiejś odrobinie wchodzi tu w grę moja zasługa, to w tej nie uczestniczyłem sam, lecz lwia część należy do Tego, który mnie oświecał i umacniał, we mnie i przez mnie działał, Chrystusa Jezusa" ${ }^{30}$.

Nad trumną zmarłego Pasterza w grudniu 1938 roku Metropolita Sapieha, przemawiając imieniem Episkopatu powiedział: „Ten, którego tak umiłował, o którym z takim zapałem pisał, powołał go do wiecznej chwały, powołał, aby patrzył

${ }^{126}$ Błąd autorki; powinno być: $1905 \mathrm{r}$.

${ }^{127}$ Dnia 3 XII 1905 r. Pius X ogłosił brewe Poloniae populus, w którym wzywał biskupów Królestwa Polskiego do wysiłków nad przywróceniem ładu, pokoju i jedności zakłóconych wystąpieniami ,radykałów narodowych" w nurcie wrzenia rewolucyjnego w imperium carskim. Apelował o przestrzeganie nakazów Kościoła oraz zasad sprawiedliwości i miłości bliźniego, ale zdecydowanie potępiał strajki, opowiadając się za erygowaniem instytucji podnoszących stopę życiową robotników. Zdaniem historyka Kościoła, „były to zalecenia świadczące o nieznajomości sytuacji w cesarstwie i w Królestwie Polskim". Z. Zieliński, Papiestwo i papieże dwóch ostatnich wieków, t. 2, Poznań 1986, s. 22-23.

${ }_{128}$ Pius X (1835-1914), święcenia kapłańskie w 1858 r., 1875-1884 kanclerz Kurii Biskupiej w Treviso oraz ojciec duchowny w Seminarium Duchownym, 1884-1893 biskup diecezjalny Mantui, 1893-1903 patriarcha Wenecji i kardynał, 1903-1914 papież, w 1951 r. błogosławiony, w 1954 r. święty. R. Aubert, Pius $X$, [w:] LThK, 8 Bd., hrsgb. von J. Höfer, K. Rahner, Freiburg im Breisgau 1986, kol. 538-540.

${ }_{129}$ Charakterystyczna jest $w$ tym kontekście uwaga abp. Józefa Bilczewskiego, nie pozbawiona zapewne subiektywizmu, zanotowana w jego dzienniku: „Opinia ludzi najpoważniejszych: Ks. arcyb[iskup] Teodorowicz nie zawahał się skompromitować papieża przez wydostanie komentarza, byle siebie podnieśc". AZSK, J. Bilczewski, Dziennik, s. 31.

${ }_{130}$ 50-lecie kaplaństwa J[ego] E[kscelencji] Ks. Arcybiskupa Józefa Teodorowicza. Przemówienie J[ego] E[kscelencji] Ks. Arcybiskupa, „Gregoriana", 1937, z. 3-4, s. 96-97. 
na Boga twarzą w twarz i dlatego z ufnością możemy powtórzyć tak serdeczne wezwanie katakumb: «Vivas in Christo»"13!.

\section{WSPOMNIENIE ${ }^{d}$ O Ś.P. ARCYBISKUPIE JÓZEFIE TEODOROWICZU}

\section{a) Arcybiskup w Warszawie podczas Rady Regencyjnej i w latach póżniejszych}

Po strasznej wojnie, choć jeszcze niezupełnie wolna, Warszawa odetchnęła. Życie tętniło w stolicy - zjeżdżano się do niej thumnie. Odbywały się narady nieomal we wszystkich dziedzinach życia: religijnego, politycznego, gospodarczego itd. Organizowano, robiono projekty na przyszłość. Życie religijne ożywiło się też. Urządzano konferencje, rekolekcje, gdy rozeszła się wieść, że Arcybiskup Teodorowicz przyjechał wezwany na narady i że będzie przemawiał trzy razy w kościele Karmelitów. Będą to konferencje dla inteligencji. Zawrzało w mieście, dobijano się o bilety wstępu, a trudno było o nie, bo kościół jest niewielki, a tyle ludzi chciało słyszeć wielkiego mówcę. Zaciekawienie było też niemałe: „O czym będzie mówił? Czy będą zwröty polityczne? Czasy są tak ważne, przełomowe”. Niektórzy są wprost zaniepokojeni, jakoby Ekscelencja mówi bardzo śmiało...

Godzinę przed rozpoczęciem konferencji kościół przepełniony. A przed kościołem thum, morze głów, ledwo można się przedostać. Daremnie księża ostrzegają, że nie warto czekać, bo miejsc nie ma. Wreszcie nadjeżdża auto Arcybiskupa. Wjeżdża w thum i staje, nie mogąc się posunąć dalej. Jeden $z$ księży wychyla się $\mathrm{z}$ auta i prosi, by się usunięto. Arcybiskup uśmiechnięty patrzy na cisnącą się ciżbę, w której wszystkie warstwy społeczne są przedstawione. Wreszcie rozlegają się wołania i kilka osób zbliża się do samochodu prosząc, aby Arcybiskup przemawiał na placu do wszystkich. Thumaczą im, że to jest niemożebne z powodu stanu zdrowia Ekscelencji. Lecz on nagle wstaje i wita „kochanych warszawian”, żałując, że nie może dłużej tutaj mówić, dodaje kilka zdań o Polsce i Warszawie Chrystusowej, po czym auto rusza przez utworzony szpaler do seminarium.

W kościele cisza-wyczekiwanie. Przed ołtarzem olbrzymi klęcznik tonie w fioletach. Wreszcie boczne drzwi otwierają się i poprzedzony przez duchowieństwo i kleryków wchodzi Arcybiskup. Na tle białych filarów zarysowuje się Jego wspaniała postać, prawdziwy „książę Kościoła”. Klęka i pogrąża się w kornej modlitwie, cała Jego postawa mówi o poddaniu i czci, po czym wchodzi na ambonę. Dziwny spokój i skupienie promieniują od Niego. Zaczyna od powitania Warszawy, której elita intelektualna skupia się tutaj. Czuć w kościele naprężenie: co On powie? Ale Arcypasterz nie przybył, by mówić o polityce, ani nawet o chwili obecnej, nie, On przyszedł by mówić o Polsce, o jej misji dziejowej, o jej stosunku do

${ }^{131}$ Lac.: żyj w Chrystusie.

${ }^{\mathrm{d}}$ Maszynopis w objętości 8,5 stronic forman A 4. 
Chrystusa i Kościoła. Rozbrzmiewa donośny głos przypominający prawa Boże i Miłość Bożą, mówiący o obowiązkach narodu i jednostek. Padają nieraz twarde słowa wypominające winy, ostrzegające przed ich konsekwencjami. Nawołuje do odrodzenia się w Chrystusie, do szerzenia Królestwa Bożego w narodzie i w duszach. Wreszcie milknie potężny Jego głos, Arcybiskup schodzi z ambony poprzedzony alumnami i idzie przed wielki ołtarz, lecz nie klęka już na wspaniałym klęczniku, lecz na ziemi i pochyla się głęboko, wszyscy klękają. Teraz uczy on przykładem - pokorny sługa klęczący przed Panem swoim!

Wychodzono z kościoła w milczeniu, nie było rozmów, zachwytów, ocen, czuć było, że ludzie przeżywają to, co usłyszeli. Czasem tylko słychać było półgłosem wymówione słowo, które streszczało tak wiele: „Skarga drugi”. Trzy dni powtarzało się to samo. Thumy skupione słuchały Słowa Bożego, a Arcybiskup porywał dusze, wznosił je ku Bogu i przygotowywał do shuzby Bożej. Ale na tym nie zakończyła się Jego praca apostolska. Dawał rekolekcje dla różnych grup: pań z inteligencji, nauczycielstwa, starszej młodzieży itd. itd. Zaciszne klasztorne kaplice nie mogły pomieścić wszystkich, ale ci, co skorzystali z tych ćwiczeń duchowych odchodzili pokrzepieni z jedną dyrektywą: trzeba iść do Chrystusa, bo tylko z Nim i przez Niego odrodzimy siebie i kraj.

Wprowadzał w czyn to, co kiedyś pisał: „Ukształtować, urobić w was Chrystusa Jezusa, wyryć Go w waszych duszach i sercach, ożywić was Jego duchem, urobić was na podobieństwo Jego, a nie spocząć, dopóki jedno z Nim się nie staniecie przez zjednoczenie $z \mathrm{Nim}$ - oto nasze zadanie".

Wkrótce jednak zmieniła się praca Arcybiskupa, gdyż został On obrany posłem na Sejm ${ }^{132}$. Praca polityczna pochłaniała Jego czas, a oczywiście zmieniło się też ustosunkowanie wielu do Niego. Choć był zawsze otoczony szacunkiem $i$ uznaniem najliczniejszych sfer społecznych, jednak miał też dużo przeciwników, a nawet i wrogów. Nic dziwnego: przedstawiał On przecież Kościół. Jego spraw bronił i pilnował, a w tej dziedzinie wre zawsze walka! Gdy się Go widziało na terenie sejmowym w tym tak różnorodnym otoczeniu, uderzało Jego zachowanie: był zawsze bardzo prosty, dostępny, ale jakaż godność biła od Jego postaci. Nie zapomnial nigdy kogo przedstawiał, nawet podczas tak męczących całodziennych posiedzeń, po debatach tak wyczerpujących nie pozwalał sobie na jakieś „laiserr aller"133, był zawsze correct ${ }^{134}$ i godny Książę Kościoła i Polak wysoko dzierżący swój sztandar.

\section{b) Migawki z życia sejmowego}

Duży korytarz sejmowy, jasno oświetlony. W głębi otwierają się drzwi i cały zastęp posłów wychodzi z sali. Na czele idzie dwóch posłów dyskutując tak żywo,

\footnotetext{
${ }^{132}$ Por. przypis 1 niniejszej edycji.

${ }^{133}$ Fr.: pozostawienie spraw ich własnemu biegowi.

${ }^{134}$ Fr.: poprawny, właściwy, przyzwoity.
} 
że nic wokoło siebie nie widzą. Przed hallem stają otoczeni kolegami. Rozmowa ich przybiera wkrótce ton ostrej kłótni i wywabia z sąsiedniej poczekalni różnych interesantów. Staję z boku i patrzę, co z tego wyniknie? Wtem drzwi od wejścia otwierają się i na progu staje wysoka postać w czerni: Arcybiskup Teodorowicz. Chwilę zatrzymuje się, odpowiadając na liczne ukłony i powitania, potem idzie na korytarz. Oczywiście słyszy co tam się dzieje, półuśmieszek ironiczny błąka się na Jego wyrazistych ustach, a oczy trochę przymrużone bacznie patrzą przed siebie, a tam o dwa kroki kotłuje się po prostu. Powoli dochodzi On do tego kłębowiska i przystaje bez słowa, lecz niektóre osoby poznają Go i usuwają się na bok, tylko dwóch przeciwników politycznych chwytając się za marynarki w dalszym ciągu kłóci się. Arcybiskup jest tuż koło nich, góruje nad nimi swą wyniosłą postacią i nagle odzywa się najbardziej wersalskim tonem: „Witam Panów... może Panowie przepuszczą?" Słowa te wywierają wpływ piorunujący, obaj rozkrzyczani posłowie odskakują od siebie, przejście wolne, Arcybiskup majestatycznym, powolnym krokiem wkracza $w$ ten szpaler roznamiętnionych polityków i przechodzi, wygląda bardzo ubawiony.

Sala sejmowa, dzień wielkiej debaty-plenum, na prawicy na bocznym fotelu siedzi Arcybiskup.Śledzi przemówienia z natężoną uwagą, czasem coś notuje. Doskonale można śledzić na Jego twarzy niektóre wrażenia. Gdy mowa porusza wielkie zagadnienia polityki ogólnej lub zagranicznej, zagadnienia ustawodawcze - zainteresowanie Arcybiskupa jest bardzo widoczne, gdy przechodzi na drobne sprawy, gdy są dyskusje ,à la tempète dans un verre d'eau"135 jest widocznie znudzony, czasem znużony. Nic dziwnego, to był umysł, który obejmował szerokie kręgi zagadnień politycznych, obliczał i ważył wszelkie ich konsekwencje, trudniej Mu było naginać się do drobniejszych spraw. Wyrobiony parlamentarzysta orientował się szybko, miał wybitny ,don de replique"136, humor wrodzony i był bardzo dowcipny. Gdy jeden z bardzo początkujących parlamentarzystów przyczepił się do jakiegoś szczegółu historycznego podanego przez Arcybiskupa, ten $z$ wielką kurtuazją i subtelną ironią prosił o te nowe źródła historyczne z których „Pan Poseł" czerpał swe wiadomości, co danego posła zbijało $\mathrm{z}$ tropu, że swą interpelację ukończył piorunem... nie posiadając oczywiście żadnych źródeł. Raz po posiedzeniu sejmowym zebrało się u Arcybiskupa kilku posłów. Mówiono o Jego przemówieniu, które wywołało wrzawę, o Jego roli w sejmie. Siedział zamyślony przy biurku, wreszcie rzekt: „Czy ja wiem, czy ja coś dobrego robię w tym sejmie, polityka ta takie bagno" i wyciągając z szuflady gruby rękopis z tytułem „Życie Chrystusa” dodał: „Często myślę, że trzeba sejm porzucić, a poświęcić się tylko tej pracy, bo właściwie dla kapłana najważniejsze pracować dla Chrystusa dusz". Zwrócono Mu uwagę, że i w sejmie pracuje On dla Kościoła. „No, tak, wiem, żeby

\footnotetext{
${ }^{135}$ Fr.: jak burza w szklance wody.

${ }^{136}$ Fr.: zdolność repliki.
} 
nie to, że to walka o prawa Kościoła to bym już odszedł, ale niech Pan Bóg wszystkim kieruje".

\section{c) Apostolstwo Ks. Arcybiskupa}

Apostolstwo Arcybiskupa było rozległe i różnorodne! Nie tylko słowem, tj. kazaniami i konferencjami szerzył Królestwo Boże, nie tylko pisał wiele, ale też $i$ indywidualnie pomagał duszom przez spowiedź, rozmowy, listy. Ile osób podźwignął, ile wyprowadził na dobrą drogę, ile prowadził ku szczytom zjednoczenia. Bóg jeden wie. Siłą rzeczy ta dziedzina Jego pracy jest najmniej znana. Nie zacieśniał się On do pewnej sfery lub poziomu, nie, był dostępny, chętny w niesieniu pomocy duchownej, a Jego wiedza psychologiczna, bardzo subtelna intuicja i dobroć dopomagały Mu w zdobywaniu dusz, a duszom ułatwiało kontakt z Nim. Jednak może największą siłą w duszpasterstwie była Jego bezosobowość. Uważał się naprawdę tylko za „narzędzie Boże”. Pragnął jednego: poznać zamiary Boże względem danej duszy i dopomóc do wypełnienia woli Bożej całkowicie. Miał głębokie poczucie odpowiedzialności względem dusz, które się do Niego zwracały, dlatego też rzadko podejmował się całkowitego kierownictwa. Był niesłychanie subtelny i dobry, bardzo dyskretny. Umiał czekać na wyznania, umiał zachęcić do nich przez mądrze stawiane pytania. Trudno, a raczej niemożliwe jest pisać o tej dziedzinie pracy Arcypasterza, ale kilka szkiców i opisów rzuci jednak trochę światła na Jego ustosunkowanie do dusz.

Zjazd nauczycielski (r[ok] 1936 czy [19]37?). Z daleka nieraz przybyli delegaci, najwięcej $z$ kresowych szkół. Jedno przemówienie wygłasza Arcybiskup. Głęboko i serdecznie przemawia, widać, że chciałby pomóc, podźwignąć, rozjaśnić światłem Bożym te najczęściej tak szare i pracowite życia. Pomiędzy słuchaczami, nieznana nikomu prawie, młoda nauczycielka z zapadłej mieściny kresowej przyjechała w zastępstwie chorej kierowniczki, chłonie wszystko co słyszy, to tak ważne wydarzenie w jej życiu, ten zjazd. Ma też polecenia do spełnienia zagadnień $\mathrm{i}$ trudności nie brak u nich. Radzi się tu i ówdzie, była nawet w prezydium, ale nikt jej w niczym nie dopomógł. Wreszcie ktoś radzi: „Najlepiej pójść z tym do Arcybiskupa Teodorowicza, to przecież sprawa religijna". Co takiego? Ona ma iść do tego dygnitarza tak imponującego, ależ to niemożebne! Lecz już się ktoś zakrzątnął, uprosił audiencję i wysyłają ją do pałacu. Jest bliska płaczu $z$ onieśmielenia $i$ sama nie wie co ma powiedzieć, o co prosić. „Lecz wszystko inaczej się ułożyło niż myślałam - opowiada potem - na progu dużego salonu powitał mnie dobrotliwie Arcybiskup. Ani się nie opatrzyłam, jak już siedziałam koło Niego. Zachęcał i pomagał mi pytaniami do mówienia, orientowal się bardzo szybko i po krótkiej rozmowie wszystkie nasze zagadnienia zostały rozwiązane, o ile to było moźebne, dyrektywy jasno dane. Uderzył mnie Jego sposób ujmowania sprawy, bardzo szeroki, a jednak liczący się z nawet drobnymi szczegółami życia. Nie koniec na tym, zainteresował się moją osobą, moim życiem, duszą z taką dobrocią i życzliwością, 
że wszelkie onieśmielenie znikło i mówiłam tak otwarcie jak z ojcem. Ileż On mi wtedy dał! Wychodząc, nie wiedziałam już jak dziękować i przepraszać, że tyle $\mathrm{Mu}$ czasu zajęłam, przerwał zaraz: «Ależ nie, to mój obowiązek pomagać» rzekł kreśląc nad moją głową znak Krzyża św. Z sercem przepełnionym wdzięcznością odchodziłam. Poszłam do Arcybiskupa - znalazłam ojca".

Książki i artykuły Arcybiskupa Teodorowicza, wywoływały nieraz wymianę korespondencji z czytelnikami, najczęściej zupełnie nieznanymi. Raz napisał do Niego młody ksiądz z kresów. Pisma Arcybiskupa zrobily na nim wielkie wrażenie, otworzyły przed nim nieznane prawie horyzonty. Arcybiskup był widocznie przejęty tym listem i mówił, że już kilka razy otrzymywał takie listy, które są Mu troską, gdyż widzi jak bardzo młodzi księża potrzebowaliby podtrzymania, żyjąc często w bardzo ciężkich warunkach i bardzo osamotnieni. Odpisał zaraz. Po jakimś czasie ów kapłan przyjechał do Lwowa i prosił o audiencję, został natychmiast przyjęty, lecz nie tylko na krótką audiencję, ale został zatrzymany na parę dni w pałacu, a Arcybiskup niemal cały swój czas mu poświęcał. Wyjeżdżając, nie wiedział jak wyrazić swą wdzięczność i rzekł do otaczających go: „To jest prawdziwie Pasterz i Ojciec. To jest święty".

\section{d) Garstka wspomnień z ostatnich lat Arcybiskupa}

Ostatnie lata swego życia przebył Arcybiskup w ciszy i osamotnieniu. Zdrowie Jego nie pozwalało Mu na podróże i udzielanie się, wzrastająca głuchota utrudniała wiele. Miał kilka osób z rodziny, z którymi był w ścisłym kontakcie, do których jeździł na wieś, miał przyjaciół i we Lwowie i w całej Polsce. Odwiedzano Go więc czasem, ale na ogół był sam i oddał się zupełnie piśmiennictwu i sprawom swej diecezji. Kilka klasztorów zaszczycał Arcypasterz specjalnym uznaniem i przyjaźnią, i odwiedzal je, wygłaszając czasem dla zakonnic prześliczne konferencje o życiu wewnętrznym o Panu Jezusie. $Z$ osobami, z którymi żył bliżej, był Arcybiskup bardzo prosty, szczery, serdeczny. Mówił o swoim życiu, o przeszłości, mówił o swych pracach pisarskich, mówił nawet o swej duszy i z podziwem można było śledzić cudowne Boże przemiany w niej. U schyłku życia o tak bogatym i różnorodnym plonie, coraz bardziej pogrążał się w pokorze i unicestwieniu (o czym zresztą świadczą jego rozmyślania $z$ ostatnich lat). Coraz bardziej Pan Jezus był Mu wszystkim, coraz bardziej sądził i oceniał wszystko z punktu widzenia Bożego, z punktu widzenia wieczności.

Nieraz powtarzał, że czyni swe obrachunki życiowe, że żahuje lat spędzonych w pracy politycznej, choć wtedy niejedno zdziałał dla Polski i Kościoła. Oceniał swą pracę surowo i twierdził, że jednak lepiej, gdy kapłan pozostaje na niwie duszpasterskiej, pracując tylko dla Kościoła i dusz, niż idąc na arenę polityczną. „Polityka - mawiał - to praca, która prawie zawsze obniża poziom duchowy każdego".

Do końca życia usilnie pracował nad „Życiem Chrystusa”, olbrzymim dziełem, które niestety nie dokończył. Raz przerwał to pisanie, aby zająć się sprawą Te- 
resy Neuman[n], o której napisał znaną książkę, a i to sobie wymawiał, twierdząc, że to $\mathrm{Mu}$ zajęło dużo czasu i oderwało od dalszego układania „Życia Chrystusa”; zdawało się, że ma przeczucie, że je nie dokończy. W roku 1934 tak pisze do jednej zaufanej osoby ${ }^{137}$, z którą lubił dzielić się swymi troskami pisarskimi: „Piszę bardzo intensywnie "Ż̇ycie Pana Jezusa», które mi teraz jakoby samo się zlewa", a w innym liście: „Gonię formalnie za żywotem Pana Jezusa, więc proszę o modlitwę”. Dużo czasu zabierała $\mathrm{Mu}$ ta korespondencja, coraz bardziej obszerna, o czym świadczy list pisany w czerwcu 1936 r., gdy był na kuracji: „Dziękuję za pytanie o mnie. Tylko nie wolno mnie się pytać nad czym ja pracuję, bo przecież ja wypoczywam, a nie pracuję. Lekarz pozwolił mi tylko czytać kryminalne romanse (sic!). Co innego gdyby M.[atka] pytała, jaka jest moja «nebenbeschäftigung» ${ }^{138}$, a to co innego. Jest nim przede wszystkim pisanie listów za granicę, do różnych stron: Rzym, Szwajcaria, Belgia, itd. z powodu mej książki, która jak widzę dużo narobila wrzawy. Chcę nawet Konnersreuth thumaczyć na angielski. Powoli zaczynam zaglądać do «Życia Chrystusowego»".

W r[oku] 1935 zapadł Arcybiskup tak na zdrowiu, że nie było prawie nadziei na wyzdrowienie. Tragicznie smutny był wówczas Jego widok. Mówił z trudnością, zmieniony był do niepoznania. Chwilami zdawało się, że przytomność traci, potem znowu zupełnie jasno zdawał sobie sprawę ze swego stanu i poddawał się woli Bożej bez zastrzeżeń. Gdy raz powiedziałam $\mathrm{Mu}$, że się tak gorąco modlimy o zdrowie dla Niego, przerwał mi mówiąc: „Nie proście o zdrowie, ale o to, aby się wola Boża spełniła” - „Ale my możemy prosić o zdrowie dla Ekscelencji” - odrzekłam. Zawahał się chwilkę, potem dodał: „No tak, wy możecie, ale ja mogę tylko prosić o wypełnienie woli Bożej".

Wywieziono Go na wieś i naprawdę nie wiadomo jak to się stało, pomimo całego pesymizmu lekarzy, wbrew wszelkim oczekiwaniom Arcybiskupowi nie tylko się polepszyło, ale przyszedł zupełnie do zdrowia i jeszcze kilka lat pracował usilnie. Podczas rekonwalescencji napisał do przyjaciół list $\mathbf{z}$ którego podajemy następujący urywek: „Zakrojone było wszystko już na śmierć, ale nie na polepszenie. Pewno modlitwy wasze mnie dźwignęły, ulepszyło mi się i to niespodziewanie. Bóg chce, bym się zżył ze śmiercią jeszcze na ziemi, bym się uczył dziękować za nią, oddawać Bogu ją w warunkach przez Niego określonych, jednym słowem bym pod pewnym względem uczył się jej pragnąć i ją kochać. Jakże mi do tego daleko... i dlatego jestem natrętnym żebrakiem, który wciąż na nowo prosi o modlitwy, o to, czego mnie dostaje".

Raz w r[oku] 1936 czy [19]37 przybył do klasztoru, z którym łączyły Go serdecznie stosunki. Przyjechał, bo chciał przeczytać kilka fragmentów „Żywota Chrystusa", jeszcze nie wydanych, kilku osobom. Niezapomniane są to chwile. wstanka.

${ }^{137}$ Była nią zapewne autorka niniejszych wspomnień, s. Barbara Żulińska CR lub inna Zmartwych-

${ }^{138}$ Niem.: zajęcie uboczne. 
Siedział na niskim fotelu przy lampie, która jasno oświetlała jego wyraziste rysy, przed Nim stał stół założony papierami. Czytał uważnie, głośno, dobitnie, czasem zatrzymywał się zamyślony, czasem coś poprawiał. Poprosiliśmy usilnie, aby jak najprędzej wysłał gotowe rozdziały do wydawcy, obawiając się, że jak zacznie poprawiać ten rękopis to znowu odłoży się wydanie, jak to już tyle razy było! Śmiał się, przyznając się do tego i odpowiadał, że jego przyjaciele warszawiacy ,prawie że mi wykradli «Z Betlejem do Nazaretu», aby przyspieszyć wydanie". Przyznawał, że zanadto poprawia, ale potem dodawał poważnie: „Bo gdy się pisze o Panu Jezusie, jak się przemyśla Jego czyny, Jego słowa, to człowiek dobrze pojmuje, jak wszystko co się o Nim mówi i pisze jest blade i nie wystarczające, a gdy się jeszcze omodli i przemedytuje, to tyle myśli i świateł przychodzi, że chciałoby się ciągle coś uzupełnić, coś ulepszyć”... i tak było rzeczywiście. On ten „Żywot Chrystusa" szlifował jak artysta kamień bezcenny, ale też czerpiąc w rozmyślaniu i coraz większym zjednoczeniu z Chrystusem światła przeogromne, chciał je przelać na te karty, by dusze więcej skorzystały i lepiej Jezusa poznały.

Po przeczytaniu nam różnych fragmentów, zaczął Arcybiskup mówić o Chrystusie, był to naprawdę poryw duszy płonącej miłością ku Jezusowi. Jak On pragnął przyczynić się do tego, ,aby Go trochę lepiej poznano” - „Dhugo wahałem się przed rozpoczęciem tej pracy” - mówił. „Tyle już pisano życiorysów Chrystusa $i$ tak pięknych, potem zrozumiałem, że pisać trzeba, bo ciągle ludzie, zapatrywania i potrzeby zmieniają się, więc trzeba dawać coraz to inne ujęcia, poddawać inne myśli. Przy tym życie Chrystusa, to przecież skarbnica nigdy nie wyczerpana, więc zacząłem pisać dla obecnych pokoleń”. Z jakim bólem mówił o „indyferentyzmie” dusz, pomijając już wrogów Chrystusowych. I ten starzec wówczas już tak chory, gdy mówił o swym Panu ukochanym, miał taką moc, taką siłę, jaką się czerpie tylko w miłości.

Niejednokrotnie w poufnych rozmowach $\mathrm{z}$ Nim padały słowa, które uchyliły rąbek Jego życia wewnętrznego, życia tak zjednoczonego z Jezusem. Przy spowiedzi lub rozmowach duchownych czasem wprost odczuwalne było, ,że nie ja żyję, ale Chrystus we mnie"; potwierdzenie tego daje nam tak jasny urywek z Jego X medytacji.

Jak On pragnął, by coraz więcej dusz oddawało się Jezusowi... „na całego”, jak mówił, jak On nie mógł ścierpieć połowiczności w oddawaniu się, jak strzegł praw Jezusowych przy kierownictwie duszą... może potwierdzić Jego powiedzenie do jednej osoby, której duszą do końca życia się zajmował. Wobec trudności nie do pokonania, chciała ona szukać innej drogi; gdy o tym się dowiedział rzekł stanowczo: „Lepiej umrzeć, niż sprzeniewierzyć się woli Jezusowej”.

Św. Paweł był Jego mistrzem w duszpasterstwie. Ciągle go cytował, zachęcał też do rozmyślań nad Epistołami.

Konsekwentnie i wytrwale dążył do wykorzenienia z duszy wszystkiego, co by mogło się sprzeciwiać zjednoczeniu z Jezusem. Jako wytrawny psycholog umiał się doszukać najsubtelniejszych objawów egocentryzmu, miłości własnej i wytykał 
je niemiłosiernie. Był cierpliwy, umiał czekać, ale był też bardzo wymagający. Jego ulubionym i bezapelacyjnym argumentem było powiedzenie: „Przecież Jezus tego chce, to dla Jezusa"... wypowiedziane takim tonem, z takim serdecznym naciskiem, że wprost niemożebne było się oprzeć, tak się odczuwało, że On rzeczywiście w imieniu Jezusa prosi.

Wobec cierpienia i doświadczeń dusz był Ojcowsko dobry i starał się wszelkimi sposobami ulżyć, podtrzymać, pocieszyć. Okazywał prawdziwe współczucie, bez żadnych zdawkowych frazesów.

Pragnął, by dusze żyły w pełni życiem wiary, by wiara przenikała wszelkie dziedziny życia. Pokora, wyczucie i ufność były podstawą Jego dyrektyw pracy wymaganej od dusz. Serce Jezusa, Matka Najśw[iętsza] - to były nabożeństwa, których uczył, pogłębiając ich znaczenie i zrozumienie, nie lubił ,licznych modlitewek do wszystkich świętych po kolei”, jak mówił. Nie znosił wszystkiego, co trąciło dewocją. Zachęcał bardzo do pogłębiania wiedzy religijnej, mówiąc, że w tej dziedzinie i inteligencja jest za mało uświadomiona. Wszystko, tak w Jego życiu, jak i w Jego kierownictwie streszczało się do jednego: „Oddać się Jezusowi, żyć dla Jezusa, żyć z Jezusem".

Przy każdyn nieomal pożegnaniu, gdy się odchodziło od Niego powtarzał prośbę: „Proszę się za mnie modlić”. W listach tak samo, czasem w tonie aż nadto pokornym. W 1934 r. pisze z Krynicy: „Jestem jak ten lichy fiakierski koń, któremu potrzeba pod górę przydawać przyprzęgu, więc o ten przyprzęg (modlitwę) nadal proszę". W innym liście nazywa się ,natrętnym żebrakiem" proszącym o modlitwę.

Prostota Arcybiskupa uwydatniała się na każdym kroku i tak ułatwiała z Nim stosunki. Był bardzo mało wymagający dla siebie, Jego osobiste rzeczy były nieomal ubogie, Jego cenna biblioteka mieściła się częściowo na półkach prostych. Po Jego śmierci widziałam małą skrzyneczkę $\mathrm{z}$ dychty ${ }^{139}$, w której układał swe brewiarze i kilka książek podręcznych; było ich zaledwie kilka. Gdy szukano w nich obrazków dla osób, które prosiły o pamiątkę, znaleziono zaledwie kilka i to przeważnie starych.

Kładziono $\mathrm{Mu}$ zawsze na stole zeszyt lub blok, aby miał papier na notatki podręczne, a jak często te notatki lub nawet medytacje były pisane na starych kopertach lub skrawkach papieru. Za to jak chodziło o kult Boży, o katedrę, wówczas chcial, aby wszystko było wspaniałe, naprawdę piękne. Rok przed Jego śmiercią byli we Lwowie dwaj księża z Belgii, którzy studiowali historię sztuki i objeżdżali całą Europę. Zachwyt ich nad katedrą ormiańską nie miał granic wprost. Gdy zostali przedstawieni Ks. Arcybiskupowi, w gorących słowach wyrazili $\mathrm{Mu}$ podziw dla Jego katedry, co Go ogromnie ucieszyło.

Ostatnią wielką pociechą dla Arcybiskupa był telegram od Ojca Św[iętego] otrzymany parę dni przed śmiercią; tak był wdzięczny za te słowa pełne dobroci, obietnicę modlitw oraz błogosławieństwo.

${ }^{199}$ Przestarzałe: dykta. 
W listopadzie bawił we Lwowie, dokąd przybył z Rzymu, znany Redemptorysta Ojciec Schryvers ${ }^{140}$. Arcybiskup znał go i cenil go bardzo, prosil by go odwiedził, gdyż chciał się u niego wyspowiadać. Ojciec Schryvers przybył natychmiast i dhugo bawił u dostojnego chorego. Wychodząc, gdy go pytano jak znalazł Ekscelencję, czy siły dopisały podczas długiej rozmowy, powiedział: „Mais oui'll a pu très bien parler, je ne le trouve pas si mal... et quelle lucidite, quelles limières"|141

Do końca życia Arcybiskup trapił się, że tyle czasu poświęcił dziełu o Teresie Neuman[n] i sprawach mistycznych, z powodu którego miał dużo przykrości. Jednak w końcu przekonał się, że za granicą szczególnie książka ta wywołała duże zainteresowanie i była oceniana dodatnio i rzeczowo. Potem doniesiono Mu o powiedzeniu jednej osoby bardzo dalekiej wszelkiego mistycyzmu, która twierdziła, że ta książka jest bardzo pożyteczna i dużo dobrego zrobiła, gdyż w tych czasach tak zmaterializowanych trzeba ukazać, że istnieje inny świat duchowy. Arcybiskup był $\mathrm{z}$ tego bardzo zadowolony.

\section{e) Ostatnie wizyty u Arcybiskupa Teodorowicza}

Rok 1937 - zima. W słabo oświetlonym dużym salonie Arcybiskup słucha przez radio mowy programowej jednego z czołowych polityków polskich. Jest zasłuchany, widać, że każde słowo waży, czasem okazuje zniecierpliwienie, czasem fala smutku zalewa Jego twarz. Gdy mowa się kończy, wstaje i przechadza się po pokoju zamyślonym, wreszcie zaczyna mówić: „I co z tego wszystkiego wyniknie? To wszystko jest niejasne, a przecież ogólnoświatowe położenie i położenie Polski są bardzo poważne”. Pytam, czy się czego się obawia dla Polski? „Tak obawiam się, nie tylko o Polskę, ale o całą Europę. Dochodzimy do jakiegoś punktu kulminacyjnego, a może raczej staczamy się. Bo proszę wziąć pod uwagę, że nie można bezkarnie deptać wszystkie prawa, jak to się coraz bardziej robi, nie można żyć tylko kompromisami. Nie można wreszcie tolerować zło, pokrywać je, bo wydaje się, że tak będzie lepiej, wygodniej. Nie, nie można i to się mści i mścić będzie. Europa dla spraw ekonomiczno-gospodarczych przyjęła sprawę wschodnią fait accom$p l i^{142}$, to jest wrzód, który ją zgangrenuje. Jakiż jest obecny poziom dyplomacji ogólnoświatowej? Jaka wiedza i poziom moralny tych dyplomatów? Często są to

${ }^{140}$ Właściwie: Schrijvers Joseph (1876-1945), święcenia kapłańskie w Zgromadzeniu oo. Redemptorystów w 1900 r., wykładowca teologii ascetycznej i filozofii w studium zakonnym, w 1913 r, w towarzystwie trzech współbraci podjął pracę duszpasterską na terenie archidiec. lwowskiej obrządku greckokatolickiego na zaproszenie abp. A. Szeptyckiego, z upoważnienia Stolicy Apostolskiej pelnił funkcję wizytatora Zakonu oo. Bazylianów i Zgromadzenia ss. Shużebniczek NMP obrządku unickiego, w 1933 r. został prowincjałem prowincji belgijskiej, powołując zarazem wiceprowincję we Lwowie, w 1938 r. powrócił do Lwowa na uroczystości 25-lecia wiceprowincji, autor licznych prac teologicznych. Zmarł 4 III 1945 r. w Rzymie. A. Deboutte, Schrijvers Joseph, [w:] Dictionnaire de spiritualité ascétique et mistique, vol. 14, Paris 1990 , kol. 445-447; O. Gregorio, Schrijvers Joseph, [w:] Enciclopedia Cattolica, vol. 11, Firenze 1953, kol. 88.

${ }^{141}$ Fr.: ależ tak, mógł on bardzo dobrze mówić, nie uważam, że jest w tak zlym stanie... i co za jasność myśli, co za światło.

${ }^{142}$ Fr.: fakt dokonany, utrudniający powrót do stanu poprzedniego. 
karierowicze lub komisanci, którzy jako tako prowadzą sprawy, a są na usługach ugrupowań finansowych lub też emisariusze poparci przez masonerię. Prawo obecnie coraz bardziej staje się niczym, obchodzi się je bezkarnie. Nienawiść coraz wyraźniej, potężniej wyziera; mamy tu przykład niektórych przemówień niemieckich, a nienawiść do czego doprowadzi? A więc jeżeli widzimy w polityce coraz więcej bezprawia, zanik etyki, nienawiść, do czegóż to doprowadzi? Do nieuniknionego kryzysu lub konfliktu, a to dla Polski z powodu jej położenia będzie fatalne. Nie jesteśmy ani wyrobieni, ani przygotowani dostatecznie. A przede wszystkim, co mnie przeraża w polityce i co już przefiltrowuje się do różnych dziedzin życia to kłamstwo, takie coraz większe zakłamanie, to jad, który się wsącza w dusze i społeczeństwa, jad, który do rozkładu doprowadzi”. Widać było taki ból i taką troskę na twarzy Arcybiskupa, że głęboko przejęta rzekłam: „Niech Pan Bóg nas broni”. Arcybiskup stanął, wyprostował się i rzekł dobitnie: „Pan Bóg będzie pomagał, gdy będziemy żyli wedhug Jego praw i nakazów".

Rok 1938 - listopad. Arcybiskup ciężko zachorował, leży już od kilku tygodni. Korowody ludzi przychodzi się pytać o Jego zdrowie, wszędzie modlą się za Niego. [Dnia - J.W.] 20/XI mogę się z Nim widzieć na chwilkę. Leży w dużym salonie, jakże boleśnie zmieniona ta wyrazista, piękna twarz, ale dobrotliwy uśmiech opromienia ją i wita się bardzo serdecznie. Rozpytuje się o różne osoby i sprawy. Zapytany jak się czuje, odpowiada: „Powaliło mnie, jestem ot jakby taka kłoda i dusza tak samo bez czucia.... ale jak Pan Jezus chce". Przelatuje mi myśl przez głowę, że nie jest On jak ta kłoda, ale raczej jak potężny dąb powalony, bo w tym schorzałym ciele, w którym serce tak boleśnie i szybko kołacze, jest jeszcze jakaś dziwna moc. Ma się wrażenie, że pomimo, iż o tym nie mówi jasno, to jednak wie jaki jest jego stan i poddaje się zupełnie woli Bożej. Chciałby żyć - mówi - by jeszcze pisać o Chrystusie.... ale i to oddaje Panu Jezusowi. Cierpi bardzo fizycznie i moralnie, ale jak cudownie te cierpienia przyjmuje i znosi. Gdy lekarze radzili między sobą, w jaki sposób Mu ulżyć, powiedział: „Nie, nie chcę ulgi, cierpienie to mój skarb". Prosi ciągle o modlitwy, ale nie tylko dla siebie, ale wciąż powtarza, aby modlono się za Papieża, Kościół, Polskę. W chwili [gdy - J.W.] odchodzę, mówi jeszcze: „Proszę przyjść niedługo... jeszcze pomówimy” i daje mi różne polecenia dla osób bliżej z Nim żyjących i klasztoru S[acré] C[oeur].

Listopad 29. Tydzień przed śmiercią, gdy przychodzę do pałacu, mówią mi, że noc była ciężka. Arcybiskup był jakiś niespokojny, długo nie mógł zasnąć. Opowiadają mi, że około 2-ej czy 3-ej w nocy, czuwający brat nagle posłyszał głos Arcybiskupa ale tak silny, że był tym zupełnie zaskoczony, a jeszcze bardziej zdziwił się, gdy ujrzał dostojnego chorego siedzącego na łóżku (od dłuższego czasu nie mógł zupełnie sam się podźwignąć) modlącego się żarliwie, błagającego Pana Jezusa o miłosierdzie dla świata, Kościoła, Papieża, Polski. Trwało to dosyć długo i ogromnie wzruszyło obecnych. Potem leżał długo w milczeniu i cały dzień jest jakiś nieswój, poruszony, małomówny. Brat mówi Mu, że przyszłam, każe mi czekać, potem woła. Wchodzę cichutko i klękam przy łóżku. Zmiana rysów wielka, 
cierpienie wyryło bruzdy na tej biednej wychudzonej twarzy. Uśmiecha się blado: „Jesteś, czekaj”, trochę przymyka oczy jakby się skupiał, potem zaczyna mówić: „Módl się za Kościół, Papieża... błagaj o miłosierdzie dla Polski, módl się zaraz. Powiedz przełożonej (S[acré] C[oeur]), matkom, aby się modliły.... módlcie się za Polskę" - mówi silnym głosem, jakby wszystkie siły wytężał. Patrzy przed siebie $\mathrm{z}$ wyrazem nieopisanego bólu, jakby coś widział.

Mówię po cichu: „Ja się wciąż modlę za Kościół i Ojca Św[iętego], Ekscelencjo”. [Odparł: - J.W.] „Tak wiem, ale teraz się trzeba modlić usilnie, błagać... to straszne... takie straszne czasy idą.... trzeba błagać o miłosierdzie”. Obiecuję, że zaraz poproszę Matkę Przełożoną, aby się modliła wraz z całym zgromadzeniem i dodaję: „Będziemy błagać Pana Jezusa o miłosierdzie”; na słowa „Pana Jezusa” cudny uśmiech opromienia i odpręża twarz Arcybiskupa. „Pan Jezus, Jezus - szepce - tylko On może pomóc". Chwilę leży z oczyma zamkniętymi, potem jeszcze chwilę rozmawiamy, daje polecenia niektóre i błogosławi z jakąś dziwną uroczystością. Prosi o modlitwy podkreślając pokornie, że On ich tak bardzo potrzebuje... zaznacza, że chce tylko spełnić wolę Bożą. I to było ostatnie widzenie z Nim.

Porządkując i odnosząc do gabinetu Jego cały stos korespondencji i papierów, które leżały przy Nim na stole, a które kazał zanieść do swego biurka, znaleziono notatkę z datą 1 stycznia 1938 r., która streszcza jakby program Arcypasterza na nadchodzący rok: „Żyć myślą o wieczności, dla wieczności i wszystko czynić dla chwały Ojca".

\section{f) 5/XII 1938 r. Ostatnie wspomnienie}

Wczoraj wieczorem zmarł J[ego] E[kscelencja] Ks. Arcybiskup Teodorowicz. Rano poszłam do pałacu. W dużym salonie na olbrzymiej kanapie (na której umarł) leżały zwłoki okryte białą kapą. Jakiż spokój i majestat widniały na tej wyrazistej twarzy, którą cierpienia ostatnich miesięcy wyrzeźbiły subtelnie. Można było prawie mieć złudzenie snu, gdy się na Niego patrzało, naokoło nic się nie zmieniło: stoi stół z brewiarzem i różańcem, notatnik, szklanka. Cicho, nie ma nikogo, więc modlę się spokojnie. Wtem ostry dźwięk dzwonnika przerywa ciszę. $Z$ dołu nadlatują głosy młodo-męskie. Wstaję, usuwam się na próg małej jadalni i modlę się dalej, patrząc na profil zmarłego, odcinający się wyraziście na szarej ścianie. Nikt tu mnie nie widzi. Słyszę, że brat perswaduje komuś, że nie można jeszcze zwłok nawiedzać, potem będą wystawione w kaplicy. Ktoś żywo nalega: „Bracie, puśćcie nas, On zawsze nas przyjmował, On taki nasz", widać, że ten argument brat przekonał. „A no, to niech panowie idą do dużego salonu”. Szczęk zbroi, zadźwięczały ostrogi i czterech młodych ułanów stanęło na progu. Podeszli do zmarłego, wpatrując się w dobrze im znane rysy, potem umilkli i ulękli tuż koło Niego, modląc się w skupieniu. Po chwili wstali poszeptali między sobą i nagle stojąc szeregiem wyprężyli się jak struny, „Baczność!” - błysnęły szable. Ułani polscy, żółci ułani oddawali hołd Arcybiskupowi, który tak Polskę i jej armię kochał. Potem zniżyły się 
szable powoli i kolejno dotknęły zwłok Tego, który parę dni przed śmiercią, jakby ostatnim wysiłkiem dobytym ze zbolałego serca mówił do otaczających go: „Módlcie się za Polskę, módlcie się za Polskę". Może przeczuwał, może już wiedział, że wkrótce polska krew się poleje. I jeszcze chwilkę stali młodzi ułani, potem odeszli od Tego, o którym tak słusznie powiedzieli „On taki nasz”.

\section{ARCYBISKUP' TEODOROWICZ}

Dziesięć lat temu, 4 grudnia 1938 r. zmarł jeden z największych kaznodziejów polskich, arcybiskup Józef Teofil Teodorowicz. Zbyt wszechstronna była jego działalność, by można już dziś napisać wyczerpujący życiorys. Zresztą trudna byłaby to praca, gdyż większość materiałów jest w rękach prywatnych albo zaginęła w zawierusze wojennej. Do oceny działalności politycznej i społecznej arcybiskupa Teodorowicza trzeba również pewnej perspektywy czasu i historii. Niemniej należy mu się chociaż krótkie wspomnienie, bo zbyt dużą rolę odegrał w duchowym życiu Polski, aby pamięć o nim miała zginąć.

Mówić o pracach i zasługach arcybiskupa Teodorowicza, to równocześnie omawiać dzieje spøłeczeństwa polskiego na przełomie dwóch wieków, dzieje walki z zaborcami i zmartwychwstanie Ojczyzny. Jeżeli bowiem w tych okresach dokonywały się nieraz zasadnicze przemiany w kierunku dobra, to była to w dużej mierze zasługa także arcybiskupa Teodorowicza.

W czasie ubóstwiania rozumu, w okresie modernizmu, on wskazywał poganiejącemu pokoleniu ideały Chrystusowe. W czasach niewoli krzepił wiarę w nadchodzącą Polskę, podczas wojny umiał dojrzeć bliskie zmartwychwstanie. W okresie powojennym, w okresie użycia i panowania prywaty, tępił nadużycia i głosił etykę Chrystusową. $Z$ miłością wielką i żołnierską odwagą dążył zawsze do jednego celu: do przybliżenia Królestwa Bożego na ziemi. To trzeba mieć stale w pamięci, chcąc go zrozumieć.

Urodził się w roku 1864 ze starej rodziny ormiańskiej, zupełnie jednak zasymilowanej w Polską. Z domu wyniósł głęboką religijność, a patriotyzmu uczył się w literaturze wieszczów. W roku 1887 wyświęcony na kapłana, pracuje kolejno jako wikary, proboszcz, kanonik kapituły, a od roku 1902 dzierży pastorał biskupi. Metropolia ${ }^{143}$ jego obejmowała wszystkich Ormian w monarchii austriackiej, ale duchowa diecezja sięgała granic Polski. Widział go Poznań, słyszała Warszawa. Miał dwa wielkie ukochania: Ojczyznę i dusze polskie. Wszystkimi siłami dążył, by „uwielmożnić Jezusa w duszach i narodzie”. - „Ukształtować, urobić w was Chrystusa Jezusa, wyryć Go w duszach i sercach, ożywić was jego duchem na po-

\footnotetext{
- Maszynopis w objętości 3,5 stronic formatu A 4. Tekst powstał w $1948 \mathrm{r}$.

${ }^{143}$ Błąd autorki; we Lwowie nie było metropolii ormiańskokatolickiej, ale archidiecezja.
} 
dobieństwo Jego, a nie spocząć, dopóty, dopóki jedno z Nim się nie staniecie przez zjednoczenie z Nim - oto moje zadanie"144.

Jako proboszcz i kanonik organizował pracę społeczną, założył drugą z rzędu w zaborze austriackim szkołę dla analfabetek oraz Bractwo Wydawnicze św. Józefa, był twórcą i współredaktorem katolickiego pisma „Przedświt”145.

Jako arcybiskup wytyczył program księżom, zawiązał kongregację ziemianek i uczył je pracy u podstaw i życia wewnętrznego. (Kierownikiem tej Kongregacji pozostał do śmierci). Odnowił wreszcie z wysokim poczuciem piękna starą katedrę. Czujny i rozumiejący przejawy życia zwalczał szerzący się modernizm, teozofię i różne prądy okulistyczne ${ }^{146}$, za co otrzymywał od Pisua XI osobne słowa uznania $\mathrm{w}$ dniu złotego jubileuszu. Ludziom spragnionym głębszego życia religijnego dawał zdrową mistykę katolicką, co na owe czasy było nowością. Był wybitnym członkiem polskiego Episkopatu. „Byłeś jego myślicielem i mózgiem - powie kardynał Hlond ${ }^{147}$ - a kiedy trzeba było dla dobra Kościoła bronić jego autorytetu, Ty byłeś zawsze pierwszy, który zastanawiałeś nie tylko słowy, ale i powagą swego autorytetu, tego autorytetu, co nie błyszczy, ale tym silniej się zaznacza" (z przemowy jubileuszowej).

Jako członek-Rady Szkolnej Krajowej, sejmu galicyjskiego, czy Izby Panów w Wiedniu bronił sprawy polskiej, stojąc na gruncie sprawiedliwości dziejowej, daleki od jednoczenia interesów Polski ze sprawą Niemiec czy Austrii. Wybitny wyraz temu dał w swojej stynnej mowie 30 VI 1917 roku, gdy przypominał zabór Polski i nieprzedawnione prawa narodu do wolności. Gdy referent generalny podniósł zarzuty niewdzięczności Polaków względem Habsburgów, arcyb[iskup] Teodorowicz, jako poseł, na następnym posiedzeniu $30 \mathrm{X}$ tegoż roku wykazał dawne i nowe przewinienia Austrii względem Polaków. Zakończył z siłą: "W słowie «sprawiedliwość» mieszczą się wszystkie sny przyszłości Polaków, wszystkie narodowe programy, w nim jest zaklęta cała tęsknota nasza i nadzieja, a jej postula-

${ }^{144}$ J. Teodorowicz, Na przelomie, s. 274.

${ }^{145}$ „Przedświt” - dziennik katolicki wychodzący w latach 1900-1904 we Lwowie, powołany do życia przez abp. J. Teodorowicza i abp. J. Bilczewskiego. Wydawcą i redaktorem odpowiedzialnym był Mieczysław Dawid Teodorowicz, funkcję redaktora naczelnego pełnil początkowo ks. J. Teodorowicz - ówczesny kanonik Kapituły Katedralnej we Lwowie, później powstał komitet redakcyjny. Współpracownicy: Wlodzimierz Czerkawski, Bronisław Dembiński, Józef Flach, Stanisław Brandowski, Maurycy Madurowicz, Tadeusz Pilat, Zygmunt Sarnecki, Edmund Sas-Naganowski, Krzysztof Mieroszewski, Ludwik Masłowski. AAK, M. Smoleń, „Przedświt” 1900-19004. Monografia dziennika, Kraków 2007, passim, mps. (praca magisterska napisana na seminarium $z$ historii najnowszej pod kierunkiem ks. prof. PAT dr. hab. Józefa Wołczańskiego).

${ }^{146}$ Bląd autorki; powinno być: okultystyczne.

${ }^{147}$ Hlond August (1881-1948), święcenia kapłańskie w 1905 r. w Krakowie w Zgromadzeniu Księży Salezjanów, przełożony klasztorów w Przemyślu i Wiedniu, inspektor prowincji austro-węgierskiej, 1922-1925 administrator apostolski Górnego Śląska, 1925-1926 biskup ordynariusz diec. katowickiej, 19261948 metropolita gnieźnieński i poznański oraz Prymas Polski, w 1927 r. kreowany kardynałem, założyciel Towarzystwa Chrystusowego dla Wychodźctwa, 1939-1945 przebywał w Europie Zachodniej, w 1946 r. mianowany metropolitą warszawskim z zachowaniem arcybiskupstwa w Gnieźnie. Od 1992 r. trwa jego proces beatyfikacyjny. P. Nitecki, Biskupi Kościola, s. 80. 
tem praktycznym jest restytucja"148. (Mowa ta wyszła w broszurce p.t.: ,Z dziejowej chwili"). Niestety, Polacy obecni na sali wcześnie się wycofali i został sam mówca, przywołany przez przewodniczącego do porządku dziennego. Sam uratował honor i godność Polski.

W Polsce odrodzonej otrzymał mandat z ziemi podlaskiej, otworzył wspaniałym kazaniem $^{149}$ Sejm Ustawodawczy i zasiadał w nim aż do uchwalenia konstytucji ${ }^{150}$. Kiedyś historia tego sejmu wykaże, ile dobrego zdziałał arcybiskup swym taktem, doświadczeniem parlamentarnym i tym poglądem szerokim, obejmującym daleką przeszłość. W tym czasie jedzie za granicę, by mówić o Polsce, interweniuje w sprawie prastarego Śląska ${ }^{151}$. Gdy z polecenia Stolicy Apostolskiej oddaje godność senatora $w$ drugim sejmie ${ }^{152}$, nie przestaje odczytami, przemowami, radami walczyć o praworządność, prawa religii i sprawiedliwość w narodzie.

Jako człowiek ujmował wszystkich swą wielką prawością, bezkompromisowością, swą wysoką kulturą duchową, prostotą i pokorą, ale przede wszystkim tą miłością, z jaką się zbliżał tak do prostaczków, jak i wielkich tego świata. Najwięcej jednak czasu i serca poświęcał młodzieży. Umieli to ocenić młodzi i w dniu jubileuszu jeden $z$ nich powiedział: „Twoja postawa wobec świata oświecała nasz rozum i sumienie, słowa Twe w sposób dotąd nieznany otwierają przed nami świat prawdziwej myśli. Nauczyłeś nas odróżniać prawdę Chrystusową od szatańskiego fałszu we wszystkich przejawach życia. Rozpaliłeś w nas zapał wewnętrzny, który umie niszczyć wady duszy, miażdżyć przeszkody zewnętrzne i rozpalać żar Chrystusowego idealizmu" 153 .

Cały urok jego osoby, słowa i działania płyną z zespolenia z Bogiem. „Czyje bowiem serce - pisał w jednym liście - raz zadzwoni na nutę Chrystusową, wszędzie potrafi odnaleźć Chrystusa i w święto, i w dzień zwyczajny, i w kościele, i w pracy, i w cierpieniu, i w życiu prywatnym i publicznym".

Arcybiskup Teodorowicz był niezrównanym kaznodzieją. Już sama jego posągowa postać o wysokim czole mędrca, o oczach przymrużonych, jakby olśnionych blaskiem nieziemskim, fascynowała shuchaczy. Głos metaliczny o wielkiej rozpiętości, o barwie, która wspaniale harmonizowała ze słowem głoszonym, dykcja artystyczna, ale przede wszystkim język, mimo prostoty, tak bogaty w porów-

\footnotetext{
${ }^{148}$ Przytoczony tu fragment nie jest bynajmniej cytatem z przemówienia abp. Teodorowicza, lecz parafrazą ostatniego jego fragmentu. J. Teodorowicz, Z dziejowej chwili, Lwów 1918, s. 66-67.

${ }^{149}$ Mowa nosiła tytuł: Kazanie sejmowe wygloszone $w$ katedrze św. Jana $w$ warszawie $z$ okazji otwarcia pierwszego sejmu polskiego. J. Teodorowicz, Na przelomie, s. 195-204.

${ }^{150}$ Por. przypis 1 niniejszej edycji.

${ }^{151}$ Por. przypis 42 niniejszej edycji.

152 Abp Teodorowicz wszedł do Senatu Rzeczypospolitej 12 XI 1922 r., ale wskutek decyzji Stolicy Apostolskiej zabraniającej kandydowania biskupom do parlamentu złożył mandat 9 II 1923 r. Podobny los spotkał bp. Adama Stefana Sapiehę. S. Wilk, Episkopat Kościola, s. 329-330.

${ }^{153}$ Parafraza przemówienia przedstawiciela młodzieży mgr. Emila Nowowsada podczas uroczystości jubileuszu 50-lecia kapłaństwa abp. Józefa Teodorowicza 29 V 1937 r. w auli Uniwersytetu Jana Kazimierza we Lwowie. 50-lecie kaplaństwa J[ego] E[kscelencji] Ks. Arcybiskupa Józefa Teodorowicza. Przemówienie mgra Emila Nowosada, s. 91-94.
} 
nania, tak piękny, tak spokojny dzięki równowadze wewnętrznej, to wszystko było wspaniałą oprawą dla treści głębokiej, mistycznej, która zapładniała umysł i serce słuchacza, nie pozwalała mu ani na chwilę odejść od tematu i zostawiała trwały ślad w duszy i życiu. Podniósł kaznodziejstwo Polski na wyżyny sztuki. Kazania jego cechowała niezwykła siła i odwaga, mężnie głosił prawdę, choćby była najprzykrzejsza i choćby miała go osamotnić. Walczył za Chrystusa i dla Niego. Docierał do głębi sumień, gdyż był wielkim psychologiem, wstrząsał nimi, ukazywał źródło złego, dla innych niedostrzeżone. $Z$ jakimż bólem mówił o obojętności religijnej i dwulicowości w życiu. Ale cały żar występował dopiero, gdy mówił o Chrystusie Panu, wnikliwie analizując Jego osobowość i życie.

Płomieniem swej duszy zapalał serca słuchaczy, treścią i stylem przykuwał uwagę, porywał wyobraźnię, myśl głęboka była strawą dla rozumu, a namaszczenie nadprzyrodzone pobudzało do czynu religijnego dla Chrystusa, w Chrystusie i z Chrystusem. Tajemnica jego wpływu leżała w tym, że umiał uchwycić rytm życia współczesnego i znał psychikę zbiorowości. Społeczeństwo czekało na jego słowo, było mu wdzięczne za prawdę, ale przede wszystkim za miłość. W pierwszym liście swym pasterskim pisał: „Kocham społeczeństwo miłością kapłana, który miłuje nieśmiertelne dusze, szuka ich i pragnie. Kocham miłością obywatela, w którego sercu znajduje żywy oddźwięk każda radość, każdy smutek, każda nadzieja i zawód społeczny. Kocham społeczeństwo, jak się kocha przyjaciela, którego się bierze jakim jest, $z$ jego niedoskonałościami i ułomnościami, kocham je, jak się kocha ojczyznę".

Część kazań w rękopisie zabrano w czasie wojny do Ossolineum ${ }^{154}$, część pozostaje w rękach prywatnych, część została jedynie w pamięci i sercach słuchaczy, a tylko niektóre wyszły drukiem w luźnych broszurach i w zbiorze „Na przełomie” (Poznań 1923). O tym zbiorze dwukrotnie pisał ks. Nikodem Cieszyński. „W kazaniach tych - mówi między innymi - są wartości siły twórczej, jest głęboka myśl, wspaniałą przywdziana szatą językową, jest polot poetycki i natchnienie. Autor objawia się w nich jako historiozof, nie spuszczając $\mathrm{z}$ oka realnych nizin współczesnej polityki. Ta mądrość przypina skrzydła, kiedy wzbija się na szczyty wiecznego tchnienia. Jak drugi Skarga przewidział i przepowiedział najbliższą przyszłość narodowi"155.

Dzięki tym kazaniom i pracom literackim wszedł do historii kultury i literatury polskiej. Od chwili wyświęcenia pracował nad życiem Chrystusa Pana, zebrał bardzo bogatą literaturę, jeździł 1913 roku do Ziemi Świętej, pisał i bezustannie poprawiał. Niestety, wydał zaledwie trzy tomy: „Od Betlejem do Nazaretu” (Poznań, 1932), „Od Jahwe do Mesjasza” (1936) i „Herold Chrystusa na tle epoki” (1937), IV tom gotowy, czeka na wydanie, a do innych jest zebrany bogaty materiał i liczne refleksje autora, refleksje znaczone miejscami błyskami geniuszu.

${ }^{154}$ Mowa o Zakładzie Narodowym im. Ossolińskich we Lwowie, w którym podczas II wojny światowej wiele polskich instytucji oraz osób prywatnych deponowało swoje zbiory.

${ }_{155}$ N. Cieszyński, rec.: J. Teodorowicz, Na przelomie. Przemówienia i kazania narodowe (Poznań 1923), „Przegląd Homiletyczny”, 1(1923), s. 303-306. 
O pracy tej pisał niedawno ks. profesor $\operatorname{Stach}^{156}$ w „Ateneum Kapłańskim”157, podziwiając sumienność autora, miłość przedmiotu, niezrównany zmysł syntezy wiążący historyczne fakty $z$ aktualnymi zagadnieniami. Tomy te wywarly wielkie wrażenie i w świecie naukowym i wśród publiczności żądnej poważnej strawy religijnej. Świadczą o tym recenzje i liczna korespondencja.

Równocześnie spisywał medytacje na tle Ewangelii, które wyszły w dwóch tomikach: „Mnie żyć jest Chrystus” (Poznań 1919) i „Okruchy ewangeliczne” (1922). W tych rozważaniach autor zrywa ze sztywnym szablonem. Są to bezpośrednie wołania duszy olśnionej wielkością miłości Chrystusowej. Autorowi chodziło nie o pojedyncze cnoty, ale o mistyczny stosunek z Jezusem Chrystusem, stosunek, którego emanacją dopiero są cnoty. Rok temu OO. Karmelici wydali tomik medytacji: ,Z Jezusem Chrystusem" ${ }^{158}$, pisanych w ostatnich latach przed śmiercią. Odsłaniają nam one tajemnice duszy autora, uczą bezpośredniej modlitwy, a ks. Żychliński powiedział o nich, że są ,perłami polskiej literatury duchowej” (słowo wstępne).

Kilka lat przed końcem swego pracowitego życia zajął się arcybiskup studiowaniem stanów mistycznych w związku z przeżyciami Teresy Neuman[n], którą kilkakrotnie odwiedzał w Kennersreuth. Owocem tych studiów są dwie obszerne prace: w języku polskim ,Zjawiska mistyczne i ich tłumaczenia" (Poznań 1933) i „Kennersreuth im Lichte der Mistyk und Psychologie” (1936). Uważał za swój obowiązek stanąć w obronie zasad mistycznych, gdy chodzi o naukowe badanie takich objawów, jak u Teresy. Ks. arcybiskup bał się, by racjonalizm, któremu hołdować zaczęły niektóre fakultety $\mathrm{w}$ dziedzinie egzegezy, nie zapanował bezwzględnie w badaniu stanów nadzwyczajnych, gdzie muszą być nawet i w badaniach uwzględniane łaska i charyzmaty Ducha Świętego.

Niemiecka praca bardzo źródłowa wykazała głęboką wiedzę autora w dziedzinie mistyki i żałować należy, że śmierć nie pozwoliła mu przetłumaczyć jej na język ojczysty, jak to zamierzał uczynić. Że autor miał rację pisząc o tych rzeczach, dowodziły liczne recenzje w pismach zagranicznych i pełne szczerego wynurzenia listy. Jeden $\mathrm{z}$ nich od osoby $\mathrm{z}$ dala stojącej od wszelkich mistycyzmów, mówi:

${ }^{156}$ Stach Piotr (1886-1961), święcenia kapłańskie w 1911 r. w Tarnowie, VIIl-X 1911 r. wikariusz par. Zassów, 1911-1914 studia biblijne w Rzymie uwieńczone stopniem lektora, 1914-1915 wikariusz par. Trzciana k. Bochni, 1915-1919 wikariusz katedralny w Tarnowie, w 1917 r., uzyskal doktorat teologii na Wydziale Teologicznym UJ, 1919-1939 profesor Nowego Testamentu na Wydziale Teologicznym Uniwersytetu Jana Kazimierza we Lwowie, w 1920 r. uzyskał tamże habilitację, 1924/25 i 1930-1933 dziekan fakultetu, 1938/39 i 1939/40 prorektor uczelni, 1922-1923 wicerektor Seminarium Duchownego we Lwowie, 19391950 przebywal w Ujanowicach (diec. tarnowska) okresowo wykładając biblistykę w Seminarium Duchownym w Tarnowie, 1950-1953 profesor Nowego Testamentu na Wydziale Teologicznym UJ, 1953-1961 emerytura. Zmarł 19 VI 1961 r. w Nowym Sączu. J Wołczański, Wydziat Teologiczny, s. 207.

${ }_{157}$ P. Stach, Arcybiskupa Teodorowicza działalność na polu biblijnym, „Ateneum kapłańskie”, 39(1947), t. 47 , s. 449-456; t. 48 , s. $77-82,182-184$.

${ }^{158}$ Właściwie: $Z$ Chrystusem Jezusem. Rozważania. Por. przypis 83 niniejszej edycji. 
„Książka Ekscelencji zrobiła dużo dobrego, gdyż w tych czasach zmaterializowanych trzeba wykazać, że istnieje inny świat duchowy".

Należy jeszcze dotknąć działalności najmniej uchwytnej dla biografa: kierownictwa duszami. W tej dziedzinie miał arcypasterz wyjątkowe światło i laski, co nie zdziwi tych, którzy znali jego ducha modlitwy i widzieli go na adoracji lub przy Ofierze Mszy św. Przede wszystkim śledził działanie Ducha św. w duszy, był bardzo dyskretny i delikatny, nikogo nie przynaglał, tylko imieniem Chrystusa Pana prosił niejako pragnąc, by jak najwięcej dusz oddawało $\mathrm{Mu}$ się zupełnie. Był stróżem praw Jezusowych w duszach. Jako wytrawny psycholog umiał dojrzeć najsłabsze nawet odruchy egoizmu i wypowiadał im walkę. Nie znosił tego, co trąciło dewocją, całe jego kierownictwo streszczało się w jednym: oddać się Jezusowi i żyć w Nim i dla Niego. W jednej swej medytacji arcybiskup zanotował: „Nadprzyrodzony cel życia, to żyć na to i tak długo, jak długo potrzeba, ażeby doczekać się pełni życia wewnętrznego, do jakiego łaska Jezusa mnie wezwała, aby doczekać się chwili, gdy w pełni we mnie żyć będzie Jezus".

Ta chwila przyszła i dla niego. Od kilku lat trwająca choroba przybrała na sile w jesieni 1938 r. i po dwóch miesiącach doprowadziła do katastrofy. W chorobie był tak wielki, jak w całym życiu, zgodzony z wolą Bożą, nie szukający ulgi. „Cierpienie to mój skarb - powie - nie oddam mojej porcji nikomu”. Wciąż się modlił, przeważnie za Polskę i Kościół święty. „Módlcie się za Polskę, bo straszne czasy nadchodzą" - mówił do odwiedzających go. Czyż widział proroczo gehennę hitlerowską? Gdy jedna osoba raz pocieszała arcypasterza, że Bóg nas nie opuści, z siłą powiedział: „Pan Bóg będzie pomagał, gdy my będziemy żyli wedle Jego praw i nakazów".

Dnia 4 grudnia otrzymał ostatnie oleje święte i zupełnie przytomnie odszedł nad wieczorem do Pana, którego tak umiłował. Śmierć jego odbiła się bolesnym echem w całej Polsce, a pogrzeb był wspaniałą manifestacją społeczeństwa, które rozumiało, że traci w nim wielki umysł, gorące serce wielkiego bojownika o sprawę Bożą i narodową. 